التمكن الإداري:مدخل لرفع كفاءة الأداء في مدارس التعليه العام في مصر (دراسة مدانة) أ.م.د/ عد السلام الشرواوي عباس

التمكين الإداري : ملخل لرفع كثاعة الأداء في مدارس التمليم المام في مصر

( دراسة ميداثية )

إعـلداد

أ ـ م ـ د / عبد السلام الشبراوي عباس

كلية التربية ببورسميد

قسم التربية المقارنة والإدارةالتعليمية

مجلة كلية التربية - جامعة بورسعيد

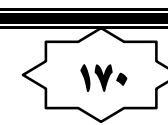

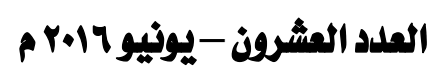




\section{المعود الأولى}

\section{(الإطارالمام للدراسة (2)}

\section{مقدمة اللدراسة :}

تمثل سرعة التغيرات التي تفرض نفسها على عالم اليوم أهم أسباب التعقيد والتشـابك التي يتسم بها واقعنا المعاصر ، وهذا بدوره يفرض تحديات من أهمها ، حتمية الاتجاه نحو المؤسساتية والتقليل

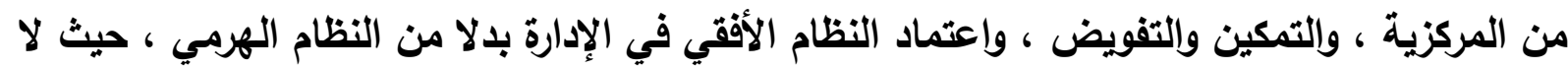

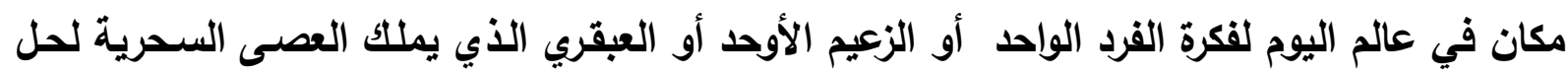

جميع المشكلات .

فالتطورات المتنوعة والمتلاحقة في كافة المجالات المعرفية والتكنولوجية والحضارية والثثافية ،

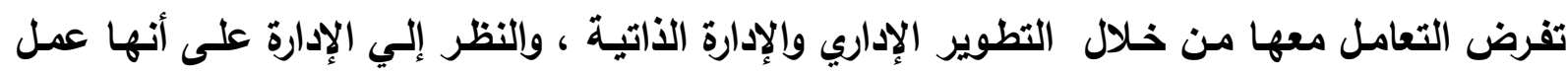

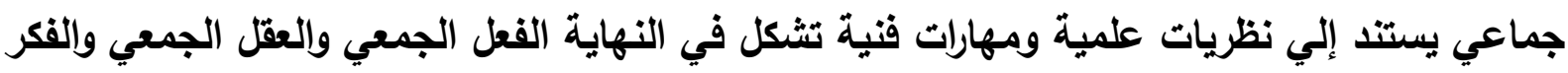

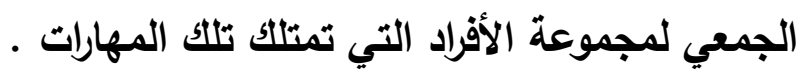
وحقيقة الأمر أن التمكين الإداري أصبح في ظل تعاظم فكرة المشـاركة ، والعفل بروح الفريق

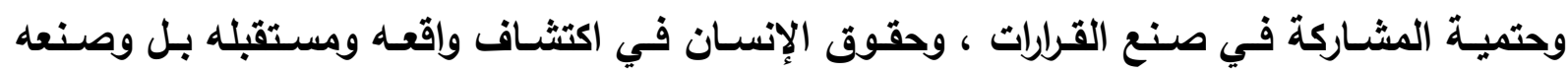

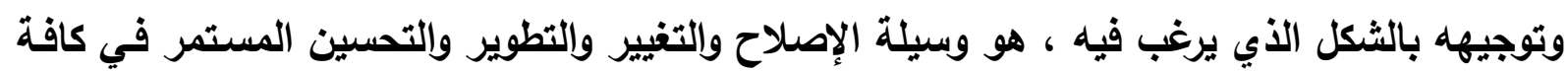

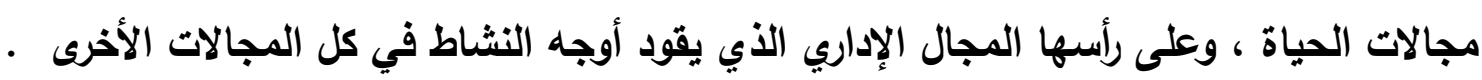

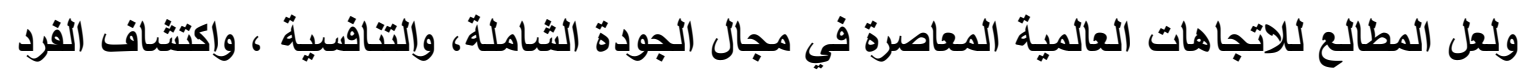

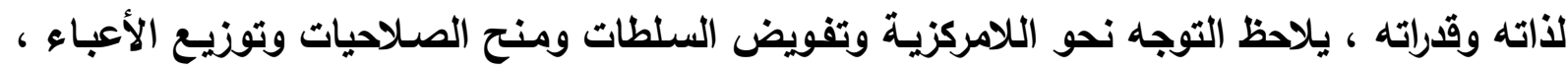

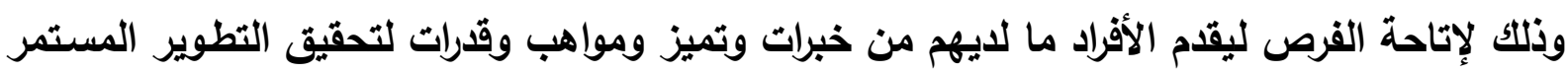

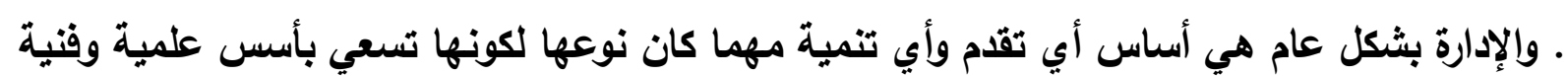

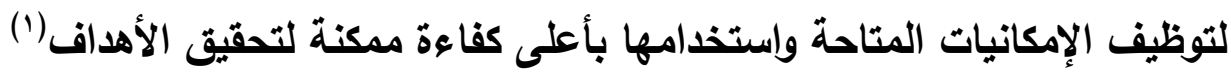

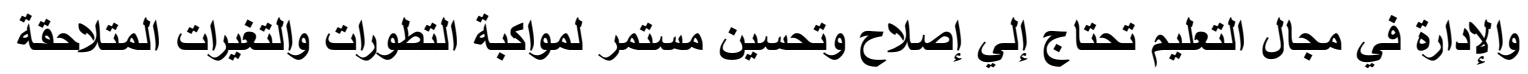

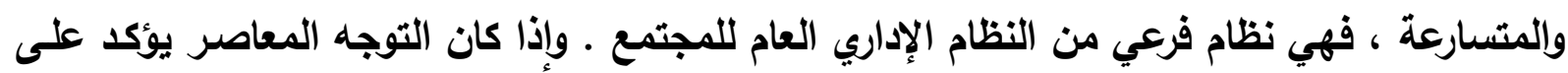

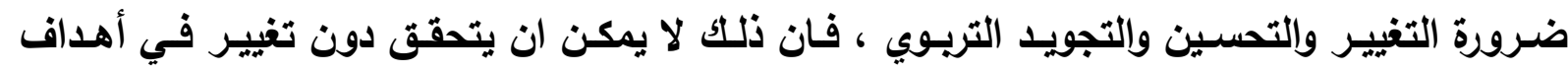

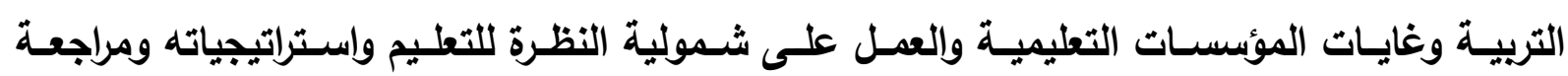

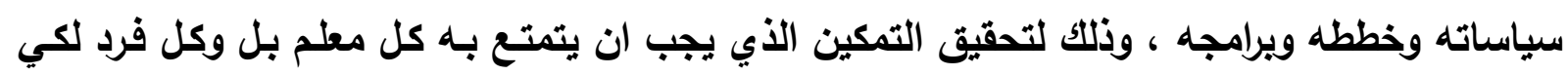

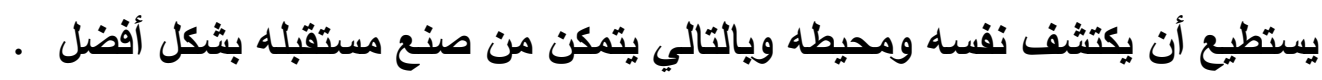

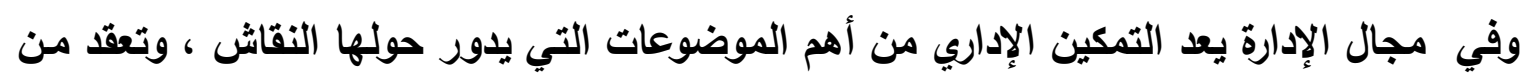

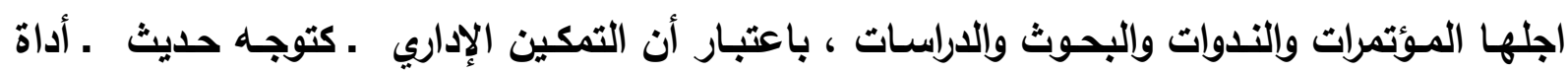

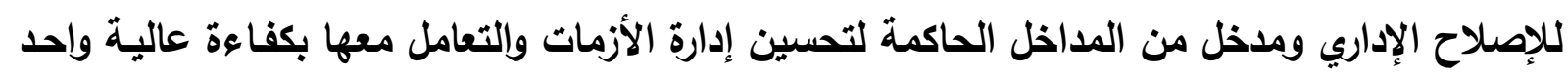




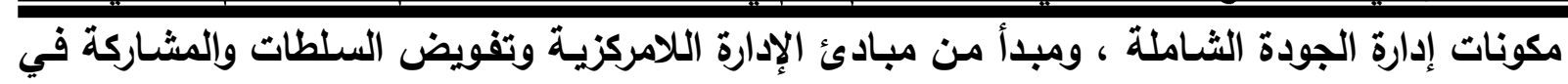

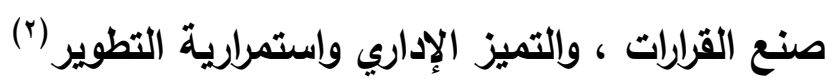
وفي الإدارة التعليمية يعد التمكين الإداري من أهم ركائز التطوير لمنظومة التعليم. وعملية التمكين الإداري إذا تتحقق بشكل واسع فان ذلك يؤدي إلي تحقق أهداف التعليم من تطوير وتحسين وتوسيع

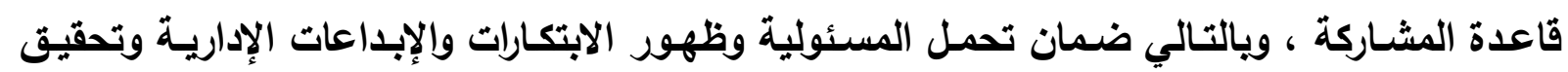
الرضا الوظيفي والانتماء داخل منظومـة التعليم.والتمكين الإداري يعد المدخل الحديث الذي يجمـع بين الأسـاليب المختلفة مـن اللامركزيـة والجودة الثـاملة والتفويض وتخصيص العمل والتـدريب والتمهين والمشاركة في صنع القرار،كما انه يمثل إستراتيجية إداريـة لها كيانها وحقوقها الخاصـة وذلك لتتحول

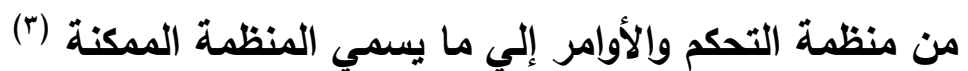
والمشـكلة هنـا تتضـح في مدي تحويل منظومـة التعليم إلـي منظومـة ممكنـة تستطيع كل حلقـات الإدارة المشاركة في صياغة الروئة التعليمية وصناعة السياسة التعليمية وتحديد الاستراتيجيات التلازمة لانجاز الأهداف وتحقيق التطوير المنشود من خلال تحديد البرامج والفاعليات المختلفة . لذا يعد هذا التحدي من أهم التحديات التي تقف عقبـة في تحديث المجتمع المصري وتحقيث الانتماء والمشاركة الفعالة وذلك من خـلال تشرب قطاعات المجتمع المختلفة لثقافة التمكين وخاصـة في قطاع التعليم ، وذلك لان التعليم إذا استطاع أن يشكل مدخلاته وفق هذه الثقافة ويزرع في هذه المدخلات روح الفريق والمشاركة والمسئولية فان هذه المدخلات تتحول إلي مخرجات تحقق التمكين في كافة قطاعات المجتمع بما فيها الإدارة العليا والقائمين على الأمور في كل قطاعات المجتمع . لذلك جـاعت الدراسـة الراهنة للتعرف على واقع التمكين في مدارس التعليم العام بمصر وإبراز معوقاته وذلك كمحاولة للتشخيص و تقديم بعض المقترحات لمواجهة الواقع المأزوم وتحقيق التفعيل المحتوم الأي تمليه متغيرات العصر •

\section{:}

هناك قناعة بان نجاح أو فشل المجتمع البشري إنما يعود إلي نجاح أو فشل الإدارة، ومدي قدرة الإدارة على تحقيت التفـاهم بين أبنـاء المجتمع البشـري حيث إذا تـم ذلك مـن خـلال التفـاهم الدولي تتحصر الحروب والصراعات ، ويتحقق النمو والازدهار على المستوي الدولي • وعند النظر إلي نظام التعليم المصري يلاحظ أن ما يعانيه من مشكلات ، إنما يعود بشكل كبيز إلسي القصور الإداري والعجز والتكلس والتمسك بالمركزية القاتلة للإبداع ، والتي تؤكد على البيروقراطية العقيمة والتي بدورها تحول

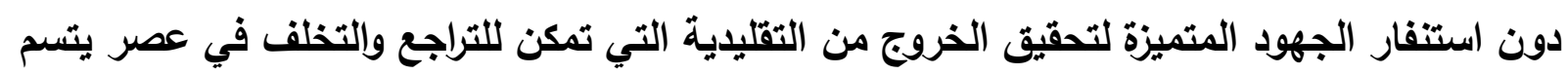
بسرعة التغيير وشدة التعقبد وإلتشبيك ـ مما يفرض إعادة النظر في النظم الإداريـة والأسـاليب القديمة وتجاوزها إلي التوجه نحو اللامركزية والتشـابكية للوصول إلـي تحقيق التنافسية وإطلاق الطاقات لدي كل فرد إذ أن المشـاركة في صـناعة القرار تحقق الـولاء والانتمـاء وزيـادة الإنتاجية وتتميـة الإبـاع 


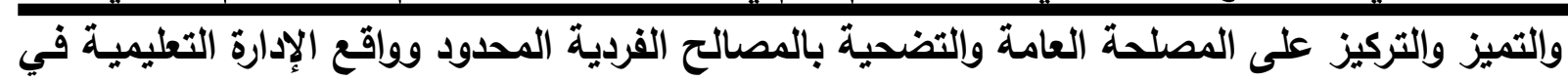
التعليم قبل الجامعي يعكس مدي التمكين لمديري المدارس والمعلمين والعاملين في المستويات الإداريـة داخل المؤسسات التعليمية ـ ويمكن القول إنتا في حاجة ماسة إلي مواجهة المعوقات التي تحول دون هذا التمكين الإداري الذي أصبح ضرورة وجود وضرورة إصلاح وتحسين ويمكن تحديد مشكلة الدراسة الراهنة في التساؤل الرئيسي التاليـي : كيف يمكن تحقيق التمكين الإداري في مدارس التعليم العام في مصر لرفع كفاءة الأداء ؟ ويتفرع من التساؤل الرئيسي السايق مجموعة من التساؤلات الفرعية هي : [1] ما مفهوم التمكين الإداري ؟ وما أسسه ؟ وما عناصره وما أهميته ، وما مبرراته ؟

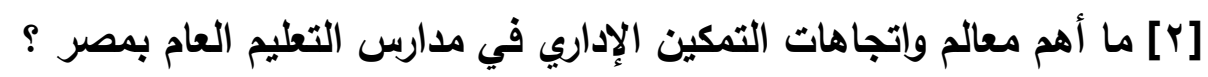

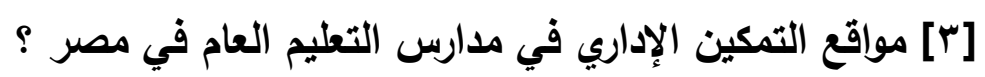

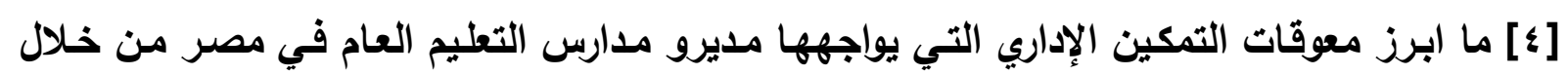
آرائهم ؟ [0] ما أهم المقترحات التي يمكن عن طريقها إزالة معوقات التمكين الإداري في مدارس التعليم العام في مصر ؟

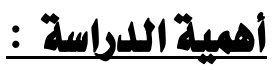

تبرز أهمية أي دراسة من أهمية الموضوع الأي تتصدي له، ولما كان التمكين الإداري في مدارس التعليم العـام في مصر هو موضـوع الدراسـة الراهنـة ، فـان التمكين الإداري مـن الاتجاهـات الحديثة

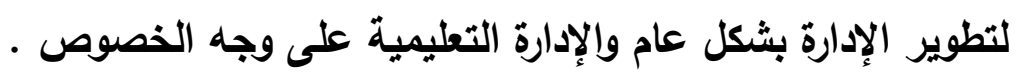
ويالرغم من الجهود المبذولة لتحقيق التطوير الإداري وتثجيع الابتكار وإطلاق الطاقات والكفاعات، فإن الواقع يشير إلي ضعف تأثير تلك الجهود ، حيث المركزية والبيروقراطية مازالت يكرس لها في كثير من الممارسات الفعلية ، كما أن هنـاك معانـاة حقيقية من الالتزام الحرفي والثكلي بـاللوائح والقوانين والقرارات المفروضـة من الجهات الأعلى ، دون مراعاة لروح تلك القوانين والهدف منها ـ لذلك فان الحاجة ماسة إلي تحقيق وتفعيل التمكين الإداري في المستوي الأوسط والمستوي التنفيذي في التعليم وذللك لان هذا التمكين يعد المدخل الأهم لمعالجة المشكلات التي يعاني منها التعليم بعامة وإدارته على وجه الخصوص • وتحاول الدراسة الكثف عن واقع التمكين الإداري في مدارس التعليم العام في مصر والكثف عن المعوقات التي تحول دون تحقيقه في هذا المستوي الهام من هذه المستويات التعليمية

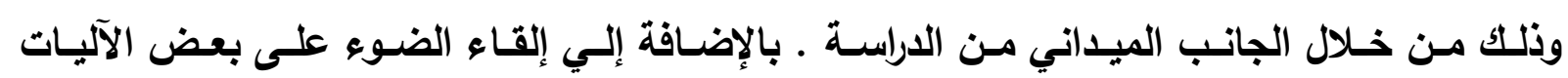

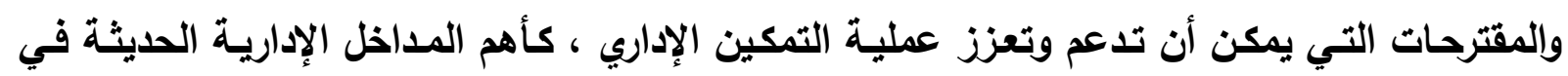

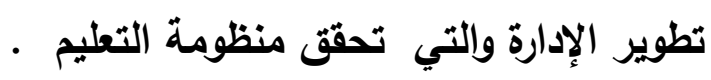


التمكن الإداري:مدخل لرفع كفاءة الأداء في مدارس التعليم العام في مصر (دراسة ميدانة) أ.م.د/ عبد السلام الشبراوي عباس

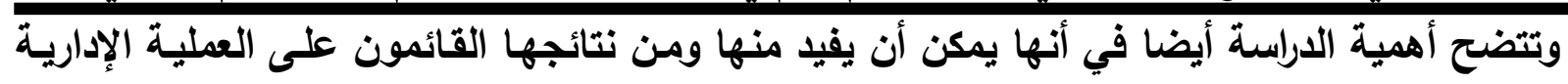

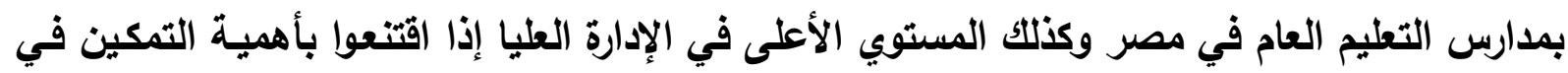

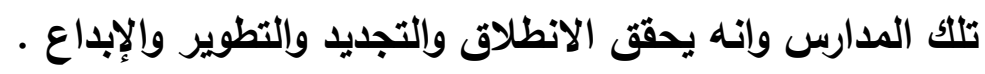

\section{أهداف الدراسة :}

تهزف الاراسة إلي تحقيق الأهداف التالية : [1] التعرف على التمكين الإداري من حيث مفهومه وأبعاده وأسسه ومبرراته وأنواعه الأسئ

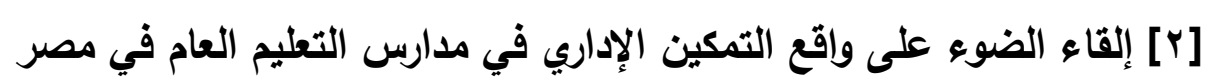

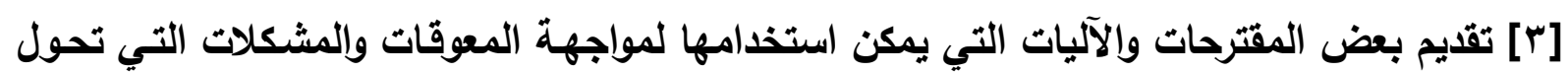
دون التمكين الإداري.

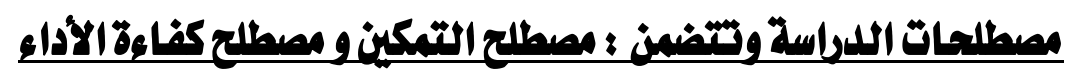

\section{التمكين empowerment :}

من الناحية اللغوية جاء في المعجم الوسيط ( ؛ ) " مكن " أي جعل لله عليه سلطانا وقدرة ـ وفي

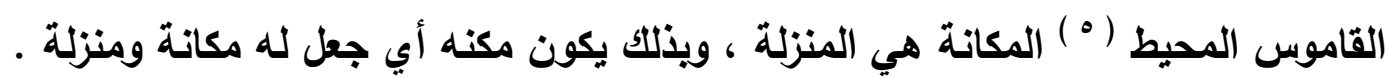

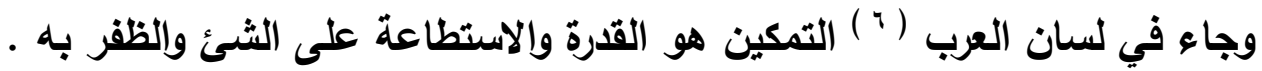

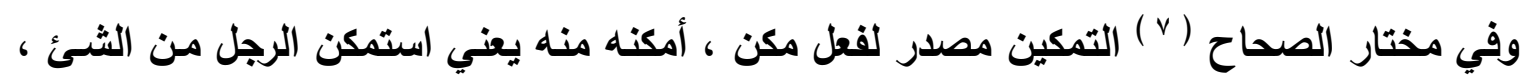

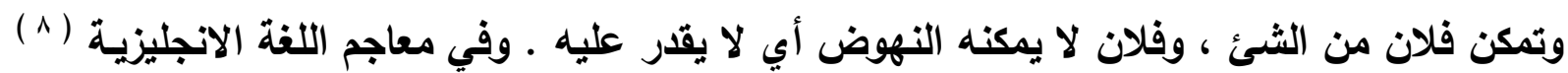
empower

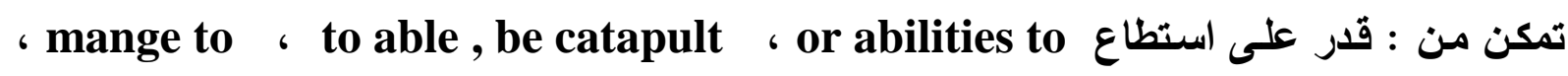
بنفس المعني • ويذلك يمكن القول أن معني كلمة تمكين في اللغة العربية وفي اللغة الانجليزيـة يدور

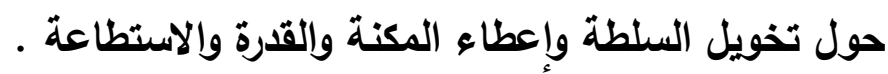

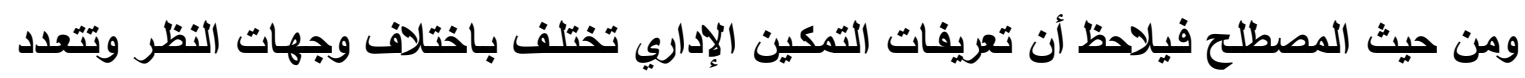

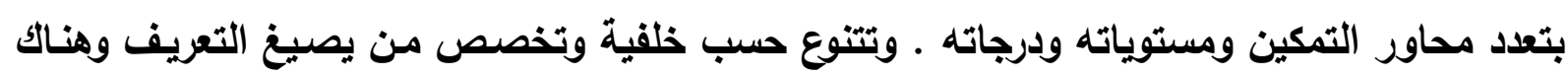

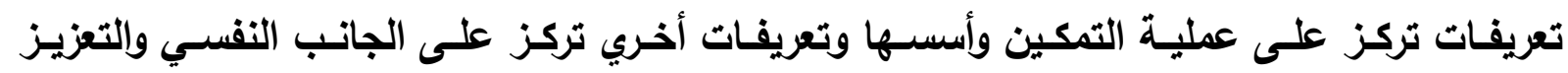

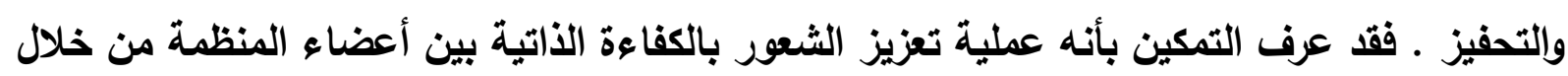

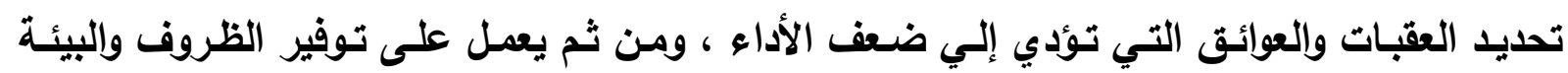

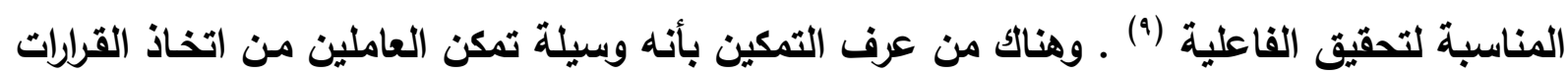

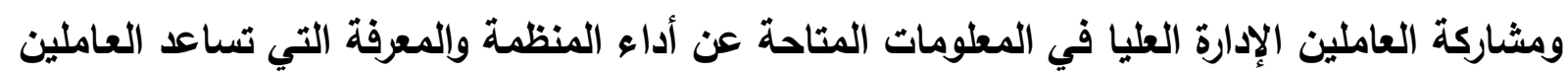

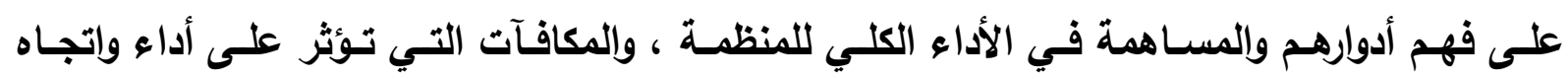

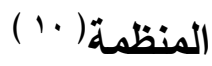
وحول التعريفات السابقة يصبح التمكين = القوة × المعلومات × المعرفة × المكافآت 


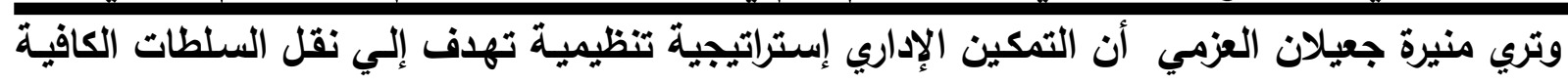

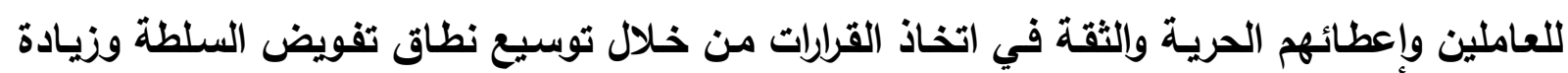

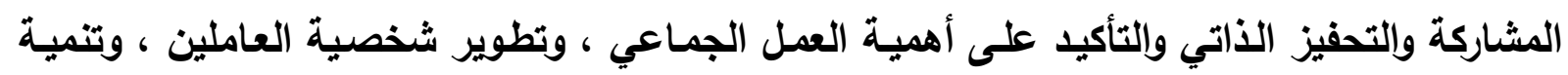

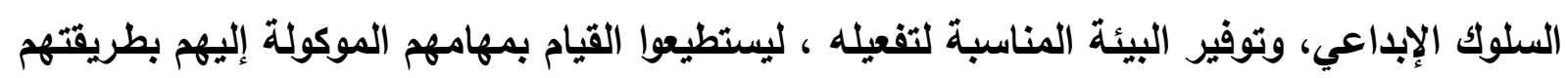
الخاصة دون تلخل مباشر من الإدارة العليا (1') وقد أوردت منيرة جعيلان أن التمكين الإداري في القطاع العام يعني أن تكون القوة والنيا السلطة في

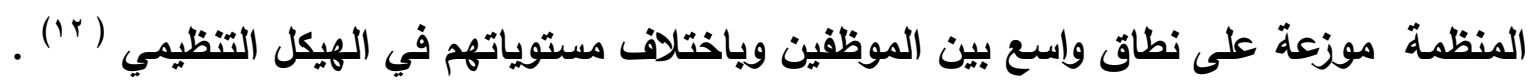

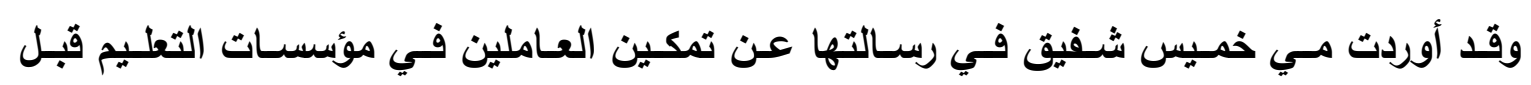

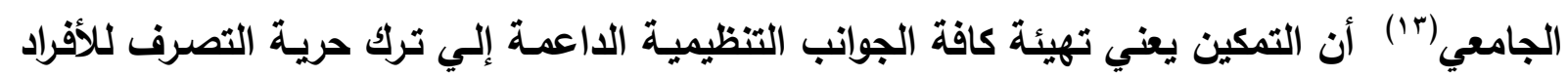
العاملين خاصة المناخ التنظيمي الصحي الذي يكفل وجود ثقة تنظيمية تعزز من ثقائة الأفراد بقدراتهم

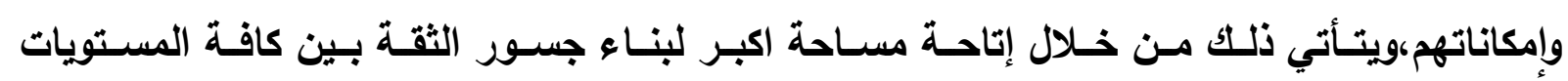
الإدارية(؛) ) ـ وأضافت مي خميس أن Shack letor عرف فلسفة التمكين على أنها إتاحة المزيد

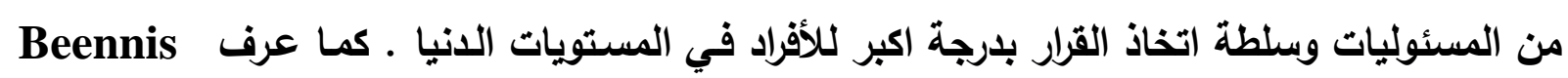

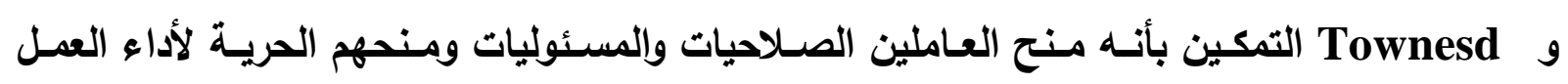

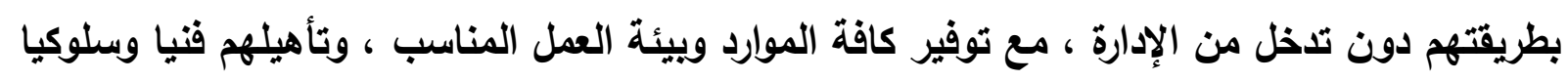

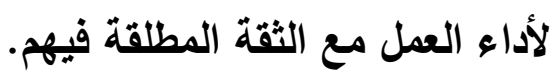
وقد تبنت مي خميس في دراستها التعريف السابق ، لأنها رأت انه تعريف جامعا شاملا حيث شمل من وجهة نظرها توافر كافة الموارد في بيئة العمل والمرتكزات التي يقوم عليها التمكين ، والتأهيل الفني

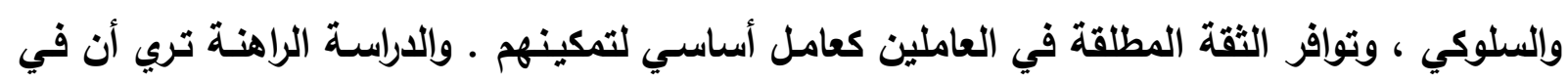
هذا مبالغة إذ أن الوصول لتعريف مانع جامع شامل ومطلق هو أمر صعب في مجال العلوم الإنسانية

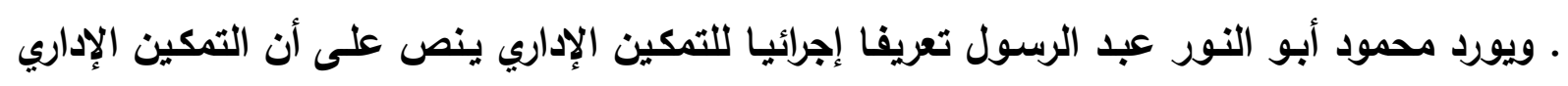

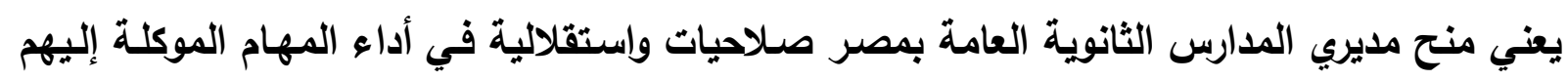

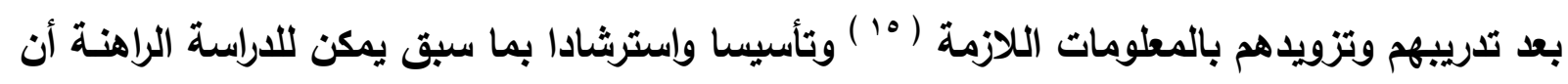
تضع التعريف التالي للتمكين الإداري بمدارس التعليم العام في مصر بأنها هو العملية التي تؤدي إلى التي

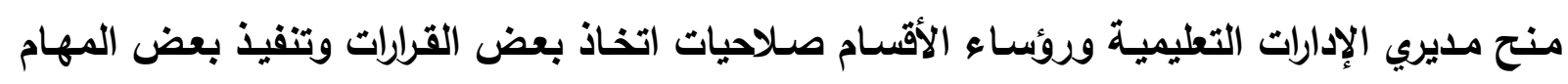

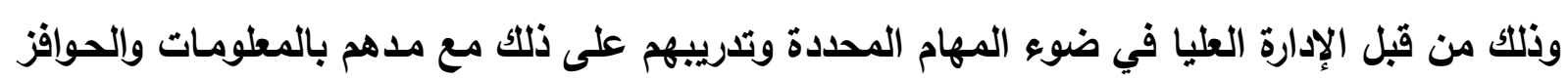

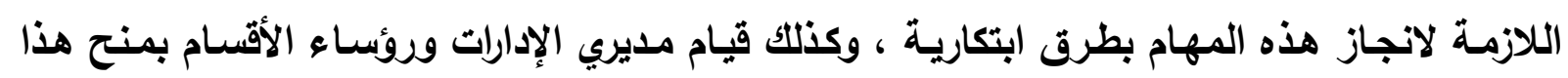

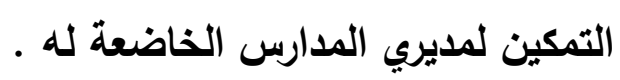


الكفايـة في العربيـة تعنـي التمـام والوفاء بـالكم الـلازم كمـا تعنـي كلمـة كفاءة التناسب ومصطلح

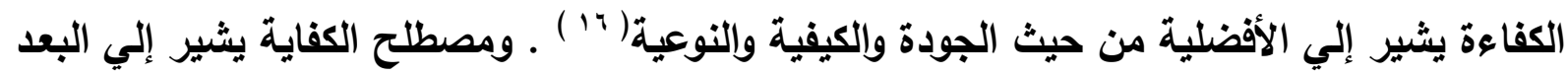

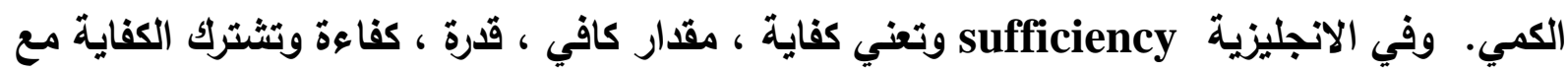

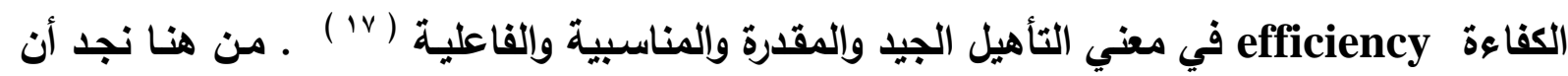
المغنى اللغوي يدور حول الأفضلية والمرغوب فيه من حيث النوع والكم والكيف. وعن كفاءة الأداء

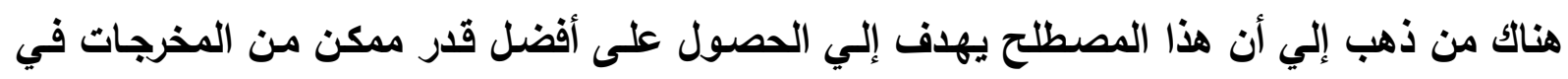

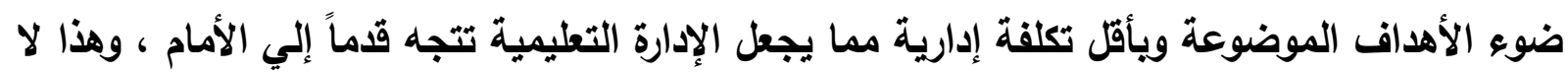

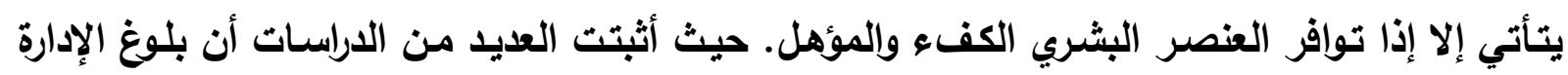

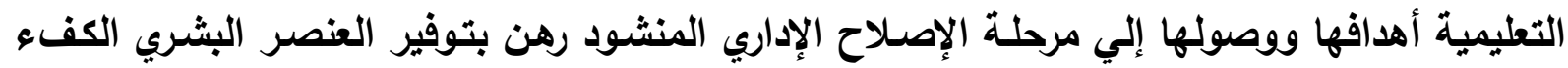

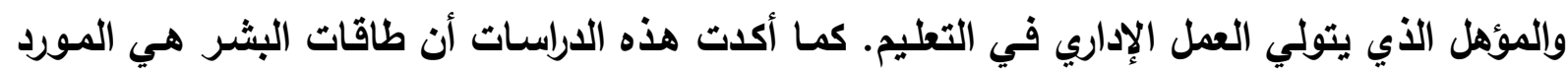

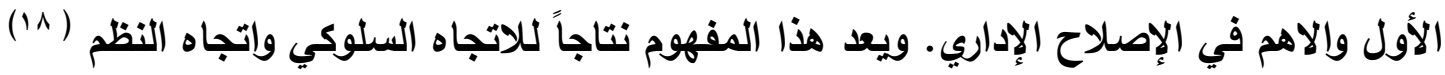
ب - الأبداء

في العربيـة يعني الإتيان بفعل أو سلوك أو دفع بشـئ أو عمل شـئ مـا (19 ). وفي الانجليزيـة

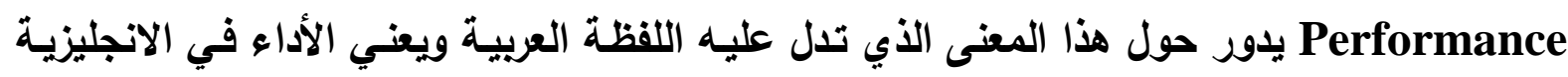

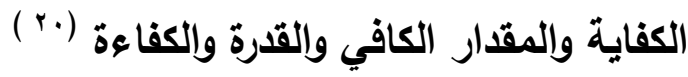
منهج الدراسية :

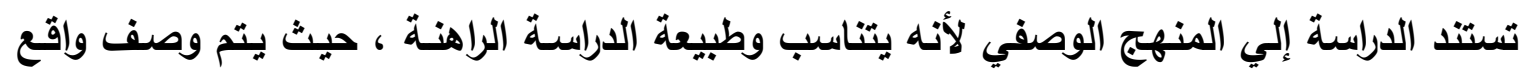
التمكين الإداري في الإدارة الوسطي ، وتحليل هذا الواقع من خلال استجابات عينة الاراسة حول أرائهم عن ممارستهم لعملية التمكين ومدي إتاحة التمكين لهم من جهة الإدارة العليا ومدي إتاحتهم التمكين

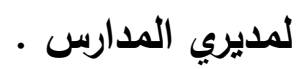
أدوات الدراسة وقت استخدمت الدراسة أدوات منها: أ- المقابلة الثخصية: حيث قام الباحث بعقد مقابلات مـع بعض مديري الإدارات التعليمية وذلك من

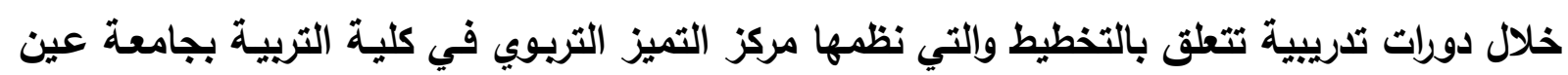

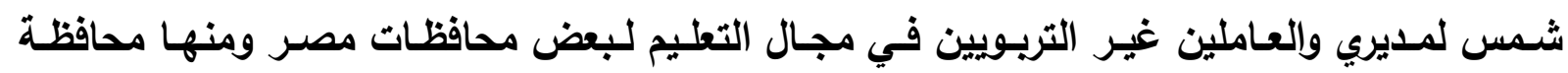

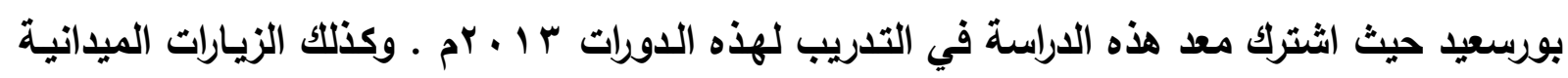

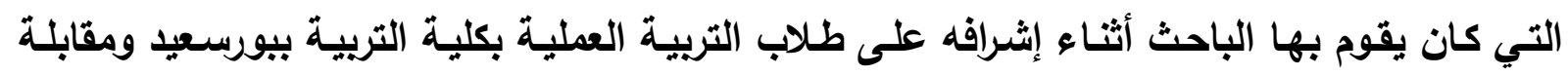
بعض مديري المدارس. 


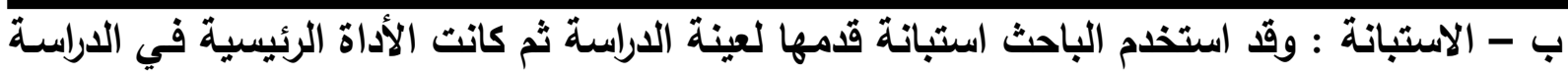
الراهنة هي الاستبانة . الباته

\section{الددراسات السيارقة}

من المعروف أن الدراسات السابقة في أي مجال تعد من الركائز الأساسية والمنطلقات المنطقيـة لأي دراسة لاحقة ـ وتوظف الدراسات السابقة في معالجة الاراسـات اللاحقة في كافة محاورها وينيتها النظرية والتطبيقية والعملية وكذلك النتائج والمبررات التي تستتد إليها تلك الدراسات ـ وهذا ما حدث في الاراسة الراهنة ـ ويمكن تقسيم الدراسات التي استتدت إليها الدراسة الراهنة إلي :

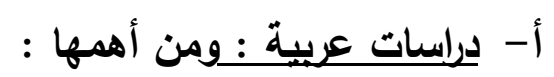

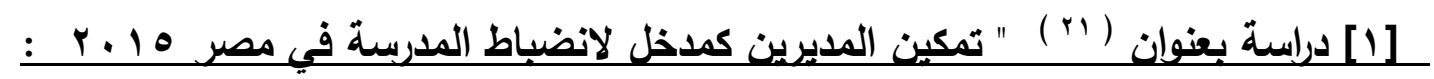
وقد استخدم الباحث في دراسته مـا أطلق عليه منهج دراسـة الحالة في إطار المنهج الوصفي ، واستخدم الاستبانة أداة للاراسـة ـ وقدم الباحث معالجة نظريـة جيدة للتمكين وحلل الاستبانة وخرج بعديد من النتائج كان من أبرزها أن الإدارة العليا لا تسمح لمديري المدارس الثانوية العامة بوضع خطة متكاملة لممارسة الأنشطة الطلابية ، ولا صلاحيات تنفيذ العاملين ، ولا توفر كافة البيانات والمعلومـات عن كافـة أفراد المدرسـة ، ولا تـوفر وسـائل الاتصـال الفعالـة والمتطورة ، ولا توجد ثقة بـين مـيري المدارس ومرؤوسيهم ، ولا تدعم الإدارة العليا تدعيم فرق العمل داخل المدارس ـ وقد أوضحت الدراسـة ضرورة وضع خطة متكاملة ومعلة لتدريب المديرين والمعلين في مجال التمكين الإداري والانضباط

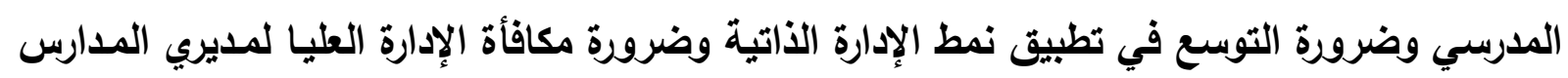
ماديـا ومعنويـا وتوفير وسـائل فعالـة للاتصـال وتوفير قاعدة بيانـات ومعلومـات كافيـة ومتطورة ودعم أسلوب فرق العمل ونشـر ثقافـة التمكين الإداري وتفعيل القرارات الصـادرة في هذا الشــأن من خـلال المتابعة المستمرة للتنفيذ [Y] دراسة بعنوان ( r ) " آليات تفعيل التمكين لتحقيق جودة الأداء في جامعة الأميرة نورا بنت عبد

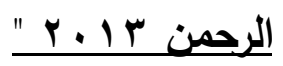

استخدمت الدراسـة في جانبها الميداني استبانة تكونت من عدة محاور شملت مجالات التمكين واسـتخدمت عدد مـن الأسـاليب الإحصـائية المناسـبة مثـل برنـامج SPSS وإسـتفادت مسن التحاليـل الإحصائية المناسبة مثل المتوسط الحسابي و الانحراف المعياري والنسب المئويـة واختبار T ومعامل ارتباط بيرسون • وقد أسفرت الدراسة عن نتائج متعددة كان من أبرزها :

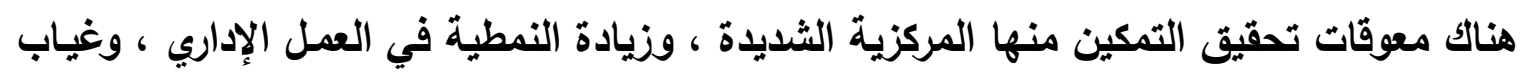

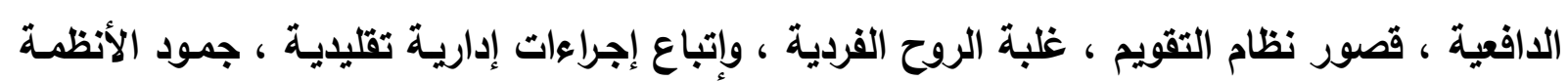
واللاوائح ، عدم المشـاركة في صنع القرار ، تدني مستوي كفاءة المـوظفين ، محدوديـة الرغبة في 
التمكن الإداري:مدخل لرفع كفاءة الأداء في مدارس التعليم العام في مصر (دراسة ميدانة) أ.م.د/ عبد السلام الشبراوي عباس

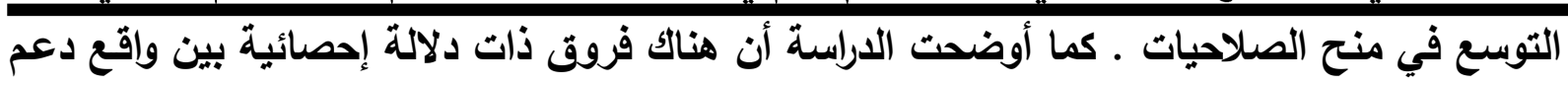
التمكين تعزي للمتغيرات التالية :

القيادة العلمية وسنوات الخبرة ، عدد الدورات التدريبية في المجال الإداري من وجهة نظر أفراد العينة وأكلت الدراسة على أهمية التدريب وورش العمل والتدوات والمحاضرات وضرورة إعادة النظر في الإجراءات الإدارية والهيكل التظظيسي ، وتوصيف المهام والتركيز على التواصل بين الأعضساء وتوفير البيئة والمناخ المناسب للتمكين ، وإقرار حوافز تثجيعية ، دعم الرضا الوظيفي ، نشر ثثافة التمكين [ب] دراسة بعنوان ( r ) " إدرالك التمكين وعلاقته بالرضا الوظيفي من وحهة نظر الإداريـات العاملات في جامعة الملك سعود 11 . ب " : استخدمت الدراسة المنهج الوصفي التحليلي ، واستخدمت أيضا الاستبانة كأداة وطبقت على عينة الدراسة وتوصلت إلي مجموعة من النتائج كان من أبرزها : ارتفاع مستوي التمكين لدي عينة الدراسـة كما شكلت المسئولية اعلي مستوي من الاستقلالية ثم المشاركة ـ وكان مستوي الرضا متوسطا بشكل

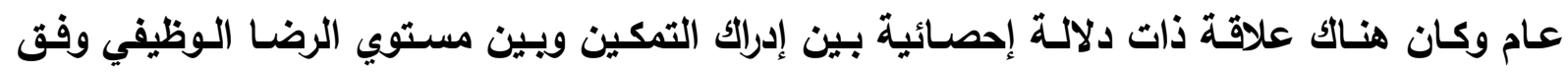
متغيرات الراتب وسنوات الخبرة وكذلك المؤهل العلمي ، والحالـة الاجتماعية ـ ـوأوصت الدراسـة ضرورة تحسين الشعور بمعني المشاركة وإعادة النظر في توظيف الوظائف وتحديد المهام والهيكل التظيمي ، وينـاء معـايير تقـويم الأداء ، والمسـائلة ونظـام للحـوافز وفـق مبـدأ الجــارة والكفــاءة ووضـوح آليـة المشاركة وتوفير المعلومات ، وإيجاد مناخ تنظيمي صحي يمتاز بالشفافية والتواصل وحل المشكلات

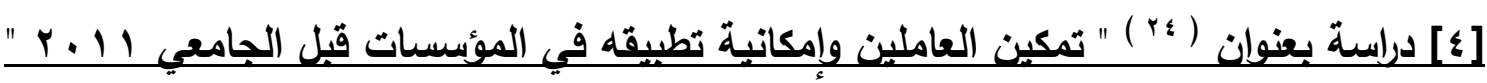
اعتمدت الدراسة على المنهج الوصفي واستخدمت الاستبانة كأداة حيث قدمت الاستبانة خاصسة بالعاملين واستبانة خاصة بالمديرين ومما تميزت به هذه الدراسة أنها قدمت معالجة نظرية شبه شاملة فيمـا يتعلق بـالتمكين كموضوع كاد أن يتبلور إلـي نظريـة ـ واتسمت هذه المعالجـة بـالعمق والاتسـاع والرجوع إلي مراجع متخصصة ذات قيمة وقد توصلت إلي مجموعة من النتائج كان من أهمها : وجود

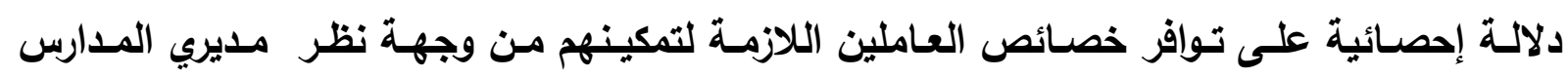
المعتمدة ـ وجود دلالة إحصائية على توافر خصائص بيئة العمل التي تسـاعد على تمكين العاملين مستقبلا من وجهة نظر مديري المدارس المعتمدة ـ وجود دلالة إحصائية على توافر محددات أداء العاملين لعملهم من وجهة نظر العاملين في المدارس المعتمدة ـ وجود اختلاف في أراء العاملين حول توافر خصائص بيئة العمل التي تساعد على تطبيق عملية تمكين العاملين . وقد أوضحت الدراسة ضرورة التركيز على تطبيق برنامه تطبيق الموارد البشرية والتنميـة المهنية والاهتمام ببرنامج التأهيل المؤسسي للامركزيـة والعمل على تطبيق برنـامج التطوير التكنولوجي ونظم المعلومات ـ واقتراحات الدراسة إجراء دراسات عن العلاقة بين ضغوط العمل وتمكين العاملين .وعمل 
التمكن الإداري:مدخل لرفع كفاءة الأداء في مدارس التعليم العام في مصـ (دراسة ميدانة) أ.م.د/ عبد السلام الشباوي عباس

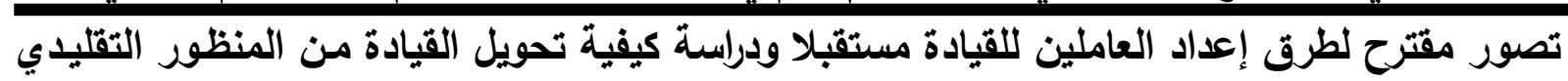
إلي القيادة التحويلية [0] دراسة بعنوان ( ب ) " اثر تمكين العاملين في الولاء التنظيمي لاي العاملين في شركة سونا طرلق

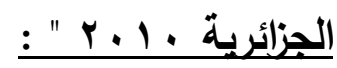
استخدمت الدراسة المنهج الوصفي التحليلي ، واستتدت إلي الاستبانة كأداة ـ وناقشت أربعة أبعاد للتمكين هي : معني العمل والكفـاءة والاستقلالية وتطوير العمل وتوصلت الدراسـة إلي عدد مـن النتائج كان من أهمها : هناك اثر لتمكين العاملين في الولاء التظيمي ـ عدم وجود فروق ذات دلالة إحصائية لمستوي إدراك التمكين لاي العاملين تعزي لمتغيرات الجنس والعمر والمؤهل العملي والمستوي الوظيفي ـ توجد فروق ذات دلالة إحصائية لمتغير الخبرة . وقد أوصت الدراسـة بأهمية تنمية ادارك العاملين وأبعاد التمكين الأربعة ولاسيما في المستويات الإداريـة الدنيا عن طريق تحفيزهم على تحمل المسئولية والارتقاء بمستوي ولائهم التنظيمي • [ 7 ] دراسة بعنوان ( بrr ) " التمكين الإداري لاي مديري المدارس التعليم العام في دولـة الكويت وإبرز معوقاته في ضوع الفكر الإداري الحديث ( . . r ) " : استخدمت الدراسة المنهج الوصفي واعتمدت على الاستبانة كأداة في الثق الميداني وقد توصلت الدراسة من خلال التحليل الإحصائي لاستجابات العينة إلي مجموعة من النتائج كان من أبرزها : ( درجة ممارسة مديري المدارس من عينة الدراسة من التمكين الإداري تعتبر ممارسة عالية ) . جاء بعد التحفيز الذاتي في المرتبـة الأولـي ويليه بعد العمل الجمـاعي في المرتبـة الثانيـة ثم السلوك الإبداعي في المرحلة الثالثة ثم تفويض السلطة في المرتبة الرابعة ثم التنمية المهنبـة في المرتبة الخامسة ، ثم جاء بعد اتخاذ المشاركة في اتخاذ القرارات في المرتبة السادسة ) توجد فروق ذات دلالة إحصائية في بعد تفويض السلطة لصالح أفراد العينة من الأكور . لا توجد فروق ذات دلالة إحصائية تعزي لمتغير النوع في بقية الأبعاد الأخرى ـ لا توجد فروق ذات دلالـة إحصـائية تعزي للمتغيـرات ( المؤهل العلمـي - عدد سنوات الخبرة ، المنطقة التعليميـة ، المرحلة التعليمية ) في جميع أبعاد التمكين الإداري • توجد مجموعة من المعوقات تحد من عملية التمكين الإداري مثل : ( عدم عدل نظام الحوافز ، عدم فاعلية نظام الاتصـالات ، ضعف الاقتنـاع بالتمكين للدي أفراد المنطقة التعليمية ، عدم الاهتمـام لوزارة بالبرامج التدريبية الجديدة ، صعوية الحصول على المعلومات ، عدم وجود تعاون مـع الرؤسـاء المباشرين ) وحصلت الدراسة إلي مجموعة من المقترحات من أهمها : ( ضرورة الاهتمـام بالاراسـات حول التمكين الإداري وعلاقته بـالجودة الثـاملة وتكنولوجيا المعلومـات والتميز الإداري ، الاغتـراب الـوظيفي ، ومسـتوي الصسراع التظظيمسي ) وضسرورة تسـليط الضـوء على التمكين النفسي وعلاقته بضغوط العمل والأكاء العاطفي والرضا الوظيفي 


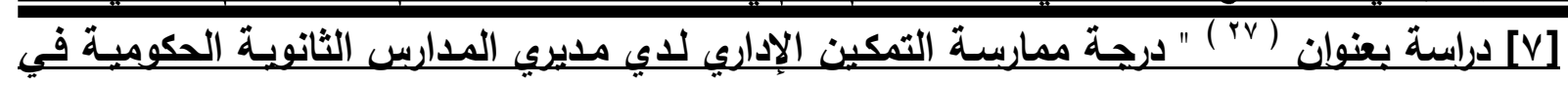

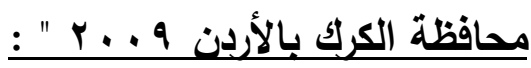

استخدم الدراسـة المنهج الوصفي واستخدمت أداة الاستبانة التي تكونت من 1 التقرة تغطي خمسة أبعاد للتمكين الإداري وهي : ( تفويض السلطة ، التحفيز الذاتي ، العمل الجمـاعي ، تطوير الثخصية ، تنمية السلوك الإبداعي ) · وكان من ابرز نتائج الاراسـة أن جميع أبعاد التمكين الإداري

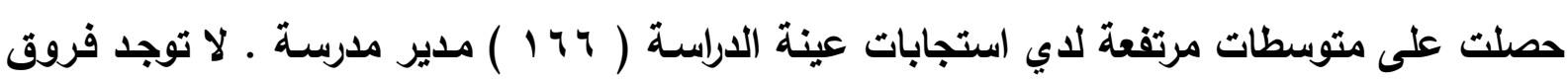

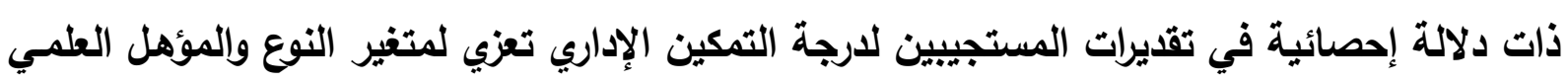
والتفاعل بينهم . توجد فروق ذات دلالـة إحصائية في تقديرات المستجيبين لارجـة التمكين الإداري تعزي لمتغير الخبرة ـ وقد قدمت الدراسـة توصيات من أهمها : ضرورة عقد برامج تدريبية للمديرين حول التمكين الإداري ، وإعطائه المزيد من التفويض للمديرين

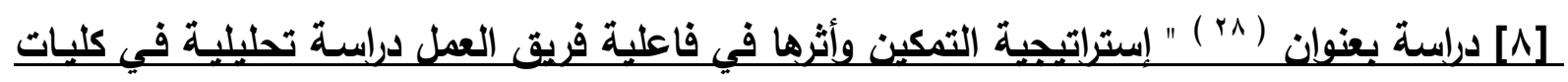

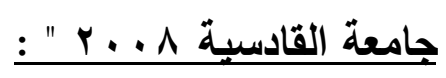

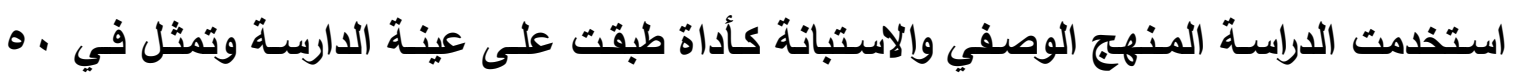
رئيس قسم وقد توصلت الدراسة إلي مجموعة من النتائج كان من أهمها : ( هناك اثر ذو دلالة إحصائية لإستراتجية التمكين في فاعلية فرق العمل ) . كما أن هناك توجها من قبل الإدارة نحو دعم ثقافة الفريق في العمل الجماعي ـ قدمت الدراسة مجموعة من التوصيات من بينهـا ضـرورة إيمـان الإدارة العليـا بإمكانـات أعضـاء الفريـق و الاقتـــاع بعدم مناسبة الفكـر الإداري التقليدي وضرورة إعطاء الحريـة الكاملـة لأعضـاء الفريق في التصرف في المسـائل الروتينية بحيث تكون هذه الحريـة مرتبطـة بوضـوح الروئية والرسـالة والأهداف الخاصـة بالمنظمـة وذلكـ في أذهـان الأعضاء داخل المنظمة [9] دراسـة بعنوان (9r) " الشعور بالتمكين الوظيفي لادي المدبرين من مستوي الإدارة الوسطي في دولية

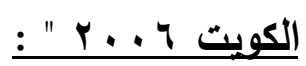

استخدمت الاراسة المنهج الوصفي واستندت إلي الاستبانة للتعرف على مستوي الشعور بالتمكين لاي العينة المذكورة ونظرة العاملين للمتغيرات الايموغرافية وهي ( جهة العمل - العمر - الجنس المستوي التعليمسي - الحالـة الاجتماعيـة - عدد سـنوات الخدمـة ) وذلك مـن خـلال فحص فرضيات الاراسـة و غطت عينـة الاراسـة حوالي هـ ؛ مـدير من مستوي الإدارة الوسطي في مختلف الأجهزة الوسطي في الكويت وقد أظهرث الاراسة مجموعة من النتائج منها : أن هناك توافر للمعلومات المعززة في الثعور بالتمكين الوظيفي • وهناك اختلاف بين أفراد ال عينة تعزي بلرجة أساسية لمتفيرات جهة العمل والمستوي التعليمي ومدة الخدمة والعمر ـ لم يكن هناك دور لعامل الجنس أو الحالة الاجتماعية للموظف على النظرة لأهمية العوامل المؤثرة بالشعور بالتمكين 


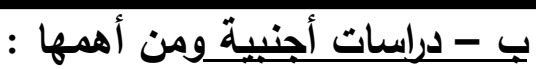

[1] دراسة بعنوان ( ·r ) الصراع بين الموظقين و المشرفين واثر ذلك في العلاقة بين التمكين الإداري

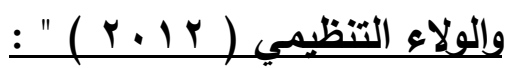

استخدمت الدراسة المنهج الوصفي واستتند إلـي الاستبانة كأداة والتتي طبقت على عينة تمثلت في او معلما من المرحلة الثانوية في هولندا ـ وق أبرزت الدراسة أن الصراع مـع المشرفين الإداريين يضعف التمكين الإداري بما يؤئز على مستوي الالتزام والولاء التنظيمي .

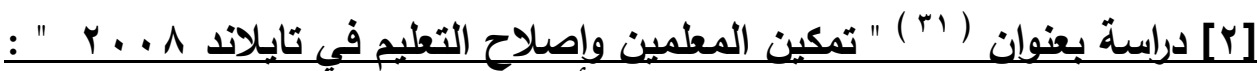
وقد استخدمت الدراسـة المنهج الوصفي التحليلي والاستبانة كأداة وكذلك ورش العمل التعليميـة والزيارات الميدانية والإثراف التأملي • وقد بينت الدراسة اثر دعم التمكين في زيادة وتحسين الإنتاجية لادي المعلمين وتوصلت الدراسة إلي أن التحسن الملحوظ في أداء عينة الدراسة وفقا للمقاييس الوطنية وتحسن إنتاجيتهم يرجع إلي دعم التمكين وتظوير القدرات الإدارية عن طريق التمكين الوظيفي • ومن ابرز ما تميزت به الاراسة أنها جمعت بين التعاون بين المدارس الابتدائية والجامعة

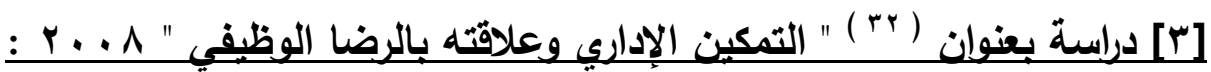
استخدمت الدراسة المنهج الوصفي واستتدت إلي الاستبانة كأداة ـ واستهدفت بيان الفروق العرقية و النوع على الرضـا الـوظيفي الناشئ عن التمكين وأبـزت الدراسـة أن أبعاد التمكين ترتبط بالرضـا الوظيفي وكذلك ترتبط هذه الأبعاد بالالتزام التنظيمي [ [ ] دراسـة بعنوان ( بr ) " التمكين والرضـا الوظيفي والالتزام التنظيمي في الجامعات الثثلاث الخاصـة

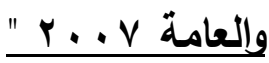

استهرفت الدراسـة معرفة العلاقة بين تمكين أعضـاء الهيئة التدريسية والرضـا الوظيفي والالتزام التظظيمي في ظل المساعلة المجتمعية عن المخرجات التعليمية ـ واستخدمت الدراسـة المنهج الوصفي التحليلي • وكان من ابرز نتائجها أن تمكين أعضاء الهيئة التعليمية له اثر ايجابي على تحقيق الرضا الوظيفي الذي ينعكس بدوره ايجابيا على الالتزام التظظيمي وهذا له أثره على التجويد فيؤدي بدوره إلي تحسين المخرجات التعليمية [0] الاراسة بعنوان ( ؛" ) اثر تمكين المعلمين على التزامهم ورضاهم التظظيمي والوظيفي على المواطنة

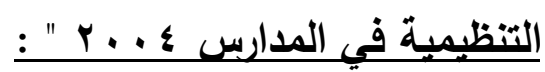
استخدمت الدراسـة المنهج الوصفي ، واستعانت بمقياس Short and Rinehart لقياس

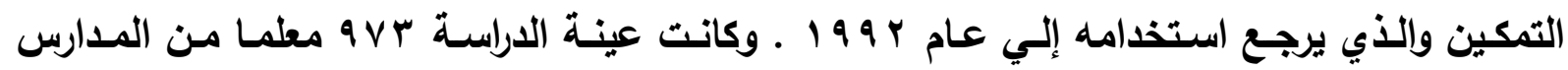
الثانوية والوسطي في إسرائيل • وكان من نتائج هذه الدراسة أن هناك علاقة ذات دلالة إحصائية بين مدركات المعلمين على مستوي التعليم الأي يحصلون عليه ومدي أدائهم لسلوك المواطنة التنظيمي و و الالتزام نحو المنظمة ـ كما أبرزت دراسة أن أبعاد التمكين المتمثية في صنع القرارات وفاعلية الذات ، 


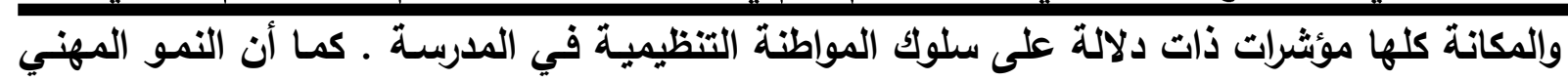
والمكانة وفاعلية الأات تمثل دلالات على الأداء التنظيمي لادي المعلمين

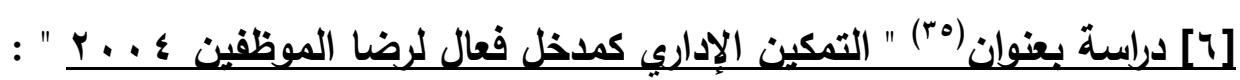

استهدفت الدراسة التعرف على الأسباب التي تجعل تمكين العاملين أكثر من مجرد شعار سائد كما هدفت الدراسة إلي تحقيق رضـا الموظفين من خلال عملية التمكين ـ وقد طبقت الدراسـة في منظمـة اكسفام الدولة البريطانية ، وقد استخدمت المنهج الوصفي واستتدت إلي الاستبانة كأداة ـ وكان من أهـ نتائجها : إذا سـمح للموظقين أن يكون لهم رأي في القضسايا التي يتعين عليهم التعامـل معها يشعرون بان لهم ملكية في هذه العملية ـ وأوصت الدراسـة بضرورة السماح للمدرسين للوقوف على

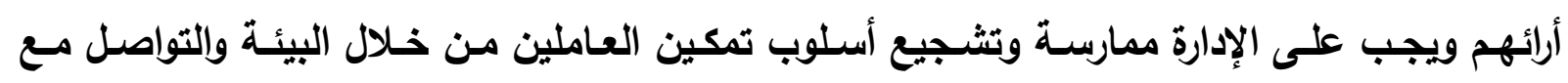
الموظفين [^] دراسـة بعنوان ( بr ) " القيادة الابيمقرطية وتمكين العمداء والعاملين في كليات المجتمع في الولايات

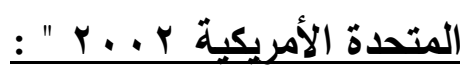
استهدفت الدراسة البحث في دور العمداء كلية المجتمع وعلاقتهم مع العاملين في عدد من كليات المجتمع في الولايات المتحدة الأمريكية وأبرزت الدراسـة مجموعة من السمات التي يتسم بها المنـاخ التظيمي لهذه الكليات وهي سيادة النمط القيادي الأوتوقراطي وطريقة اتخاذ القرارات من اعلي إلي

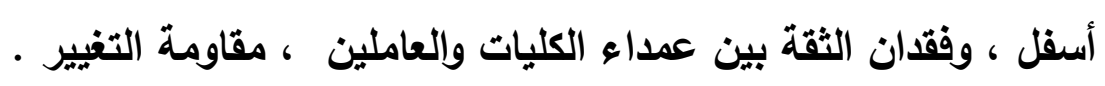
وذكرت الدراسة أن السمات السلبية السابقة تثكل عوائق التمكين للعاملين و العمداء و اقترحت الدراسـة مجموعـة مـن المقترحسات ومجموعـة مسن الوسـائل للمسـاعدة على تطبيق تلك الاستراتيجيات لتطوير و تفويض السـلطة ـ وهذه الوسـائل هـي : ( تعزيز المشـاركة الديمقراطيـة للعاملين و تطوير المعرفة لدي العاملين في الكليات والتركيز على تشجيع الاستقلالية لايهم والثقة التظيمية وإيجاد مناخ تنظيمي يحقق هذه (الثقة ) [^] دراسة بعنوان ( rr ) " العلاقة بين المناخ التنظيمي والتمكين الإداري من وجهة نظر الممرضات في

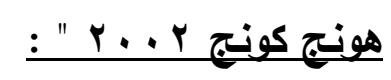
استخدم الباحثان المنهج الوصفي وأداة الاستبانة التي تم توزيعها على اسب ممرضـة في هونج كونج لفحص العلاقـة بين المنـاخ التظيمـي بأبعـاده المختلفة ( النمط القيادي - تجـانس العمل التحدي - العمل كفريق - المشـاركة في اتخـاذ القرارات ) ويـين التمكين الإداري ـ وتوصلت الاراسـة لوجود علاقة طردية ايجابية بين المناخ التظظيمي وأبعاده المختلفة ويين التمكين الإداري • وكانت اقوي العلاقات الارتباطية بين النمط القيادي ، العمل كفريق من جهة ، وبين التمكين الإداري من جهة أخري،

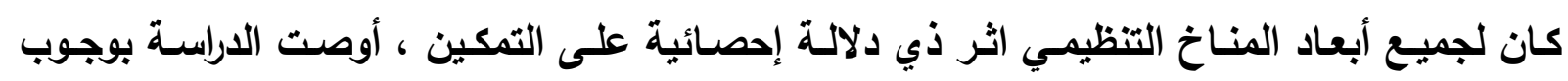
تشجيع الممرضات على المشاركة في عملية اتخاذ القرارات لما له من اثر ايجابي على عملية التمكين 


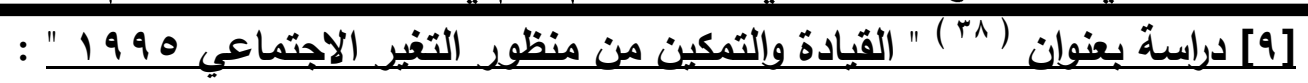

استخدمت الدراسـة المنهج الوصفي ، ثم استعانت بالاستبانة كـأداة لتحليل العلاقة بين القيـادة وتمكين العاملين ودورها في التغيير الاجتمـاعي الفعال في الولايـات المتحدة الأمريكية وكانت عينة

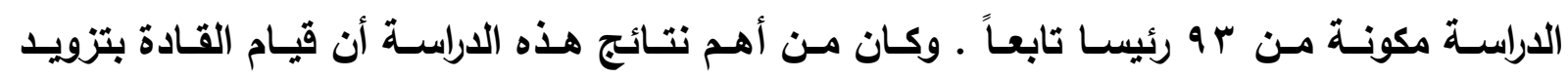
المرؤوسين بالتقديم ومنعهم الفـرص للتفـاوض والتمكين عند اتخـاذ القرارات يـؤدي إلـي دعم شـور

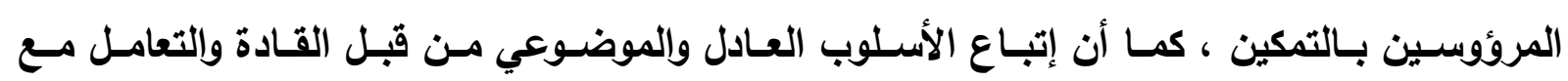
المرؤوسين يؤدي إلي ارتفاع الرضا عند المرؤوسين بما يؤدي التصرف حسب توقعات الرؤسـاء أو رؤسبائهم

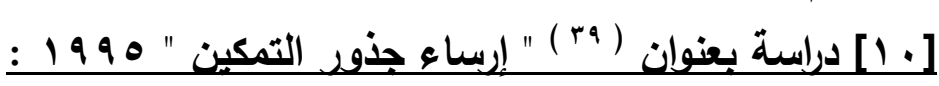
هذه الدراسة على الرغم من أنها نظرية إلا أنها افترضت أن الممارسات في التفكير الإداري تجاوز الأمور التصورية ونظرت الدراسة إلي التمكين على انه بناء إيديولوجي ـولإظهار ذلك قامت الدراسـة بمتابعة التغيرات في الفكر الإداري وحاولت تقييم تلك التغيرات من خلال تحليل القوي المتغيرة والفرص التي تحكم الإدارة ، كما أنها تسمح ببعض الأفكار مثل التمكين لتصبح قابلة للتحقيق والتنفيذ

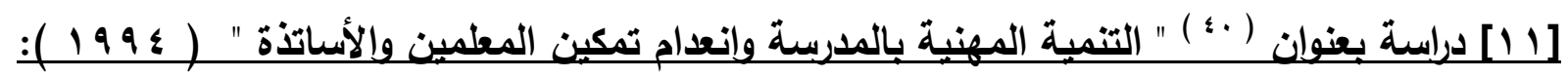
وقد تمث هذه الدراسة بولاية ميتشيجان الأمريكية ـ وخلصت الدراسة إلي أن محو أمية التفكير لا يمكن أن يتحقق ما لـ يتم تحريز المعلمين من فكرة إتباع الأوامر دون جدال ـ كما أن تطوير الفكر

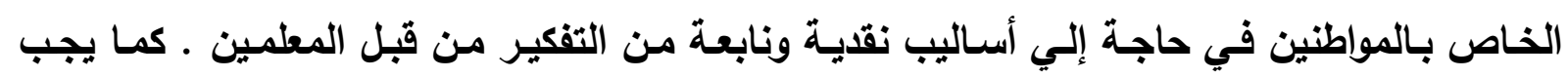
الاستثمار في عقول المعلمين بدل من الاستثمار في مجموع من التوجيهات يتبعها المعلمون والتمكين

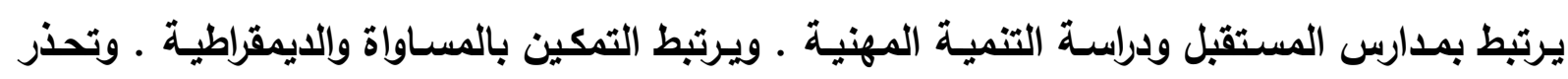
الاراسة من ذرع نظام الطبقات في نشاء مدارس تثمية مهنية

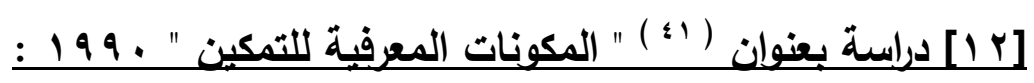

هي دراسـة هامـة في مجال التمكين حيث تصدت لتحديد المعايير التي يمكن من خلالها قياس تمكين العاملين في المنظمة ـ وقد توصل الباحثان إلي أن المشاركة وحدها غير كافية لمحاولـة تطبيق التمكين ـ كما أن نجاح المنظمـة يتأثر إذا كانت مهامها ذات معني ، كمـا يشعر الموظفون بقدرتهم على أداء العمل إذا كانت المنظمـة تأخذ بمقترحاتهم · ويري الباحثان يركز على الأحداث الخارجية مثل مواصفات الوظيفة ، سـوك القائد ـ واقترح الباحثان استبدال ذلك بـالتركيز على التجديد وعلى

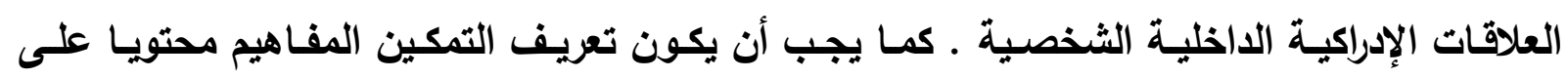
نموذج نفسي لتقييم المهام الأربع التي تؤدي إلي تحفيز داخلي حقيقي لأداء العمل وهي : التأثير على نتائج العمل - المقدرة أو الكفاءة الأتية - قيمة ومعني العمل - الاستقلالية . كما يجب أن توجه جهود التمكين في كل الاتجاهات السابقة . 


\section{تعليق على اللدراسات السابقة}

تجدر الإثارة إلي أن اختيار الدراسات السابقة والبالغ عددها تسع دراسات عربية واتثنتي عشرة

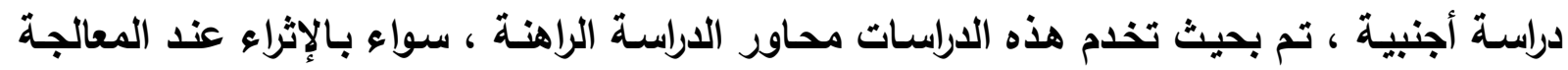

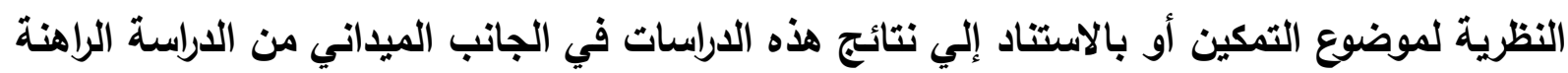

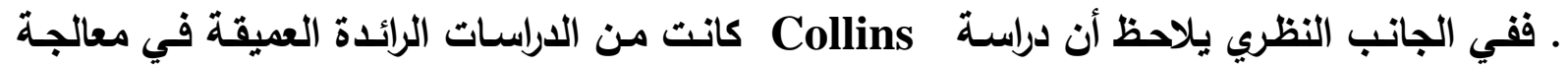

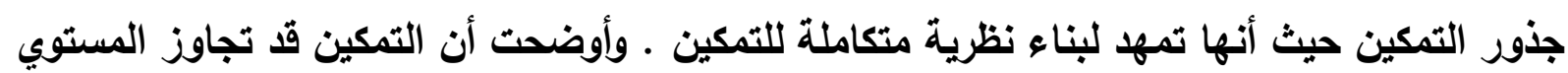

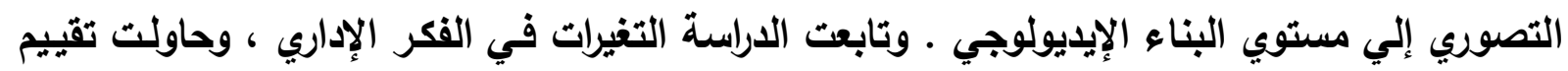
تلك التغيرات وهذا يمثل خطوات حقيقية نحو بناء نظرية للتمكين .

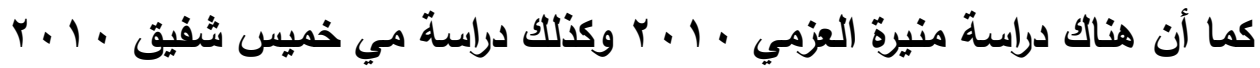

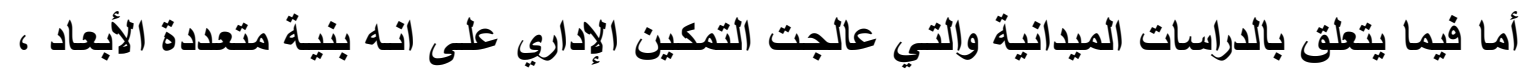

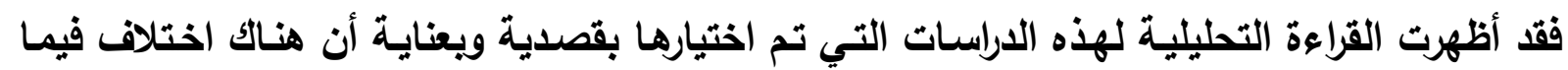
يتعلق بأبعاد التمكين باختلاف البيئة وإلمناخ والظروف التي تجري فيها الدراسة وكذلك اختلاف طبيعة التهات العمل والنشاط ومستوي الإدارة .

وأظهرت الدراسـات السـابقة أن التمكين الإداري يرتبط بالجواتب الايجابيـة في بيئات العمل مثل التل

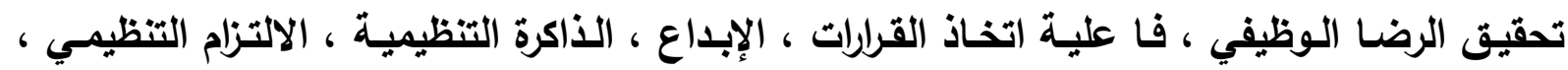
الالتزام المهني ، سلوك المواطنة التنظيمية .

ومن الملفت للنظر أن هناك تنوع في تحديد أبعاد التمكين الإداري في الداراسات السابقة ، فبينما

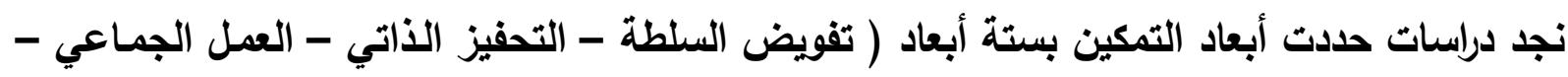

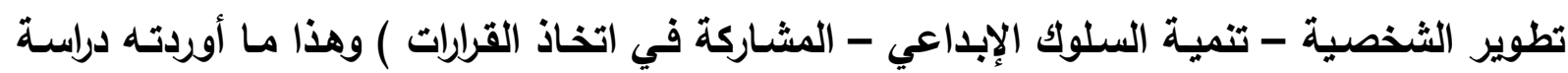
منيرة العزمي • 1 ب نجد أن هناك من حلد أبعاد التمكين بسبعة أبعاد ( تفويض السلطة - المشاركة

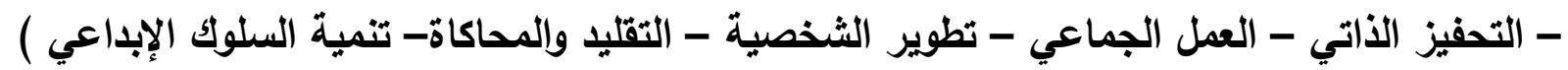
كما أن هناك من قصر هذه الأبعاد على خمس فقط هي ( تفويض السلطة - التحفيز الذاتي -

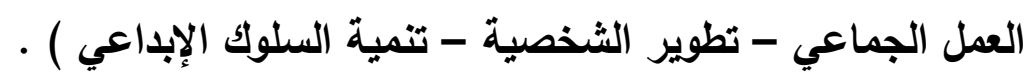

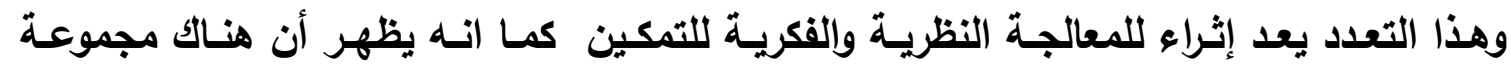

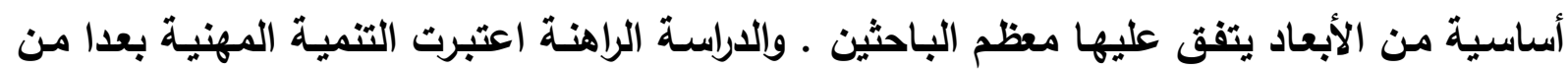

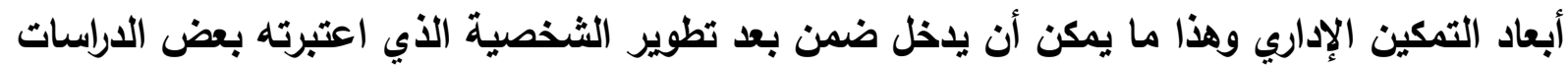

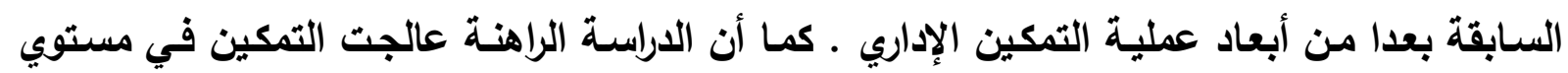

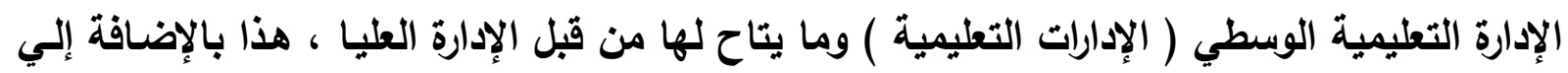

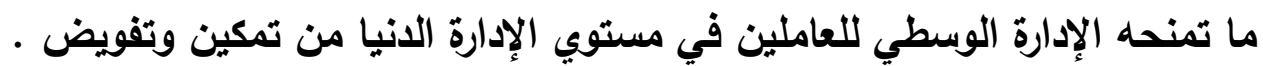

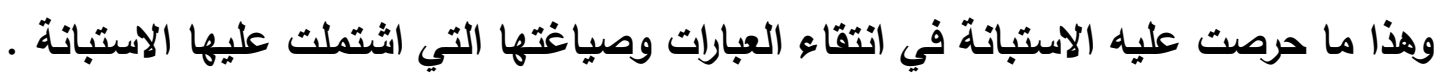




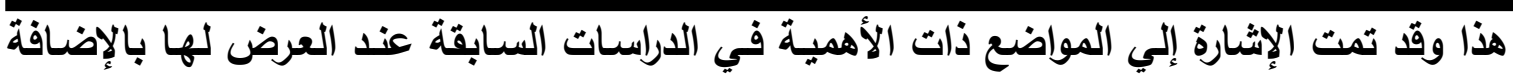

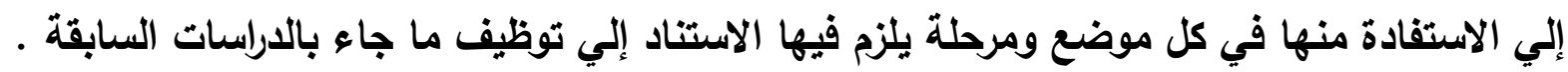

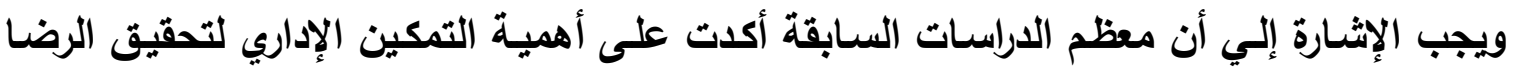

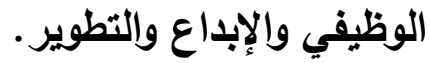

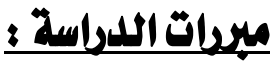

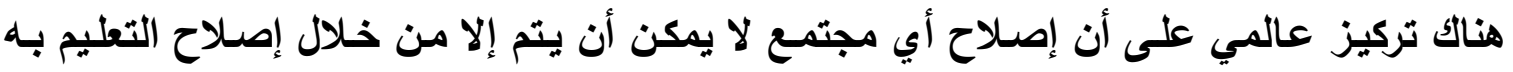

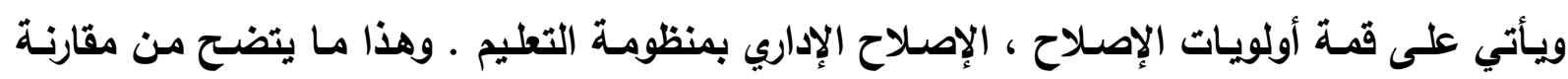
التعليم المصري بالتعليم في بعض الدول التي بدأت معنا رحلة التطوير والتهضة ولكنها سبقتنا بمراحل

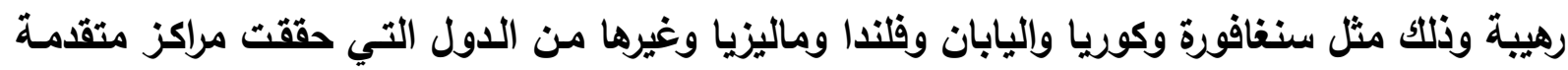

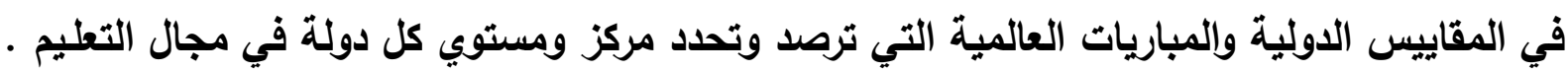

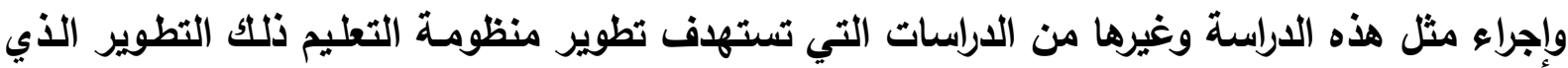

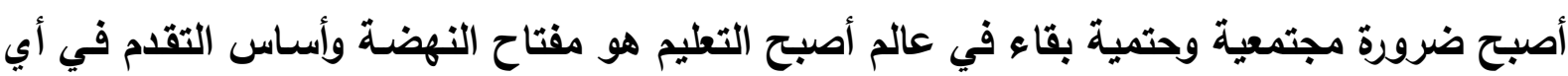

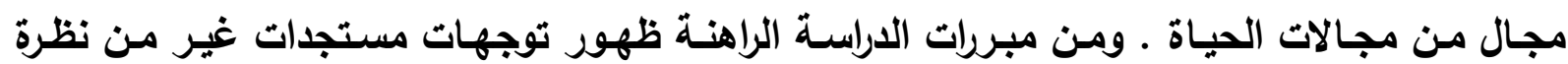
المؤسسات التعليمية وغيرها بطبيعة ونمط ونوع وشكل العلاقة بين المديرين في مختلف المستويات

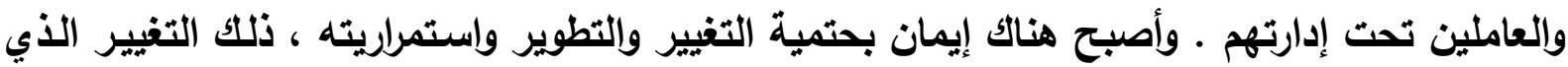

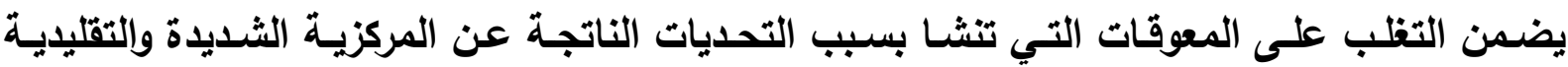

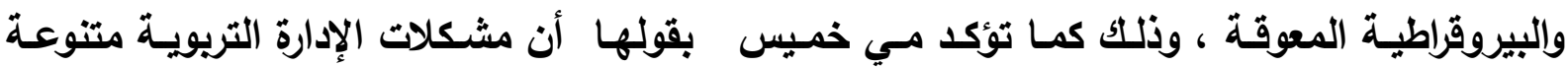

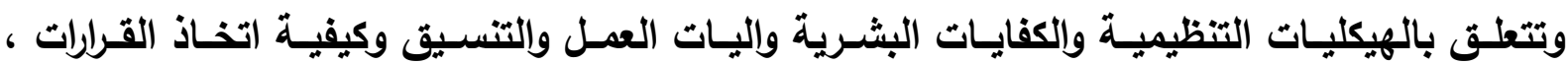

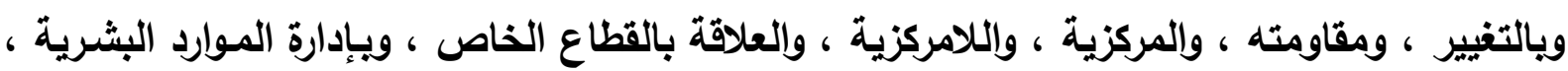
وموازنـة الضغوط والإمكانيات المتاحة ـ وأضـافت مي خميس أن التطوير الإدارات التريوية في الدول

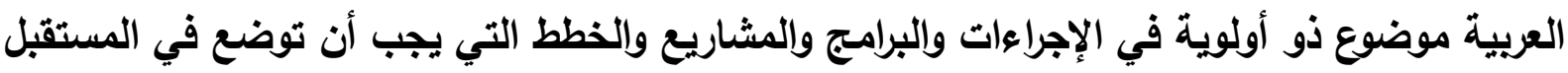

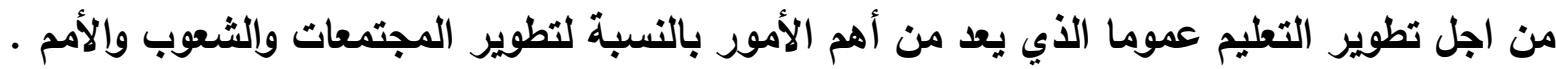

\section{المحور الثاذية}

\section{(المعالجة النظرية للدراسة (1)}

سبقت الإشـارة إلـي أن هناك تأكيد على أن التمكين الإداري يعد أداة للإصـلاح الإداري ، ومدخل

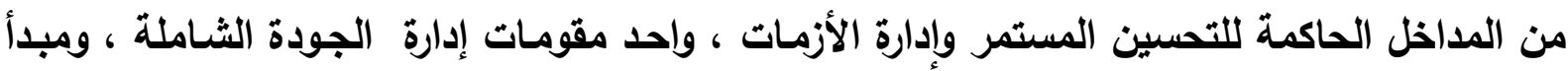

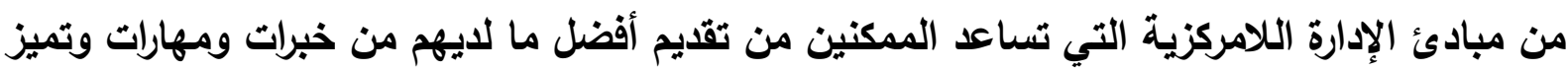

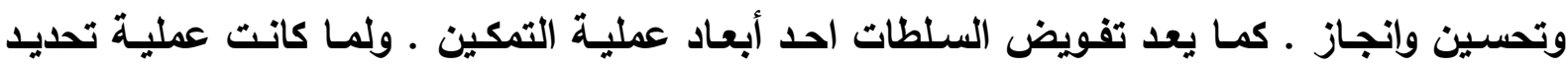
المصطلحات من أهم العمليات التي تحقق التواصل الفعال والفهم الصحيح فتجدر الإثـارة هنا تحديد مصطلح التمكين من التم 


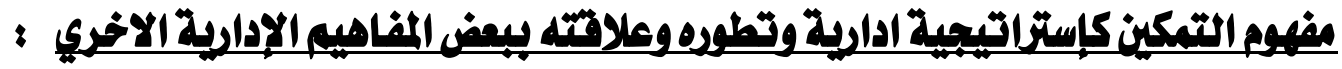

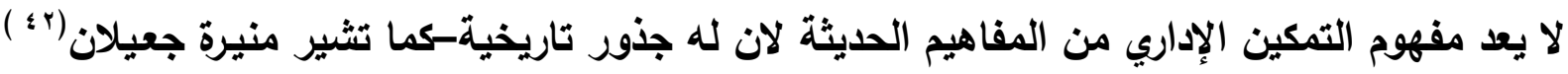

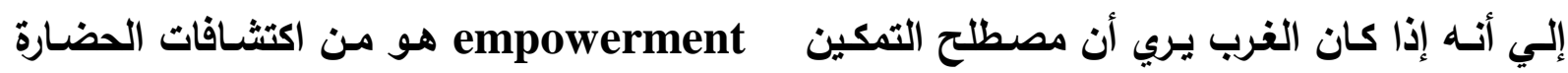

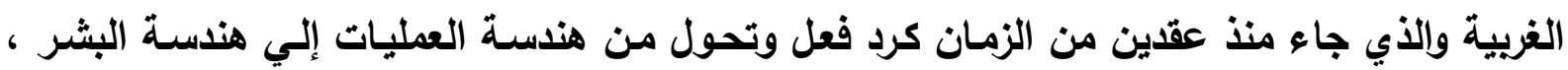

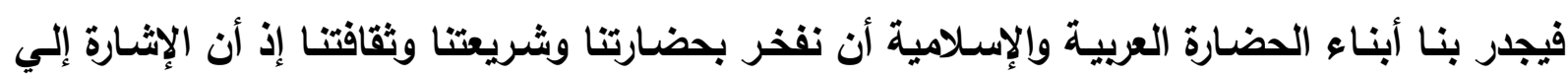

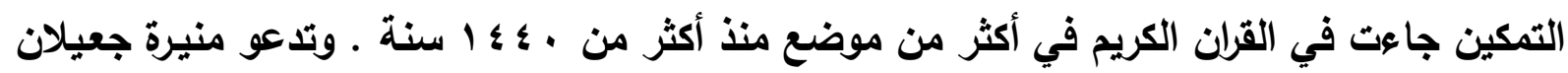

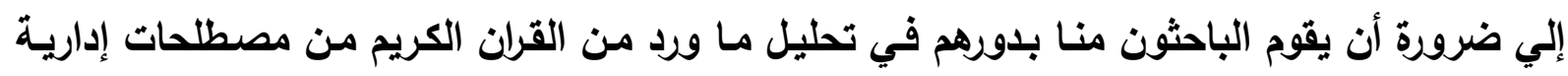

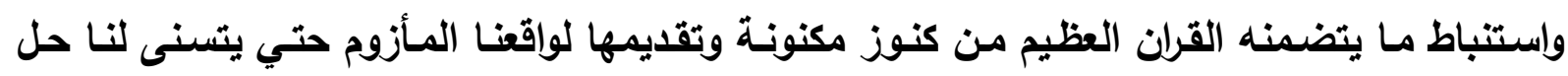

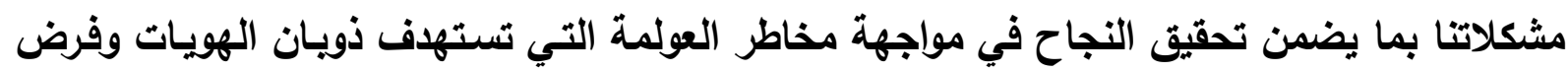

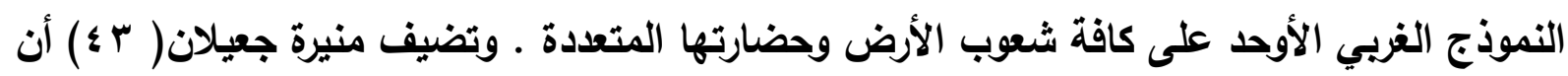
مفهوم التمكين كما ورد في القرآن الكريم يختلف من حيث طبيعة التمكين فهناك تمكين رياني للمرسلين والصالحين وهناك تمكين الإنسان للآخر في حياة البثر مثل تمكين عزيز مصر لسيدانا يوسف علئ عليه

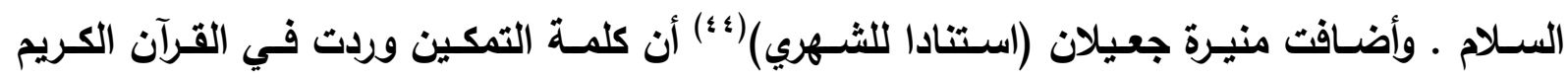

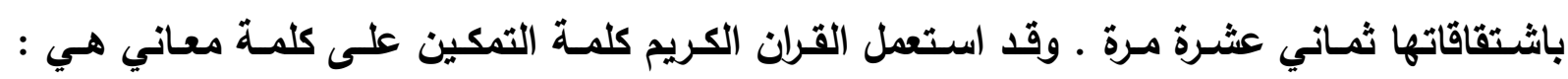

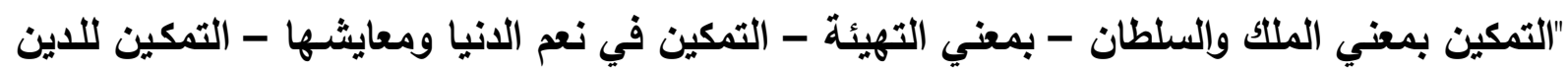

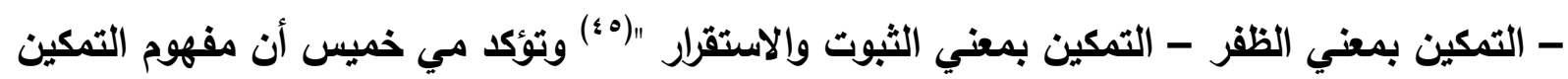
في ذاته ليس مفهوما جديدا ، ولكنه مر بعدد من المراحل حتي ظهر بالصورة التي هو عليها الآن ويدا

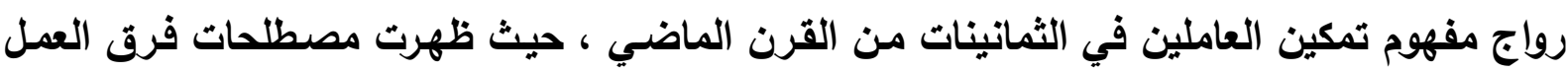

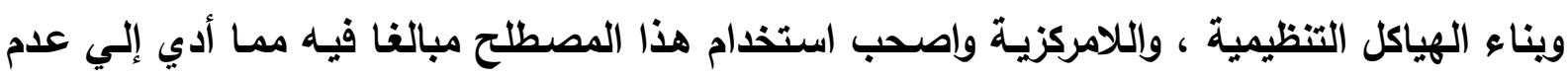

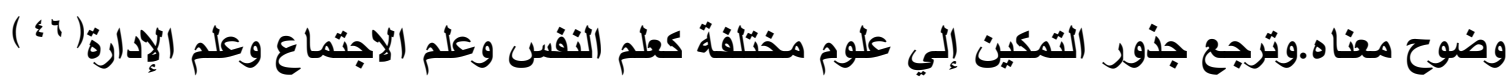

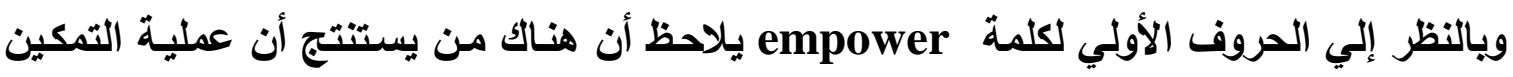

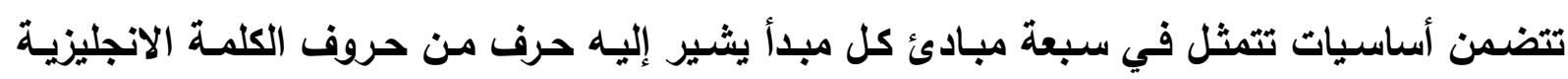

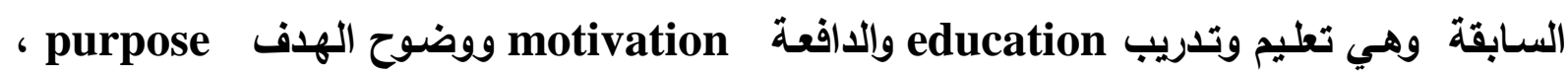

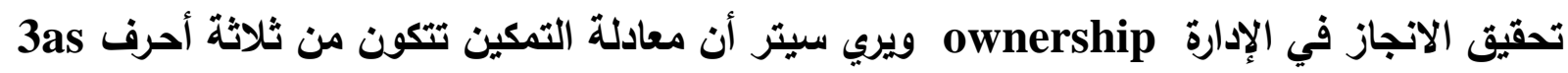

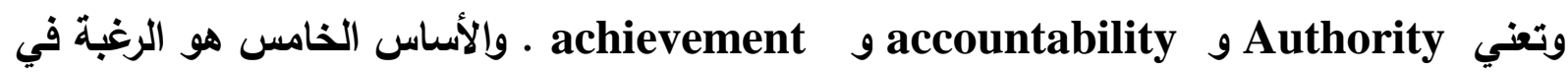
التغيير Respect وقد ذكر محمود أبو النور عبد الرسول أن مفهوم التمكين برز في نهايـة الثمانينات من القرن الماضي ولاقي رواجا في التسعينات من ذات القرن ، نتج عن زيادة التركيز عن العنصر البشري التردي داخل

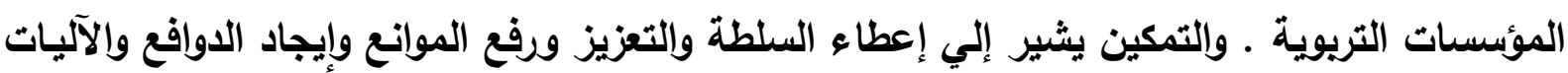




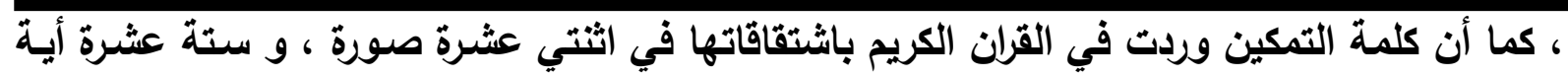

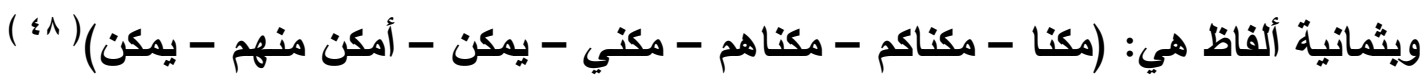
وأضاف أبو النور أن كلمة empower بمعني يمنح سلطة ، يخول ، يفوض . :التمكين وأسلوب جمباكابزن (البابان )

سبقت الإثارة إلي أن مفهوم التمكين - كأسلوب إداري - تقوم فلسفته على أهمية تقليل المركزية،

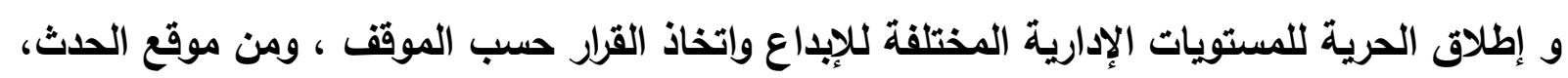
وهو يقوم على فكرة المثاركة والانفتاح الإداري ، ويعد وسيلة حديثة من وسـائل الإدارة ، وهو ممارسـة تثجع العاملين على تحمل المسئولية الثخصية ، وهو عملية نقل مراقب ومحسوب للسلطة من الإدارة

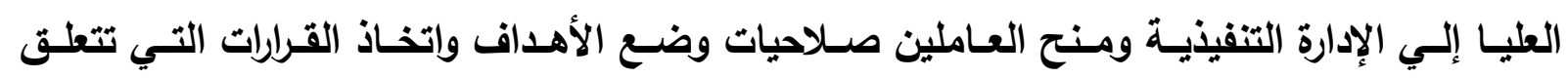

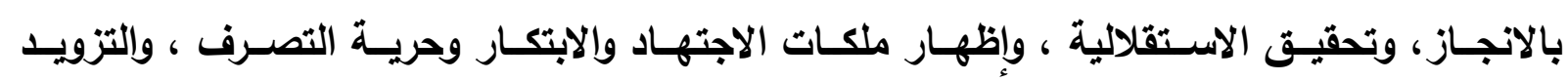
بالمعلومات ، والمساهمة الكاملة في اتخاذ القرارات ضمن بيئة ومنظومة إدارية متناغمة . . مما سبق تظهر العلاقة بين التمكين ويين أسلوب كايذن حيث جمبا كايذن أسلوب إداري ياباني طوره الباحث الياباني Amie ، ففي اليابانية كلمة جمبا تعني الموقع الفعلي للحدث ، وكلمـة كايذن تعني الأسلوب الأي ياخل تحسينات تدريجية صغيرة تقلل التكاليف و الهـر وتزيد الإنتاجية ، وتترجم الكلمـة إلـي الإدارة مـن موقع الأحداث ـ وهذا مـا يتمشـي مـع فلسفة اللامركزيـة ـ ويتضسمن التطوير المستمر في توظيف عناصر الإدارة كالتخطيط و التنفيذ والمتابعة والتطوير ، ويشـل كايذن جميع

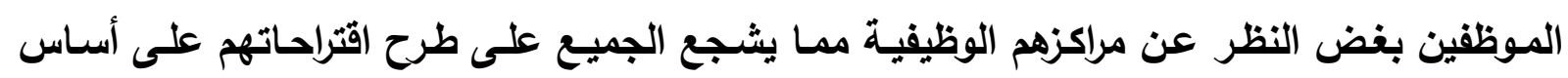

منتظم لتطوير الأداء وييئة العمل استنادا إلي فلسفة التحسين إلي الأفضل والتقليل من الهدر ( هـ ) وتجدر الإثارة إلي أن هناك معه كايذن في طوكيو أسسه Amai وله فروع في العديد من دول العالم ـ وكلمـة كايذن فهناك من يري أنها تعني التغيير الجيد باعتبار أن كلمـة Kai م تعني التغييز

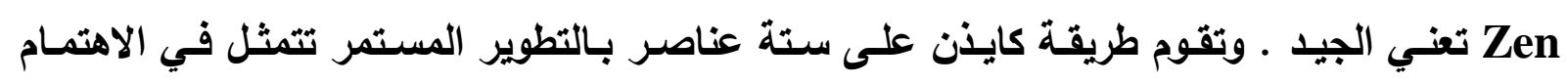
بالمستفيذ من الخدمة - التركيز على عمل الفريق - عدم إغفال المواعيد - الجودة عبارة عن حلقات ، التواصل مع العاملين - توظيف التكنولوجيا في بيئة العمل ـ وتتكامل العناصر السـابقة ، وذلك كما يشير القحطاني إذ أن استخدام كايذن قد يتم بالتزامن مـع المدخل الياباني المعروف بخطة الخطوات الخمس ( Five step plan ) كما أن هناك مبادئ أريعة لكايذن تتمثل في العمليات والنتائج والتنفيذ على كامل النظام وعدم توجيه اللوم ووضع العملاء على رأس الأولويات.

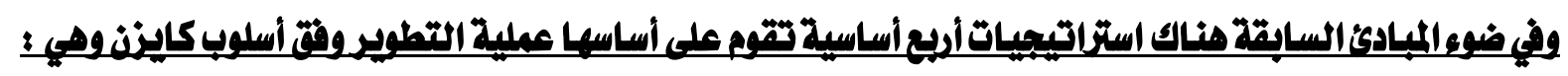

$$
\begin{aligned}
& \text { [ץ] ] ( خطط ، طبق ، راجع ، وطور ) } \\
& \text { [1] ] وضع قواعد التشغيل } \\
& \text { [ع] القضاء على الهدر } \\
& \text { ] ] - التثقيح }
\end{aligned}
$$



وهنالك وصايا ثمانية وضعها Amai لتطبيق كايذن تتمثل فئي

التفكير في كيف تتفذ الاقتراح الجديد - لا تقبـل مبررات انخفـاض الإنتاجية - لا تبحث عن الكمال- صحح الأخطاء فور وقوعها - كن يقظا لملاحظة فرصة التطوير المختلفة - اعمل دائما على مستويين مستوي الأفراد ومستوي العمليات ـ وهنـا يكمن جوهر تميز مفهوم كايذن انـه يعمل على

مستوي العمليات ومستوي الأفراد بعكس أسلوب الهندرة الذي يقتصر على مستوي العمليات فقط(ه )

\section{التمكينوالتقفيض والالامركزية والاجحلال}

سبقت الإثارة إلي أن التمكين الإداري في قطاع التعليم هو فلسفة إداريـة تقوم على منهج الإدارة المفتوحة ، ويعني منح القادة التريويين الاستقلالية والمقدرة بحيث تصبح لايهم ملكة الاجتهاد وإصدار الأوامر والاهتمام وحرية التصرف في المواقف ، وحل القضايا والمشكلات التي تحدث خلال ممارسـاتهم - أعمالهم

والتفويض delegation هو عملية يسند من خلالها للأشخاص المهام من جانب الإدارة العليا

التي تحاسبهم عليها. فالتفويض هو صلاحيات تمنح وقد تسلب مرة أخري (10. وهنـاك مـن يـري أن التفويض يتعلق بالسـلطة دون المسئولية ، فالمسئولية لا تفوض إطلاقـا ، ويعني ذلك أن تظل مسئولية الرئيس عن الاختصاصات قائمة أمام الموكل إليه حتي وان كان قد فوض إلي احد معاونيه سلطة اتخاذها ـ ويقوم التفويض على ثلاثة أركان هي ( rه ): السلطة : وتعني اتخاذ القرار ، ثم المسئولية : وتعني التزام المرؤوس بالتزام المهمة ثم المساءلة حيث لا يعني التفويض إعفاء صـاحب الصـلاحية من المسئولية النهائية والسلطة هي الحق في اتخـاذ الأوامر للآخرين وهـي تتبع مـن المركز الوظيفي للفرد ـ والنفوذ هو القدرة على التأثير في الآخرين ليتصرفوا بطرق معينة ( به ).

وهناك من يورد مجموعة من الفروق بين التمكين والتفويض تتضح من الجدول التالي ( ؛ه)

\begin{tabular}{|c|c|}
\hline التفويض & 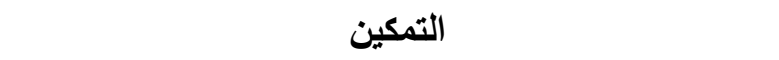 \\
\hline نقل جزء من الصلاحيات للمرؤوسين & - إتاحة الفرصة للمرؤوس ليفكر ويقرر \\
\hline إتاحة السلطة في مجالات محددة & - إتاحة الصلاحيات للعاملين في نطاق أوسع \\
\hline المسئولية تظل مسئولية من قام بفعل التفويض & - النجاح والفشل ينسب للمكين والفشل مسئوليته \\
\hline المطلومات متاحة على قدر جزئية التفويض & - لميادة لذاتيه \\
\hline أن أخطا الموظف قـ يسحب التفويض & - أن أخطأ الموظف يتحري السبب ويقوم بالعلاج \\
\hline قد يكون مؤقتا وقد يلفي أو يعدل & - يظل التمكين قناعة واختبارا استراتيجيا مستمرا \\
\hline
\end{tabular}

وتؤكد مس خميس شفيق على نفس الفروق بين التمكين والتفويض وكذلك محمود أبو النور وفاطمة عبد الحميد وآخرين . 


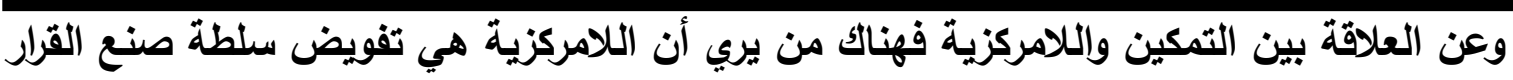

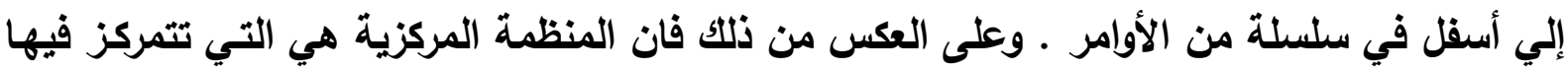

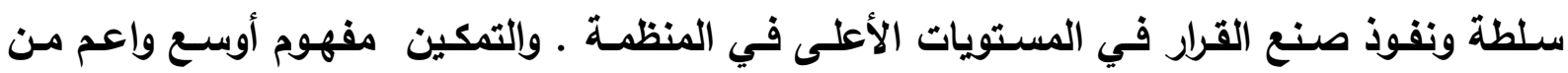

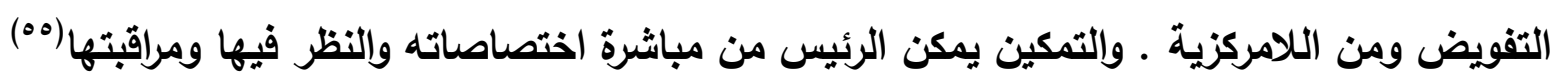

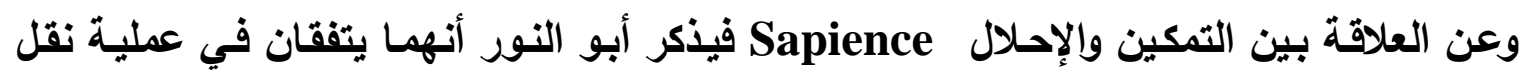

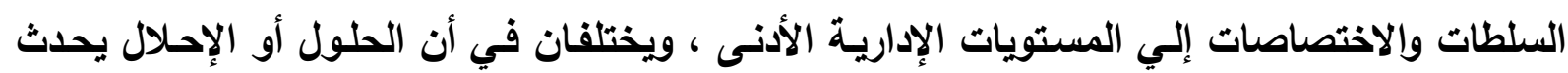

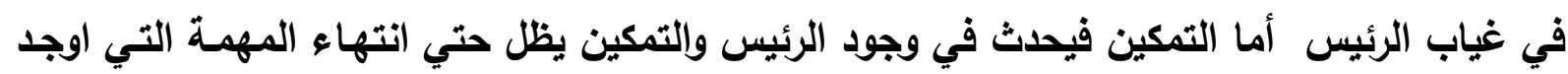

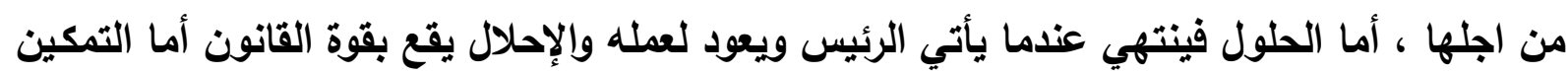

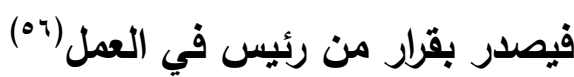

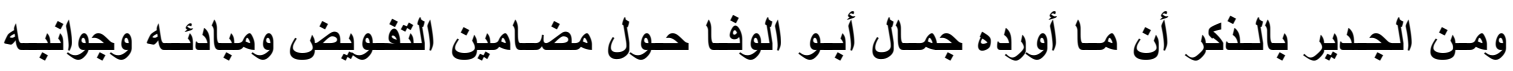

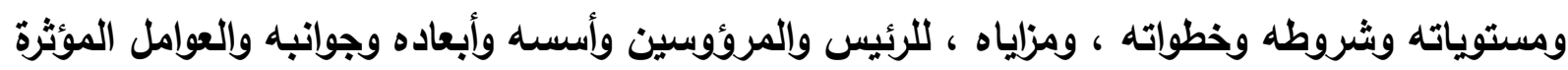

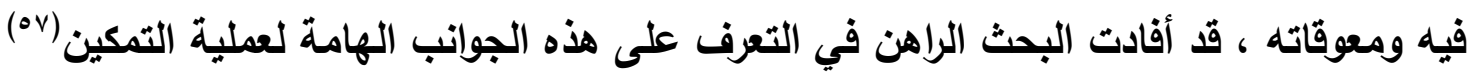

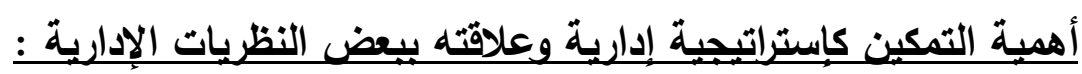

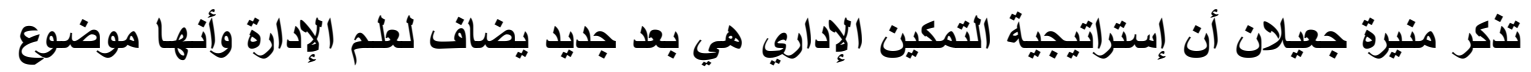

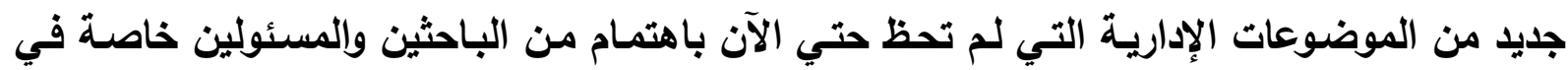

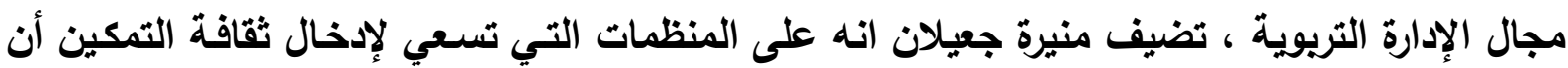

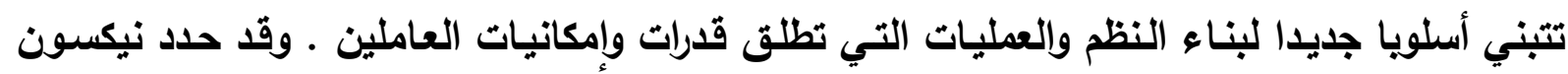

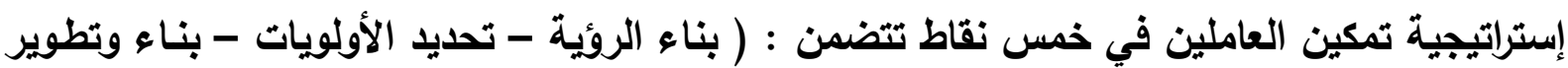

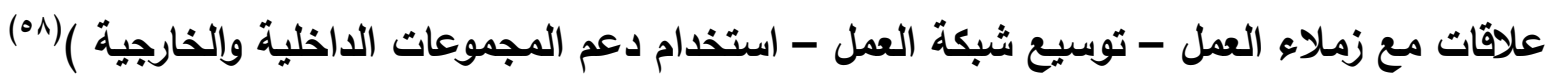

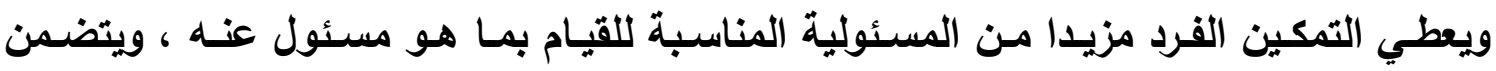

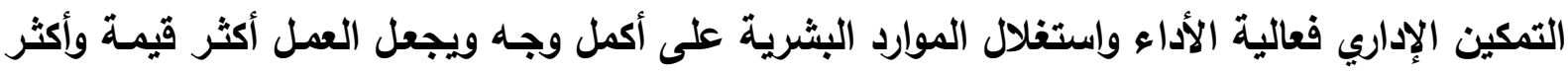

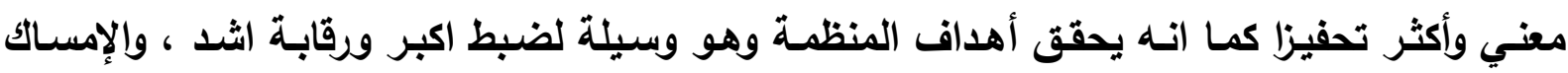
بالفرص المواتية لنمو الثخصية والتطوير الذاتي وكذلك يؤدي إلي تفرغ القيادات الإداريـة العليا للمهام

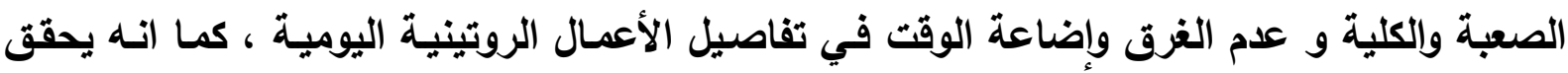
الانتماء في أفضل صوره ، ويوفر فرصة السرعة في اتخاذ القرار وتحقيق الانجاز بدون بيروقراطية

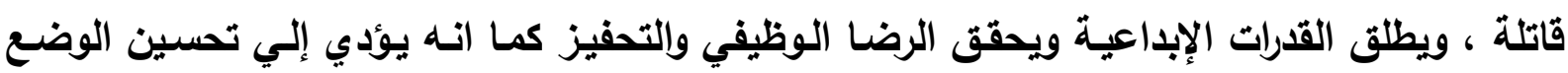

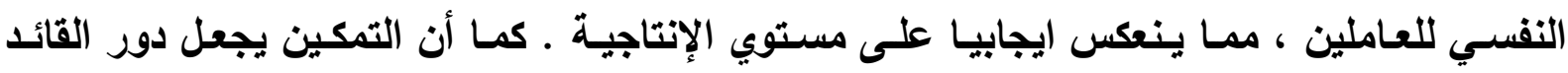

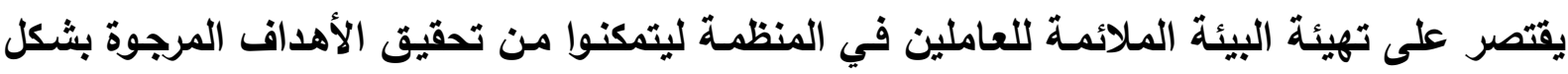

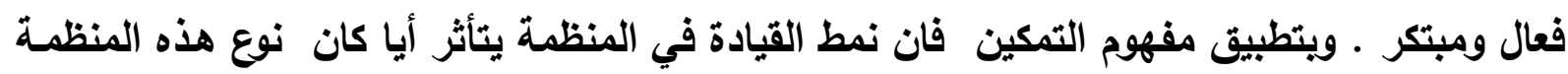



، كما يؤثر على مجموعة العناصر الفعالة بها مثل الهيكل التنظيمي ونظم الحوافز ، والأجور ، وتصميم

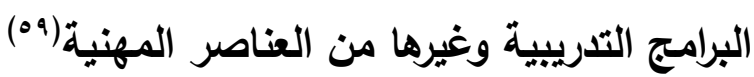
وعن علاقة التمكين ببعض النظريـات الإداريـة فقد اتضـح مما سبق أن التمكين أن لـه منطلقات الفكريـة والنظريـة والفلسفية ، ولذلك يرتبط بالعديد من النظريـات الإداريـة خاصـة عند ارتباطه بالعمل داخل المؤسسة ـ ويصبح التمكين نظاما إداريا يستخدم للنهوض بالعمل داخل للمؤسسة أيا كان نوعها ، حيث يـظم العمل بـين الروئسـاء والمرؤوسين ويسين المـيرين والعـاملين ويسين المستويات الإداريـة المختلفة ـ وتذكر مس خميس أن نظريـة التمكين لم تكتمل جواتبها حتـي الآن ولذلك يطلق عليه انهـ عملية إدارية، وهي عملية كل ما يدور فيها عبارة عن محاولات لرصد ملامح نظرية إدارية متكاملة(·") وتوضح مي خمس أن هناك علاقة بين عملية تمكين العاملين والنظريات التي تتتمي إلي المدرسة السلوكية مثل نظريـة X التي تؤكد على التحكم الخارجي للسلوك الإنساني ، ونظريـة Y التي تؤكد على التحكم والضبط الذاتي وفيما يتعلق بنظريـة ماسلو ذات الحاجات الخمس ( حاجات فسيولوجية - الحاجة إلي الأمن الحاجة للحب - الحاجة للتقدير والاحترام - حاجة تحقيق الذات ) وترتبط حاجـة تحقيق الذات بعملية التمكين وعن النظريات التي تتتمي إلي نموذج البعدين في القيادة فتذكر مـ خميس أن هناك نموذجا لتغيير السلوك القيادي المتدرج الناتج عن التقاعل بين نمطين من القيادة هما النمط المهتم بالعاملين، والنمط المهتم بالإنتاج فقط وهناك نمط قيادي نموذجي يحقق التوازن بين الاهتمام بالعلاقات الإنسـانية في التنظيم والتركيز على الإنتاج دون تفريط أو إفراط ، وهذا النمط هو ما يرتبط بالتمكين حيث أن القيادي يكون عنده استعداد للتوازن بين مـا تريده المؤسسـة لتحقيق أهدافها ومسا يريده العاملون بحيث لا يطغي جانب على جانب آخر والتمكين يوازن بين المستوي الجزئي (العامل ) والمستوي الكلي ( المؤسسـة ) · وتذكر مـي خميس أن نظريـة إدارة المـارد البشرية تتفق مـع تمكين العاملين وهنـاك علاقة متبادلة بينهما ، وكذلك يتفق التمكين مع القيادة التبادلية التي تعطي الاهتمام الكبير للتحفيز ، وكذلك القيادة التحويلية تعد أسـاس دور القائد المطلوب وجوده في عمليـة التمكين ـ كمـا أن تمكين العاملين يأخذ شكل الخطة الإستراتيجية التي تعنـي بوضـع الروئية الشـاملة للمؤسسـة وصياغة ورسم سياسـتها وتحديـ أهـافها ومواردهـا وإمكاناتها المتاحـة واتخـاذ القـرارات ، ويجب لإحـداث أي تغيير استراتيجي داخل المؤسسة استخدام واحد من ثلاثة أنواع رئيسية من عمليات التغيير الاستراتيجي هي إعادة الهندسة التي تركز على العمليات من اجل تحقيق تحسينات ملموبـة ، ثم إعادة الهيكلة والتي تعمل على المؤسسة وإدارتها مثل تخفيض عدد العاملين وكذلك تعمل على العمليات ، والثالث التجديد 


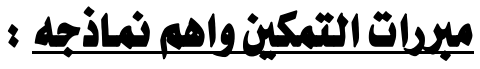

من المككن هنا ذكر أن أهم مبرر للتمكين الإداري هو استحالة أن يكون هناك فرد على رأس الس التس

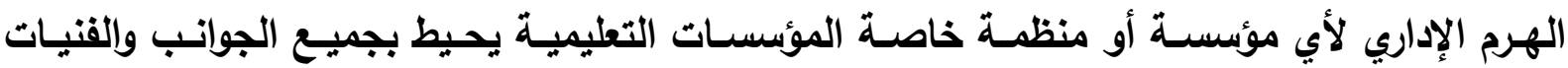

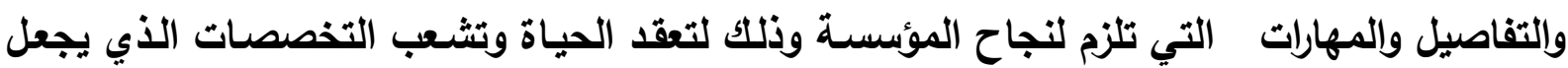
من الضروري الاستفادة من خبرات الجميع وقدراتهم في التغلب على المشكلات والمعوقات.

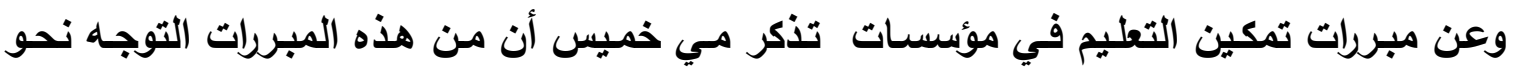

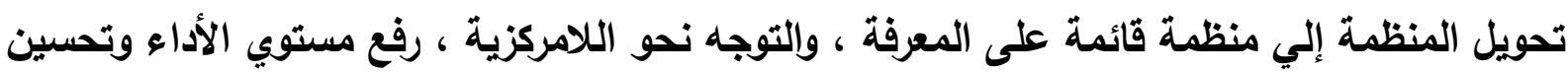
المخرجات ، حيث أن الإدارة تساوي القدرة + الدافعية + البيئة كمـا انه مـن مبررات التمكين تقليل الاعتمـاد على المستوي الأعلى في الإدارة وتحقيق التوازن الثخصي والمهني والرضا الوظيفي وزيادة الدافعية لاي العاملين ، وتنمية القدرة على تحمل المسئولية

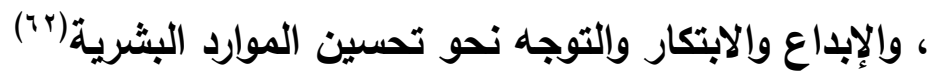

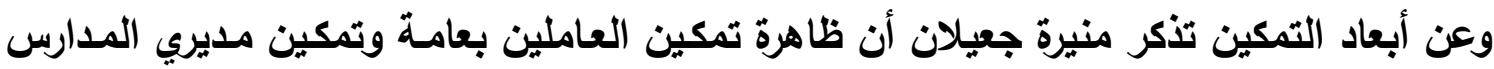

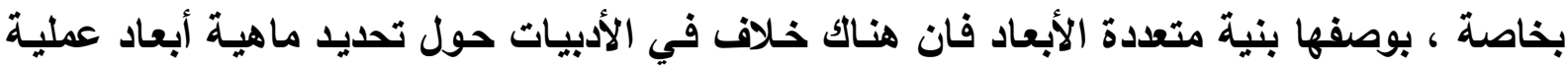

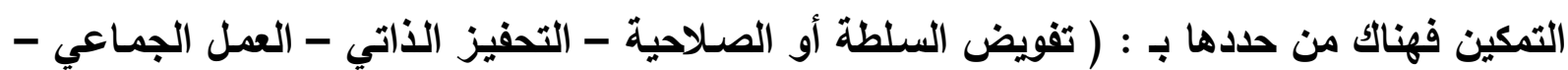

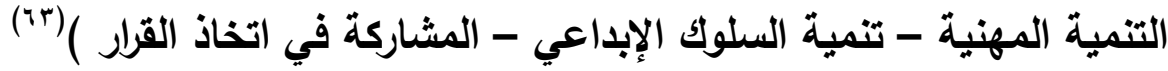
ومن الواضح أن هناك اختلاف في وجهات النظر حول أبعاد ومقومـات وأسس ومبادئ ومكونـات

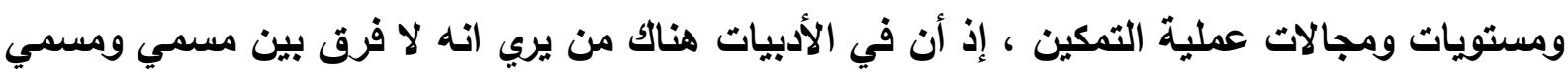
وهناك من يري بعض الفروق الفرعية ، وهناك من يري بعض الاتفاق في مـا يتعلق بهذه المسميات

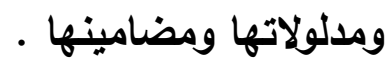

فبينمـا نجد جمـال أبو الوفـا يذكر تحت عندوان عناصر عمليـة التفويض ومبادئهـا أن عمليـة التفويض نتكون من ثلاثة عناصر : ( تحديد الواجبات والوظائف المطلوب أدائها - منح سلطات كافية التونة

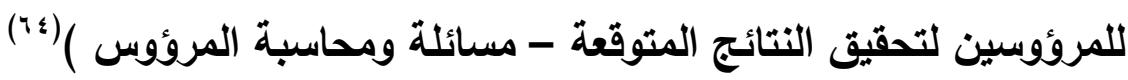
بينما نجد محمود أبو النور يتحدث عن أبعاد التمكين بأنها تتضمن ( اتخاذ القرار - النمو المهني

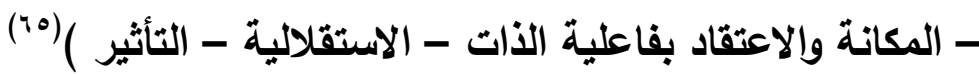
وريما يفسر الاختلاف السابق بان العلوم الإنسانية تزداد فيها تعددية الرؤى والتوجهات بمانها يؤئر

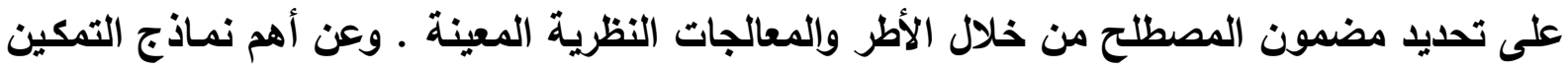

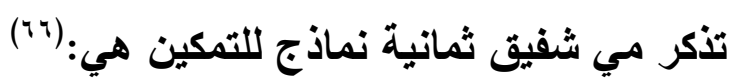

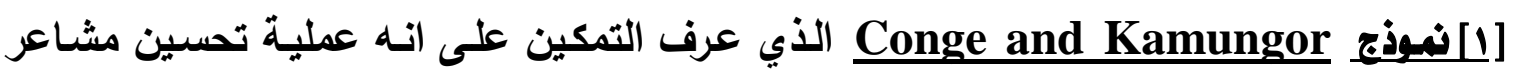
المقدرة الذاتية بين العاملين بالمنظمة من خلال تهيئة الظروف التي تساعد على السيطرة على العدل 
وزيادة المعلومات الرسمية ، والأساليب غير الرسمية لمدهم بمعلومات عن مقدرتهم الأاتية وحدد هذاء النموذج خمس مراحل لتنفيذ التمكين تشمل :

دراسة الظروف التي تثعر العاملين بالعجز - دراسـة التقتيات الإدارية وتوفير المعلومـات عن ال عاملين - تحديد نتائج تمكين العاملين - ملاحظة التغيير في سلوكيات العاملين - الاستمرار في دراسة الظروف التي تثنعر العاملين بالعجز

\section{Thomas and Velthouse المعرفي،}

وقد ركز هذا النموذج على محفزات السلوك لاي العامل وحدد سنة عناصر لإحداث التمكين وهي : بيئة الأحداث - تقييم الوظائف - تقييم سلوك العاملين - التقييم العام - أساليب التغيير - المدخلات . [ب] النموذج الثالث الأي رجع إلي عام ، 99 19 والذي يري أن أسـاس استمرار أيـة منظمـة يرجع إلـي الطاقة المحركة لها والمتمثلة في الأقراد ودافعيتهم للعمل - تلك الأفعية التي تثأثر بعمليات الإدارة الأساسية ويعوامل تتعلق بالأفراد ونوع الاتصال والمشاركة في التسيير والقرارات والتطوير . [ع] نموذج bowen and lower الذي حدد أريعة عناصر تلزم لوجود التمكين داخل المؤسسـة وهي توفير المعلومات عن الأداء داخل المؤسسة - عمل نظام المكافآت - تحسين المهارات والمعارف لا ي العاملين - توافر السلطة لدي العاملين في اتخاذ القرارات لاي العاملين التي تؤثر في الأداء داخل المؤسسة

[0] نموذج Spritzea والأي ركز على التمكين النفسي وحدد له أربعة أبعاد هي : ( المضمون - الاختصاص - حرية الاختيار - التأثير ) وكل الأبعاد حسب هذا النموذج مجتمعة في بناء التمكين النفسي ، كما أن تقدير الذات له اثر ايجابي على التمكين النفسي ـ لذلك فان التمكين النفسي لله اثر ايجابي على الفاعلية الأتية وعلى الابتكار [ج] نموذجـ Spector الذي يأخذ التمكين على انـه عملية تدريجية ، ويقوم هذا النموذج على قاعدة التولي والتخلي ، حيث التخلي يتم من خلال التحديد الدقيق للخطوط العامـة والأطر الإستراتيجية لعمل المؤسسـة ، ويتطلب أن تكـون المؤسسـة صـارمة حيـال تحديـ الأهداف وتحديـ اختصاصـات العاملين والتخلي : يقصد به تأهيل العاملين وحثهم على التصرف الفعال وذلك في مستوي التفاصيل • ويقدم هذا النموذج عدة أثكال للمؤسسات منها المؤسسة الأفقية التي تقل فيها المستويات الإداريـة ، ويوفر قدر من المرونة و مؤسسة الرقابة التي تتسم بالصرامة في العمل بما يؤثز سلبيا على طريقة العمل والمؤسسـات الفوضوية هي عكس مؤسسة الرقابـة ، والمؤسسـة الاتكالية التي تتسم بالخضوع حيث يقوم العامل بعمله دون التفكير في أية نتيجة لمسار عمله [V] نموذج Randolphs ] مالذي يري أن التمكين يتم من خلال مراحل ثلاثة هي : توفير كافة المعلومات اللازمة للعاملين للمشاركة الفعالة - توضيح الأهداف وتوضيح التدريب الفعال - مشاركة 


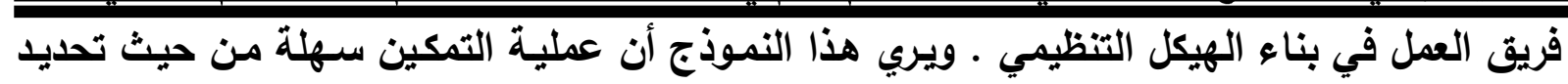
الأهداف ولكنها صعبة من حيث التنفيذ

[^] [ميوذج Hartline and Ferrell بجودة خدمة العمـلاء واللذي يتحقق من خلال عنصرين همـا : تمكين العاملين في المؤسسـة والثاني تقييم السلوك القائم للعاملين ووفق هذا النموذج فان تمكين العاملين يزيد من تحديد الدور ويقلل من الغموض لدي العاملين كما انه يؤثر على الفاعلية الأتية للعاملين . وقد لخصت مي خميس النقاط التي ركزت عليها النمـاذج السـابقة والتـي من أهمها : دراسـة بيئة المؤسسـة قبـل تنفيذ إسـتراتيجية التمكين ، ويجب إعداد العـلين قبـل تنفيذ التمكين وإعداد نظام للمكافآت على أساس فردي وتحديد المهمة وتوضيح الأداء المطلوب اتجازه وجعل العامل يشعر بحمل ، قدر من السلطة و المشاركة والتمكين يحقق قدر من تكيف العاملين مع بيئة المؤسسـة ويحقق التنفيذ لاي العاملين بأداء عملهم بأعلى كفاءة ممكنة كما انه يحقق الرضا عن العمل لايهم ( iv ) التمكين الإداري وعملية بناء القوة من خلال مدخل الثبكات Network Approach يذكر خالد حنفي أن ما أتاحته العولمـة من ثورة اتصالات ومعلومات وشبكات وانترنت ، وهواتف ذكية أسهم في اتجاه المجتمعات لنسـج روافد عبارة للحدود القومية وهذا يشكل الأسـاس الذي انبني عليه عالم الشبكات(^^) ويضيف حنفي انه في العالم الشبكي يدرك العاملون ( فرد - جماعة - دولة ) أن مسافاته اقتربت وقضاياه تداخلت ، وهو الأمر الذي يحد من القدرة على قيادته مركزيـا ، فلم يعد بإمكان أي فاعل بمفرده سواء أكان يعمل سمات رسمية ام غير رسمية ممارسـة التأثير في قضية أو

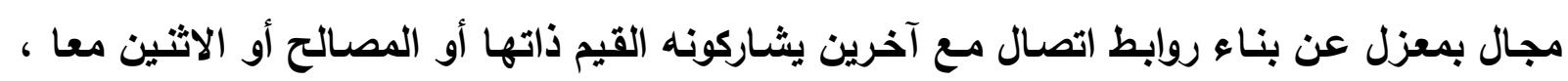
ويالتالي تحولت الشبكات إلي ما يشبه لغة العصر . وقد تعززت النظرة التشبيكية للتفاعلات في العالم مـع بزوغ نمط الاعتمـاد المتبـادل عند أصحاب النظرية الليبرالية والليبرالية الجديدة والذين أولوا اهتماما بتأثيرات الثركات العابرة للقومية في العلاقات الدولية ، فضلا عن المراجعات النقدية لطبيعة التنظيمات ذات الصيغة المركزيـة الهيراركية وجدوى نموذج القيادة والسيطرة(19) مما سبق تتضح العلاقة القويـة بين التمكين كمدخل أو نظريـة في طريقها للاكتمال (يستتل إلي ضرورة التخفيف من المركزية ) ونظرية الثبكات باعتبارها تنحو نحو اللامركزية ، كأساس لبناء القوة والتغيير هذا بثكل عام • وعلى المستوي الدولي حيث هناك أكثر من · r ألف شبكة عابرة للقومية

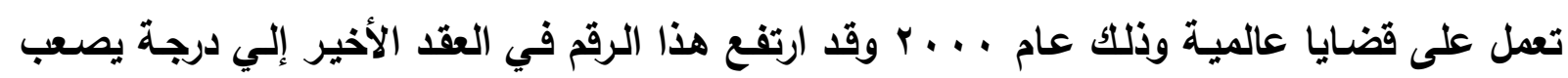
حصر (v) ويصبح الأمر أكثر أهمية داخل الدولة الواحدة ، وفي داخل منظومة التعليم وعلى الأخص في 


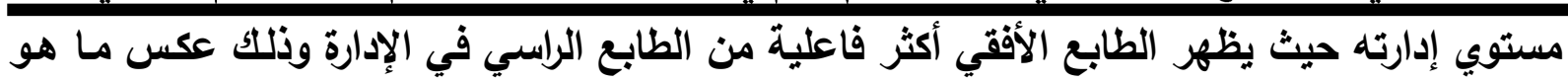
موجود إذ أن السائد هو الطابع الراسي وتلاشي الطابع الأفقي في الإدارة التعليمية . واثهـبكةمنــ Darn Barnue : تنطوي على عناصر رئيسية وهي العقد ( الجهاد فاعلة ،

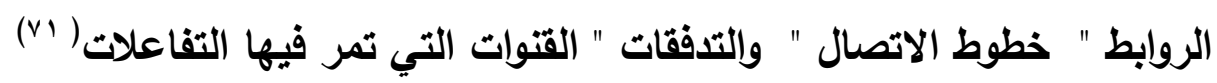
كما أن الهوف الأسناسي في بناء أي شبكة هو زيادة التأثير في قضية مـا وهذا يعني أنها تمثل وجها من أوجه عمليات بناء القوة ، ومن ثم تسـهم في عمليات التغيير ، فالشبكات والتغيير يغذي

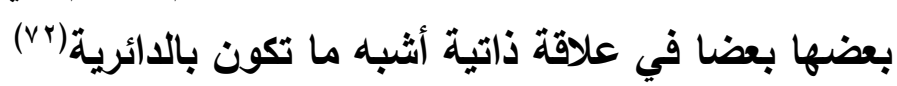
ويذهب حنفي إلي انه مثلما كان ظهور الثبكات ثمرة للتغيرات المتسارعة في عالمنـا فهي أيضا تثكل قوة دافعة للتغير فكلاهما ( أي الثبكات والتغيير يغذي بعضها بعضا في علاقة أشبه بالدائرية ، إذ أن التغيير في مفهومه العام هو انتقال أو تحول من وضع أو نظام أو حالة إلي أخري(Vr) ولمـا كان بان التعليم لا يعبر عن توقعات المجتمـع في مسـالة جودتـه وكفايتـه فـان هنـاك رغبـة ملحة ومتزايـدة ،

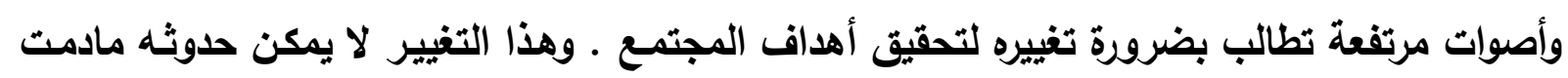
إدارة التعليم تتسم بالمركزية الشديدة ويالنظام الراسي الهرمي الأي لا يشارك الجميع في عملية إدارته . . ويالتالي فعملية التغيير لا يمكن إحداثها إلا بجهود جميع للعاملين في منظومة التعليم في إطار شبكي فعلي • والشبكات هي مجموعة من الترتيبات الحاكمـة تتضمن مبادئ وأهداف وقواعد واليات صنع القرار ( معلنة أو ضمنية ) تلتقي خلالها وحولها توقعات الفاعلين والشبكات هي شكل من أشكال

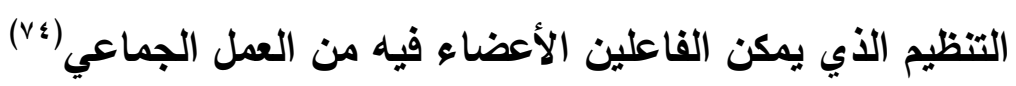
وهنا تلتقي عملية التمكين مع الثبكات ، إذ تذكر رانيا حسن خفاجـة أن الثبكات عبارة عن عقد وفواعل وروابط يمكن النظر إليها تحليلا من منظورين مختلفين ، أولهما يركز على الثبكات بحسبانها فواعل وثاتيهما يركز على الشبكات بحسباتها هياكل . وتتبع أهميـة هذا التقسيم من حقيقة أن معظم الكتابات في العلاقات الدولية ركزت على تحليل الثبكات على اثر الثبكات على البيئة التي تعمل فيها ممـا ترتب عليه إغفـال النظر إلي الثبكات على أسـاس أنها هياكل من شـانها التأثير في أعضـائها بالتمكين أو حتي التفويض والتقتيل(vo)

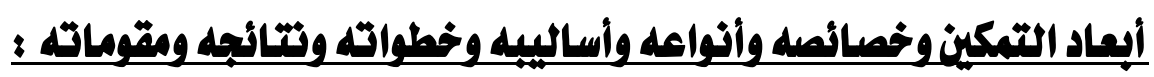

يلاحظ في بعض الأدبيات عن التمكين أن هناك من يخلط بين أبعاد التمكين وخصائصسه ومقوماتـه ، فقي الوقت الذي تذكر منيرة جعيلان أن هناك اتفاق عند من تطرقوا إلي أن أبعاد التمكين تثـمل

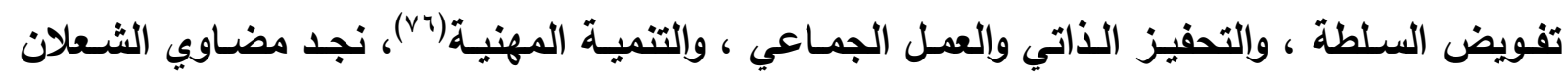
وسـهام كعكي تذكران أن التمكين يتميز ببعض الخصـائص التي منهـا : منح فرق العمل حريـة أداء مهامها وحل مشكلاتها ، بصورة فعالة ، واستثثار الكفاءات والقدرات الكامنة في الأداء ، والتقليل من الاعتمـاد على الإدارة في سـير العمل ، وزيـادة إنتاجية الأفراد ، وتحقيق الرضـا الوظيفي ، وارتفـاع 
الدافعية ـ وتضيف الثـعلان والكعكي أنـه لكي تتحقق أهداف التمكين لابد من توافر الثقة المتبادلة

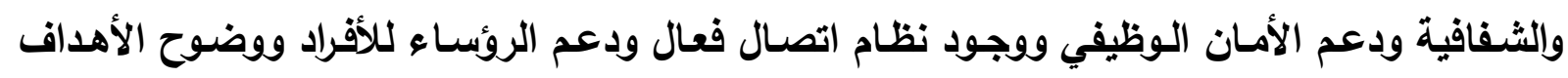
والروئية المستقبلية ، وتحديد القدرات التي يشارك فيها المرؤوسين ، ومعرفة الخطة الإستراتيجية المراد تنفيذها ، وتوافر نظام مناسب للحوافز ، وكسر الحواجز الرسـية السـلطوية ، والتدريب المستمر ،

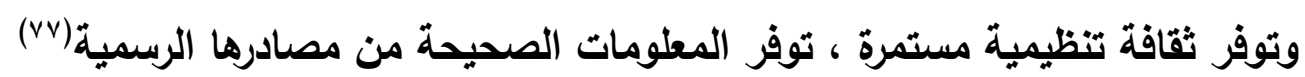
وعن أبعاد التمكين باعتباره برنامج التغيير يسبقه برامج متعددة لتهيئة المناخ المناسب لتحقيق

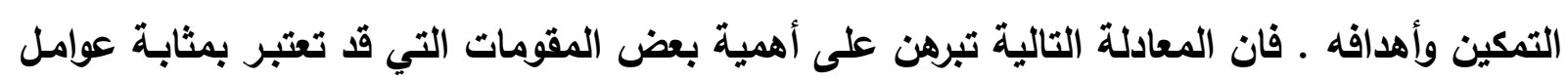
نجاح أساسية لنجاح التمكين في المنظمة وهذه المعادلة هي التمكين = القوة × المعلومات × المعرفة × المكافآت

وتري منيرة جعيلان انـه حسبما المعادلة السـابقة فان حاصل ضرب هذه العوامل أو المقومـات الأربعة يبين انه إذا كان أي عنصر من هذه العناصر يساوي صفر فان نتيجة التمكين الكلية سوف هـن تكون صفراً (v^) وتذكر مي خميس أن هناك من حدد أن هناك أربعة أبعاد للتمكين هي : - ( الأهمية - الكفاءة القدرة على الاختيار - التأثير ) في حين أن هناك من تناول ثماتية أبعاد للتمكين هي : ( الإدراك -

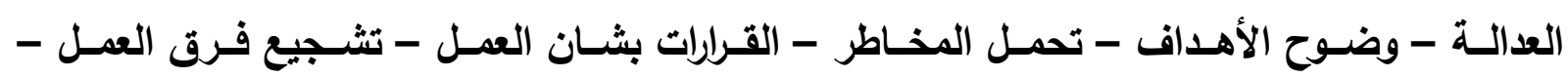

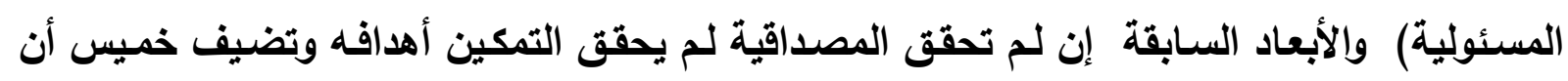
Spritezer تحقق سـبرايتر مـن صـة هذه الأبعـاد بـالرجوع إلـي عدد مـن مجـالات كعـم النفس وعلم الاجتمـاع والتعليم (va) وعن أنواع التمكين وهناك من حددها بمـا يلي : ( التمكين الإداري - التمكين المهاري - التمكين السياسـي ) إذ أن التمكين الإداري يعنـي نشـر صـلاحية اتخـاذ القـرار في جميـع أرجـاء المؤسسـة . والتمكين المهاري يعني نقل المهارات وتوفير المهارات التلازمة في العمل في إطار من الثقة والاعتمـاد على الذات والتمكين السياسي يعني القدرة على التأثير على صناعة القرار السياسـي وتضيف مي خميس أن هناك تصنيف آخر للتمكين يشمل ( التمكين الظاهري - التمكين السلوكي - تمكين العمل

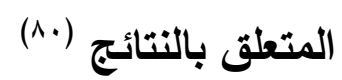
وعن أسـاليب التمكين الإداري المعاصرة تورد منيرة العزمسي ثلاثة أسـاليب للتمكين تحدث عنها ميمون Memon وهي : ( التمكين بواسطة القيادة ، التمكين للأفراد عن طريق التحفيز ، والتمكين الهيكلي • بالإضافة إلي أسلوب تمكين الفريق وأسلوب الأبعاد المتعددة في التمكين(1) وعن أسـاليب التمكين أيضـا يذكر محمود أبو النور أن هناك أسـاليب للتمكين تحدد فيما يلي : (أسـلوب التمكين الهيكلي - أسلوب التمكين مـن خـلال التحفيز - أسلوب التمكين مـن خـلال النمط 
القيادي - أسلوب التمكين من خـلال المسئوليات - أسلوب التمكين من خـلال الصـلاحيات - أسلوب فئولئ

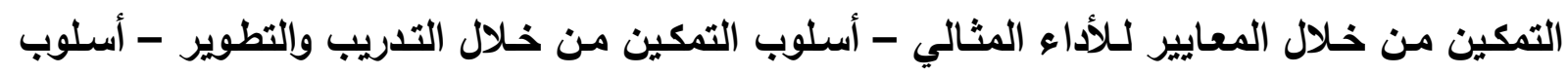
التمكين من خلال المعرفة والمعلومات - أسلوب التمكين من خلال التغذية الراجعة - أسلوب التمكين من خلال التقدير والاهتمام - أسلوب التمكين من خلال الاحترام - أسلوب التمكين من خـلال السماح

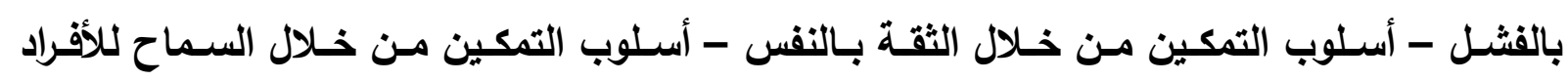
بالمجازفة والمخـاطرة ) ـ وعن خطوات التمكين الإداري يذكر أبو النور أن هنـاك من يري أن تطبيق هئق

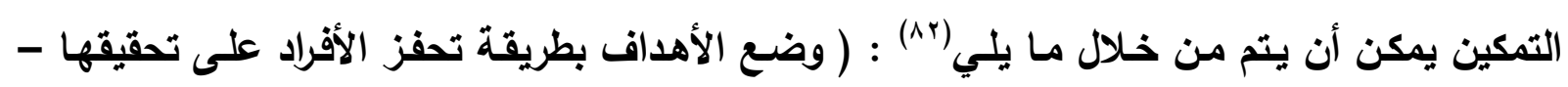
تعريف الأفراد بكيفية الحصول على الموارد اللازمة - إزالة العوائق البيروقراطية - إظهار الثقة في قدرة المرؤوسين على تحقيق الأهداف واتخاذ القرارات - زيادة فرص المشاركة في اتخاذ القرار - تدريب العـاملين على التفكير الإبـاعي وحل المشكلات - تأسيس فرق عمل طبيعيـة - تـوفير المعلومـات الكلازمـة - الاختيـار المناسب للأفراد - نقل التوقعات من خـلال خطط الأداء الإداريـة - توقع حدوث

مشاكل وأخطاء عند تطبيق التمكين ) وتذكر منيرة العزمي أن هناك من يقترح خطوات لتنفيذ التمكين تشمل ( (^^ ) ( تحديد أسباب الحاجة إلي التغيير - التغيير في سلوك المديرين - تحديد القرارات التي يشارك فيها المرؤوسين - تحديد فرق العمل - المشـاركة في المعلومـات - اختيار الأفراد المناسبين - توفير التدريب - الاتصسال لتوصيل التوقعات ووضع برنامج للمكافآت والتعزيز - عدم استعجال النتائج ) ولعل العرض السابق يثري ويسهم في تكوين نظرة أكثر شمولية للنقاط التي تمت معالجتها تحت هذا المحور.

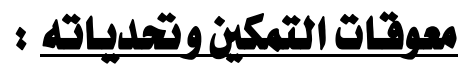

سبقت الإثارة إلي أهمية التمكين الإداري ، ومن الجدير بالذكر هنا الإثـارة إلـي أن هناك نتائج

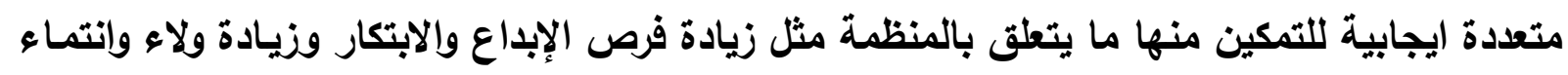
العاملين للمنظمة ، ومساعدة المنظمة في برامج التطوير و التجديد المستمر إلي الأحسن ورفع جودة الأداء ومنها مـا يتعلق بالموظفين ، حيث أن الموظف يشعر بذاته وقيمته عندما يجد أن لـه دور فعال في اتخاذ القرارت كما أن الثعور بالانتماء يحقق الاستقرار للموظف ، وينعكس التمكين بالإيجاب

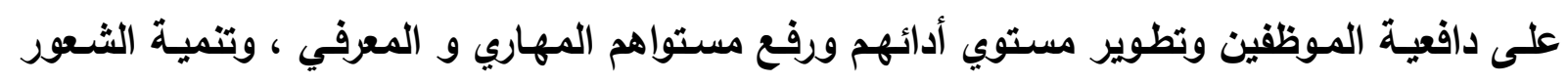

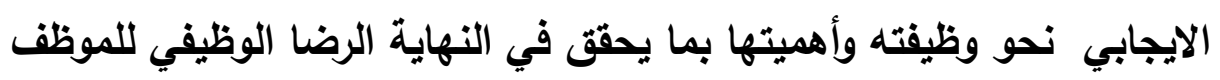
وكل ما سبق يمكن ألا يتحقق إذا لم يتم التظلب على المعوقات والتحديات التي تحول دون تحقيق التمكين ومن أهم المعوقات والتحديات التي تعوق تحقيق التمكين ما يرتبط بالجانب التشريعي والقانوني ، إذ أن حرفية الالتزام بالنص القانوني والغموض وكثرة وتضـارب القوانين واللوائح تحول دون وضوح الروئة ويالتالي تتاخل الاختصاصـات وتعجز المبادرات وتتخلص الحماسـة على العمل ـ وكذلك هناك 
معوقات ترتبط بعدم التحديد الاقيق والتوصيف المحدد للوظائف والمهام والمهن والأدوار التي ترتبط بكل مهنة ويكل وظيفة . منوة

وهناك من المعوقات ما يتعلق بالتنظيم الهرمي والمركزية الثديدة ومقاومـة التغيير وتضخم الذات وارتفاع مشاعر الأنا لاي القيادات ولاشعور بالتعالي والتميز لـي القيادات الإداريـة العليا بمـا يمنعها من منح التفويض والتمكين · وهنـاك معوقات تتعلق بنظام التحفيز وعدم شفافية وموضوعية وعدالة توزيع الحوافز ووضع التقارير • وكذلك هناك معوقات تتعلق بقصور التدريب وغياب النظام المحاسبي واضح ، فضلا عن غياب ثقافة التمكين وعدم القناعة به لضعف التعريف والوعي به ويأهميته ـ ثم أن هنـاك أيضـا معوقات تتعلق بنظام الاتصـالات وعدم وضـوح الأهداف وضـف العلاقات وعدم الإيمـان بأهمية فرق العمل وضعف مهارات المديرين ( ء^ ). وتذكر منيرة جعيلان أن هناك عوامل تؤدي إلي ضعف الشعور بالقوة منها قلة الشعور بالفاعلية وعدم السيطرة على العمل من قبل الموظفين ، ويالتالي إعاقة عملية التمكين ، وتتمثل هذه العوامل في عوامل تنظيمية ترتبط بسوء الاتصال والبيروقراطية وعوامل تتصل بنمط القيادة و عوامل ترتبط بنظام العوائد ، وعوامل تتصل بتقسيم العمل وعدم وضوح الأدوار. وهنـاك دراسـات ذكرت مجموعة من المعوقات تحديد التمكين منها ( محدوديـة فاعلية نظم إدارة الموارد البشرية ، مركزية اتخاذ القرارات ، ضمور القوانين وجمودها ، ضعف الثقة المتبادلة ، ضعف نظم المعلومـات و الاتصـالات ، عدم وجود الرغبة لدي المديرين في منح الصـلاحيات ، التركيز على النجاح الشخصي ، كثرة الصراعات والنزاعات ، اتخاذ القرارات على أسس الشخصية ، هرية البناء التظيمسي ، الخوف من تحمل المسئولية ، سرية المعلومـات ، اختلاف أهداف العاملين عن أهداف المؤسسة ، زيادة الأعباء المهنية ، تذني مستوي كفاءة العاملين ، محدودية البرامج التدريبية التلازمـة

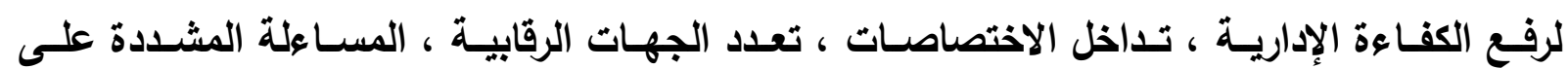

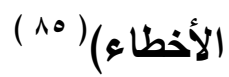

\section{( المحورالثالث )}

\section{ويتشمز الجحانب الميليداذي لللدراسية}

إجراعات اللدراسة الميليدانية وتشمل:

خطواتِ بناع الأداة ( الاستبـانة )

اعتمد الباحث في بناء الاستبانة على ما كتب بأدبيات تصميم الاستبانات وعباراتها وشروط كتابة وصياغة العبارات السلمية التي تعبر عن مـا يريده الباحث ، ثم معرفة الباحث بالواقع وملاحظه من واقع التمكين داخل بعض الإدارات الوسطي بالتعليم ومن خلال الاطلاع على بعض البحوث التي عالجت

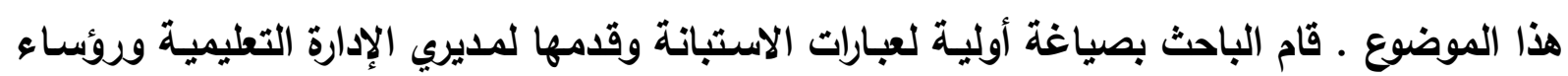
الأقسام ويعض قطاعات التعليم الأزهري في بعض المحافظات ويعض المتخصصين في مجال التقويم 
التمكن الإداري:مدخل لرفع كفاءة الأداء في مدارس التعليم العام في مصر (دراسة ميدانة) أ.م.د/ عبد السلام الشبراوي عباس التريوي والنفسي والإحصاء ـ ثم في ضوء الآراء المختلفة تم حذف وإضـافة بعض عبارات الإستبانة وذلك من خلال المراجعة و الالتزام بتوجيهات بعض الخبراء والمعينين بهذا الشأن وقام الباحث بتطبيق الاستمارة على عينة محدودة من مديري الإدارات والأقسام ، وهذا كان لله اثر في تعديل وحذف بعض داء العبارات التي اتسمت بالغموض والانغلاق على فهم أفراد العينة الاستطلاعية ـ وكذلك استفاد الباحث من الاستبانات المتعددة التي احتوت عليها بعض الاراسات السابقة في هذا المجال ـ وتوصل الباحث إلي الاستبانة في صورتها التهائية مشتملة على به عبارة غطت المحاور الأربع المشار إلبها سابقا

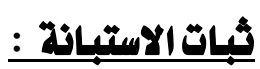
[1] تم حساب ثبات المستويات والاستبانة ككل بطريقة معامل ألفا كرونبـاخ لدي العينة الكلية ( ن =

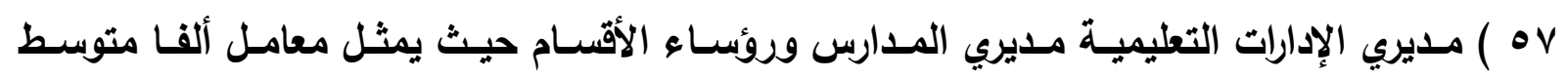
المعاملات الناتجة عن تجزئة الاستبانة إلي أجزاء بطريقة مختلفة ويذلك فانه يمثل معامل الارتباط بين أي جزأين من أجزاء الاستبانة وتتضح نتائج هذا التحليل من الجدول التالي رقم ( 1 ( ) معامل ثبات ألفا كرونباخ للأبعاد الأربعة والاستبانة ككل فئ وني

\begin{tabular}{|c|c|}
\hline 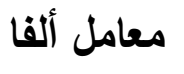 & البعـد البع \\
\hline .0707 & البعد المعرفي \\
\hline. $.71 Y$ & البعد المتعلق بالممارسة والتطبيق \\
\hline ת & بعد البيئة والمناخ الإداري \\
\hline$\cdot .7 \cdot \varepsilon$ & بعد المعوقات التي تحد من التمكين \\
\hline .710 & الدرجة الكلية للاستبانة \\
\hline
\end{tabular}

ويتضح من الجدول السابق رقم ( 1 ) ثبات الاستبانة ككل والمستويات الفرعية المتمثلة للاستبانة [ب] أ- تم حساب الصدق الكلي لاستبانة الموجهة لمديري الإدارات التعليمية ورؤسساء الأقسـام حول أرائهم في التمكين الإداري المتاح لهم والتمكين الأي يتيحونه لمرؤوسيهم عن طريق حساب معاملات الارتباط

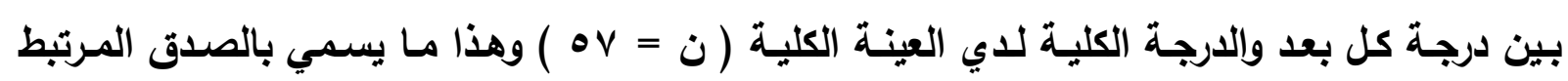
بالتكوين أو المفهوم كما هو موضح بالجدول التالي رقم (r ) جدول (r)

معاملات الارتباط بين الأبعاد الأربعة للتمكين والارجة الكلبة للاستبانة :

\begin{tabular}{|c|c|}
\hline الارجة الكلية & معاملات الارتباط \\
\hline $.00 \mathrm{~V}$ & البعد المعرفي \\
\hline 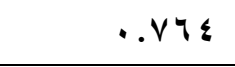 & البعد المتعلق بالممارسة والتطبيق \\
\hline. $.7 \vee r$ & بعد البيئة والمناخ الإداري \\
\hline. $.0 \mathrm{Vr}$ & بعد المعوقات التي تحد من التمكين \\
\hline
\end{tabular}




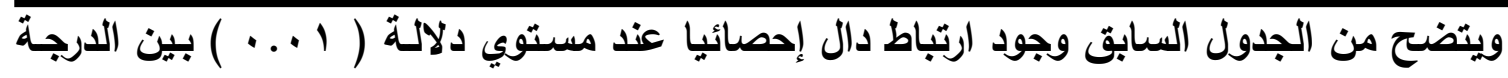
الكلية على الاستبانة والبعد من الأبعاد الأريعـة المكونـة للاستبانة ، ممـا يشسير إلـي اتسـاق البنـاء

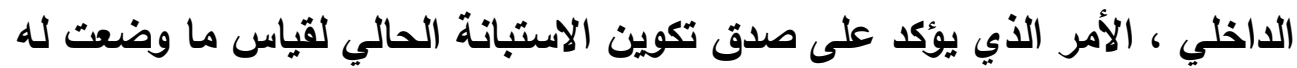

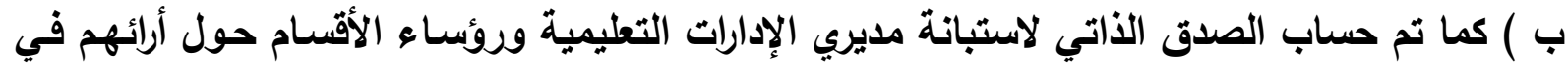

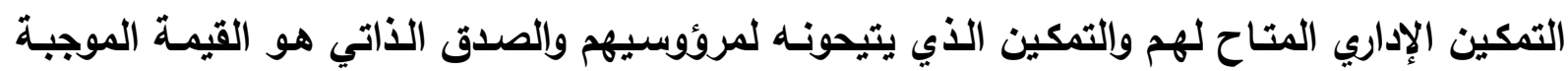

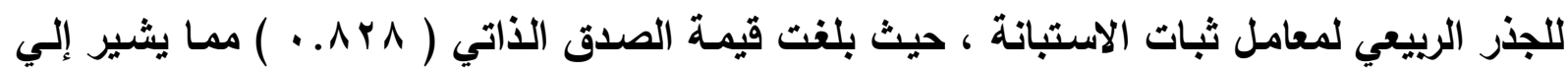
صدق الاستبانة

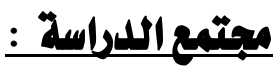

تمثُل مجتــع الدراسـة في مـديري الإدارات التعليميـة وروئسـاء الأقسـام بهذه الإدارات في بعض

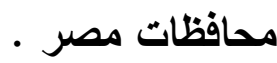

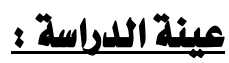

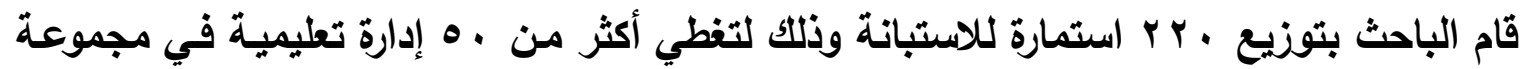

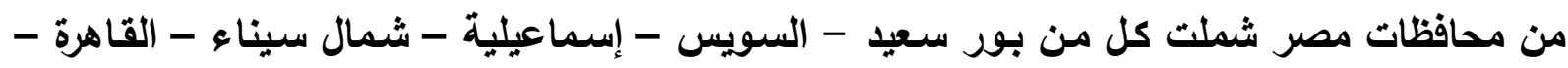

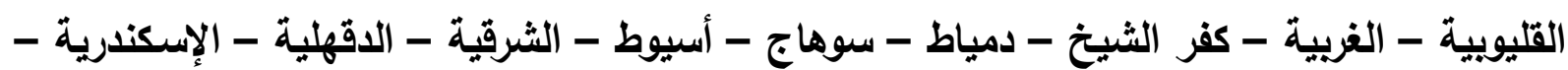

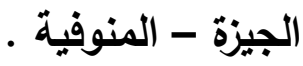

وكانت الاستمارة عبارة عن استبانة تثتمل على به عبارة غطت مجموعة محاور أريعة تتطلق

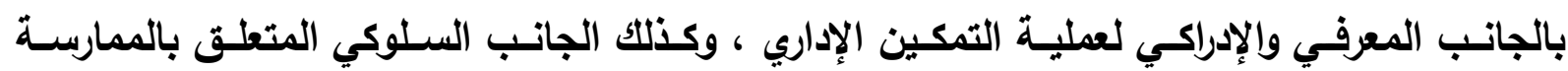
والجانب المتعلق بالبيئة والمناخ الإداري وأثره على التمكين ، والبعد الرابع بعد المعوقات التبات التي تحد من التمكين

\section{حادود اللدراسة :}

اقتصرت الاراسـة على مديري الإدارات التعليميـة ومديري الأقسـام بالمحافظات التي تمت الإثـارة

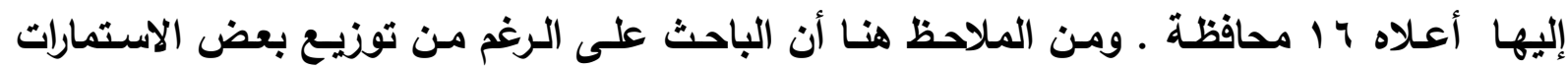

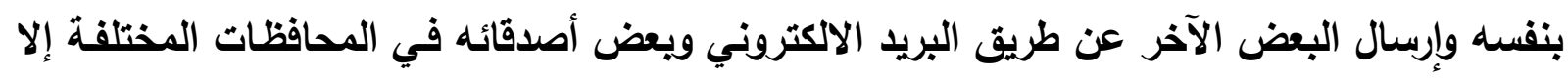

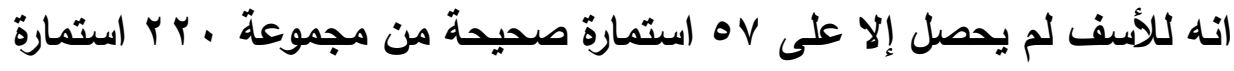

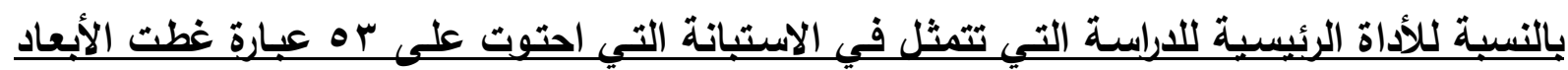

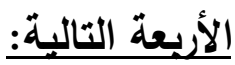
البعد المعرفي : وخصته العبارات أرقام ( 1 ( 1 -

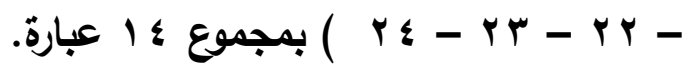




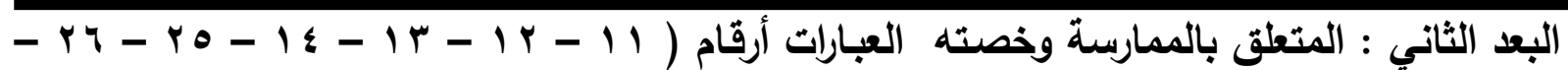

$-0 \cdot-\varepsilon q-\varepsilon \Lambda-\leqslant V-\varepsilon q-\varepsilon 0-\varepsilon \varepsilon-\varepsilon r-\varepsilon r-\varepsilon 1-\varepsilon \cdot-r q-r V-r 0$

(or - 01

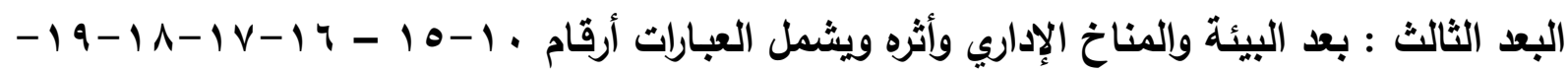

$$
\text { צr-r }
$$

البعد المتعلق بالمعوقات : وغطته العبارات أرقام V

$$
\text { عبارات }
$$

سبقت الإثـارة أن الثـق الميداني من هذه الاراسـة استهـف توصيف واقع التمكين الإداري في مستوي الإدارة الوسطي في مصر الذي يقصد بـه مستوي مديري الإدارات التعليمية ورؤسساء الأقسـام بتلك الإدارات وكذلك الوقوف على مستوي ادارك مفهوم وأبعاد عملية التمكين لدي عينة الدراسـة وذلك للاستفادة منها في صياغة مجموعة من المقترحات والتوصيات التي يمكن من خلالها تفعيل التمكين في هذا المستوي الإداري الهام وقد سبقت الإثـارة عند الحديث في مطلع الاراسـة الراهنـة إلـي بنـاء

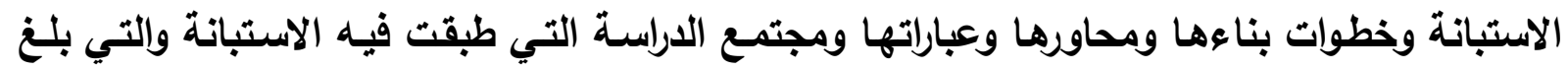
أكثر من نصف محافظات مصر و تمت الإثـارة إلي خطورة عدم الاهتمام من قبل العاملين بالإدارات التعليمية بجدوى الدراسات العملية والميدانية ، و عدم الاكتراث من الاستبانات في الكشف عن الواقع ومن ثم محاولة علاجه ، إذ أن الباحث وزع · r استمارة فلم تبلغ الاستمارات الصحيحة التي اعتمد عليها سوي V ه استمارة وهذا تدني خطير في مستوي إدرالك ووعي أهمية الدراسات العلمية والأكاديمية لاي القائمين على الإدارة التعليمية في مجالها التطبيقي ، وهذا يجعل الباحث يوصسي بضرورة الاهتمام براب الصدع وجبر الفجوة بين القائمين على الجانب النظري والأكاديمي والبحثي ويبين العاملين في الواقع التجريبي العملي ، إذ لا غني لأحدهما عن الآخر ، فمن المعروف أن النظريـة تهدي التطبيق والتطبيق يثري النظريـة ـ وقد تمـت عمليـات تفريـغ الاسـتجابات أفراد العينيـة والمعالجـة الإحصـائية باستخدام برنامج SPss/ps+ وذلك لحساب التكرارات والنسب المئويـة والتقدير الرقمي واللوزن النسبي كا` وذلك للتأكيا من صحة فروض الاراسة الميدانية .

\section{المجورالرابع}

\section{( ويتضشن ثتائج اللدراسة واهم التوصياتو الثقتز حات )}

نتائج الاربسة المبدانية: جاءت نتائج الدراسة الميدانية كالتالي : فيمـا يتعلق بالفرد الأول الذي ينص على انسه لا توجد فروق ذات دلالة إحصائية بين استجابات أفراد العينة على عبارات البعد المعرفي. 


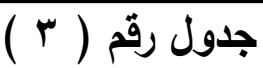

\begin{tabular}{|c|c|c|c|c|c|c|c|c|c|c|c|}
\hline \multirow{3}{*}{ 牙 } & \multirow{3}{*}{ 勇哥 } & \multirow{3}{*}{ كاץ } & \multirow{3}{*}{ 可雨 } & \multirow{3}{*}{ 司事 } & \multicolumn{6}{|c|}{ أبعاد الاستجابة } & \multirow{3}{*}{$\underset{: 0}{\stackrel{9}{9}}$} \\
\hline & & & & & \multicolumn{2}{|c|}{$y$} & \multicolumn{2}{|c|}{ إلي حد ما } & \multicolumn{2}{|c|}{ نعم | نعم } & \\
\hline & & & & & المئوية & التكرا & المئوية & التكرا & المئوية & التكرار & \\
\hline دالة & 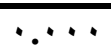 & 09.7 & $r \vee \wedge . q$ & 109 & 1.1 & $T$ & $1 V .0$ & 1. & $\Lambda \cdot . v$ & $\sum 7$ & $T$ \\
\hline دالة & $\because \cdots$ & $r 0 . r$ & YTr.l & 10. & 0.4 & $\mu$ & rq.r & 10 & $7 \Lambda . \xi$ & $r q$ & r \\
\hline دالة & $\because \cdots$ & rq.r & Y 79.7 & $10 Y$ & r.0 & $r$ & $r \bar{r}$ & 10 & $V \cdot . r$ & $\varepsilon$. & $r$ \\
\hline دالة & $\because \cdots$ & $r \leqslant . \varepsilon$ & rqr.l & 10 & T.0 & $r$ & $r q . \wedge$ & IV & $74 . V$ & $r \wedge$ & $\varepsilon$ \\
\hline دالة & $\because \cdots$ & rY & ro4.1 & $1 \leqslant 7$ & IY.r & $\mathrm{V}$ & $19 . r$ & 11 & $7 \wedge . \varepsilon$ & rq & 0 \\
\hline دالة & $\because \cdots$ & $1 \leqslant . V$ & rVO.\& & $10 \mathrm{~V}$ & . & . & $r \leqslant .7$ & $1 \leq$ & $\overline{V 0 . \varepsilon}$ & $\varepsilon r$ & 7 \\
\hline دالة & $\because \cdots$ & $\Gamma \varepsilon$. & YTr.I & 10. & T.0 & r & ५ १.१ & IV & $74 . \mathrm{V}$ & $r \Lambda$ & $\bar{v}$ \\
\hline دالة & $\because \cdots$ & 47.9 & YTr.l & 10. & $\mathrm{~V}$ & $\varepsilon$ & YY.A & $1 \pi$ & $\overline{V \cdot . r}$ & $\varepsilon$ & $\Lambda$ \\
\hline دالة & $\because \cdots r$ & 11.8 & rro." & IT & IY.Y & $\mathrm{v}$ & 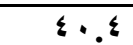 & Tr & $\xi V . \xi$ & TV & 9 \\
\hline غير دالة & $\because \times 7$ & 0.1 & $1 \wedge V . V$ & $1 . V$ & $r r . r$ & 19 & $\$ 0.7$ & rq & Y1.1 & Ir & r. \\
\hline دالة & $\because \cdots$ & $1 \wedge . \wedge$ & $r \cdot \theta . r$ & $11 \mathrm{~V}$ & $r 0.1$ & $r \cdot$ & $r \leqslant . T$ & $1 \varepsilon$ & $r 9.7$ & $r r$ & YI \\
\hline غير دالة & .197 & $r . r$ & YIY.r & $|r|$ & $r 1.7$ & 11 & $r \leqslant . T$ & $1 \leq$ & $\varepsilon r .9$ & ro & YY \\
\hline غير دالة &. .794 &..$V$ & $r \cdot \Lambda . V$ & 119 & $r q . \wedge$ & IV & $r 1.7$ & 1 & $r \wedge .7$ & YY & $r r$ \\
\hline دالة & $\because r$. & IY.r & Yrצ.A & $1 \% 0$ & $1 V .0$ & 1. & Y^.1 & 17 & $0 \leqslant . \leqslant$ & $\mu_{1}$ & $r \leqslant$ \\
\hline
\end{tabular}

من الجدول يتضـح انـه توجد فروق دالـة بين تكرارات استجابات أفراد العينـة لجميع عبـارات البعد

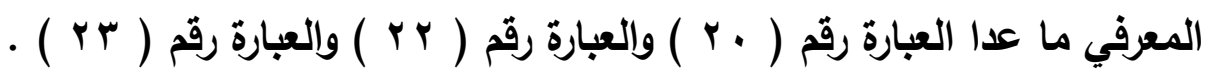

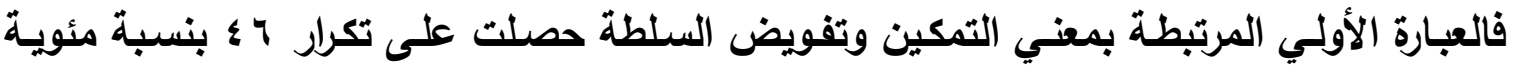

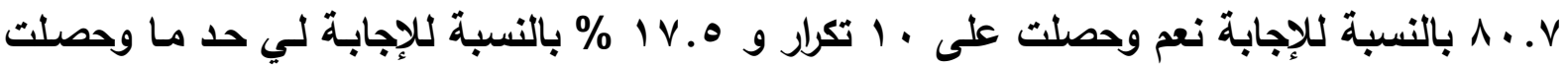

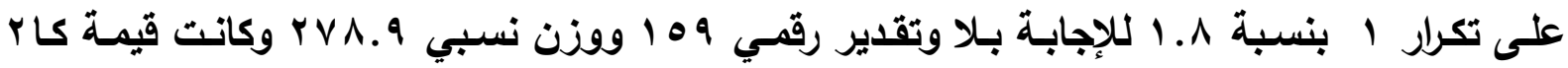

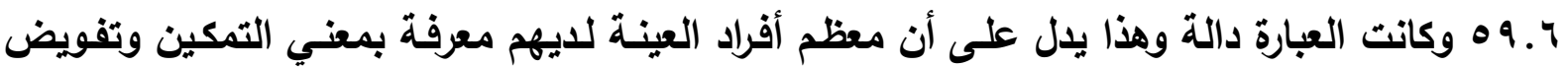

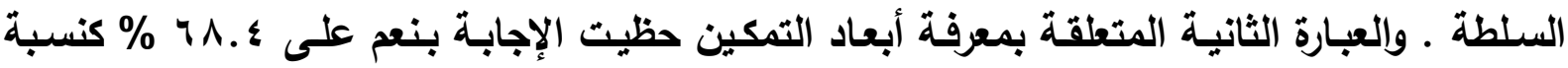

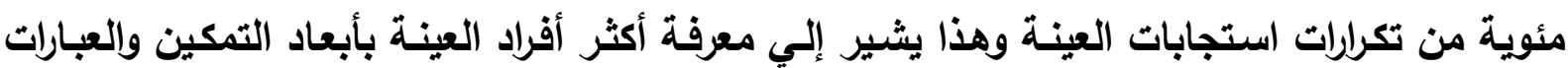

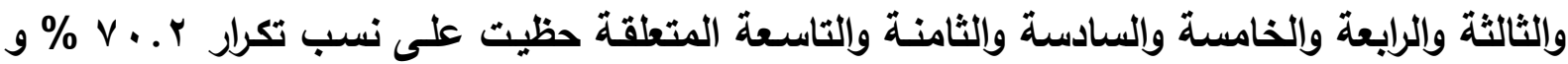

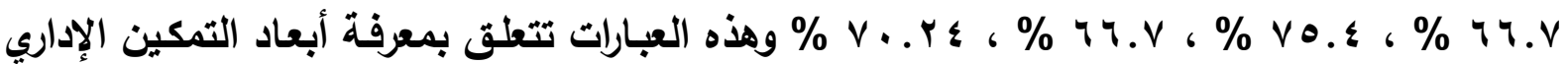
من تفويض السلطة والتحفيز الذاتي والعمل الجماعي وتنمية السلوك الإبداعي والمشاركة في اتخاذ القرارات وهذا يال من خلال القراءة التحليلية للأرقام الموجودة لكل عبارة في الجدول تثثير إلي ضعف

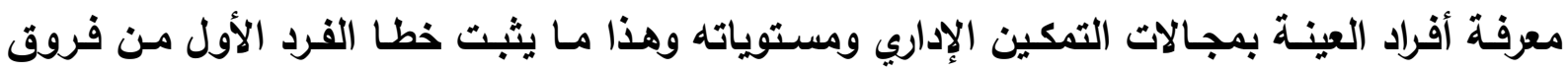

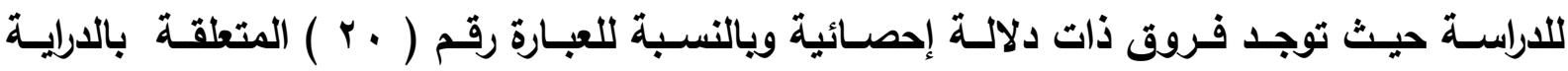

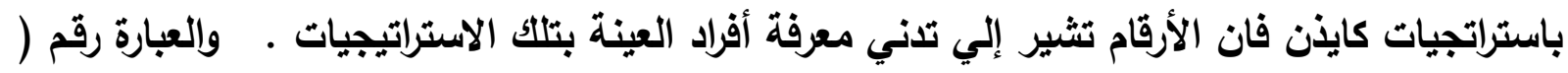

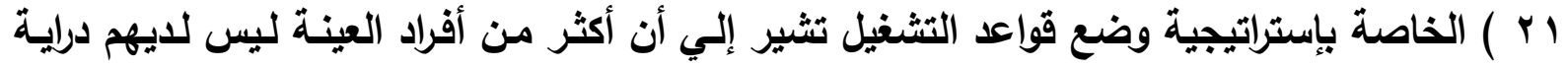

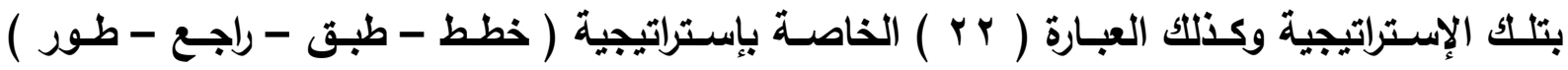

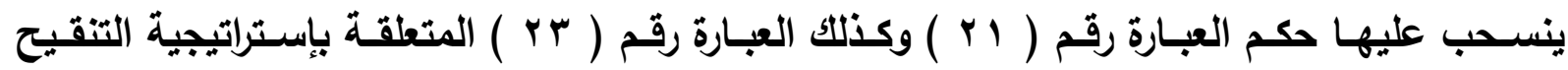


التمكين الإداري:مدخل لرفع كفاءة الأداء في مدارس التعلم العام في مصـ (دراسة ميدانة) أ.م.د/ عد السلام الشبراوي عباس

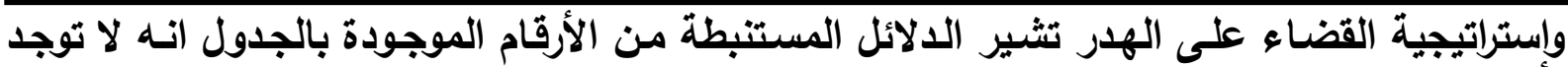
فروق دالة بين تكرارات استجابات أفراد العينة فيما يتعلق بتلك العبارات

فيما يتعلق بنتائج الفرد الثاني الذي ينص على انـه لا توجد فروق دالـة بين تكرارات استجابات أفراد العينة على عبارات البعد المتعلق بممارسة وتطبيق التمكين والذي يعبر عنها الجدول رقم ( ؛ ) التالي

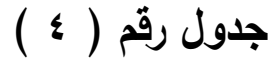

\begin{tabular}{|c|c|c|c|c|c|c|c|c|c|c|c|}
\hline \multirow{3}{*}{ 唁 } & \multirow{3}{*}{ 雪 } & \multirow{3}{*}{ كاץ } & \multirow{3}{*}{ 可牙 } & \multirow{3}{*}{ 氞事余 } & \multicolumn{6}{|c|}{ أبعاد الاستجابة } & \multirow{3}{*}{ 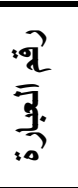 } \\
\hline & & & & & \multicolumn{2}{|c|}{ ע } & \multicolumn{2}{|c|}{ إلي حد ما } & \multicolumn{2}{|c|}{ نعم } & \\
\hline & & & & & المئويبة & التكرا & المئوية & التكرا & المئويبة & التكرار & \\
\hline دالة & $\because \cdots 1$ & 15 & INr.z & $1 \cdot \varepsilon$ & $r 1.7$ & 11 & $0 \leqslant . \varepsilon$ & $r 1$ & $1 \varepsilon$ & $\Lambda$ & 11 \\
\hline غير دالة &. .197 & $\overline{r . Y}$ & $1 A \cdot . V$ & $1 . r$ & $\varepsilon r .9$ & ro & $r 1.7$ & 11 & $r \leqslant .7$ & $1 \varepsilon$ & Tr \\
\hline غير دالة & $\cdot .44$ & $r$ & $191 . r$ & 114 & rq.1 & IV & $\varepsilon r .1$ & $r \varepsilon$ & $r \wedge .1$ & 17 & $1 T$ \\
\hline غير دالة & . & T.Y & $r 1.0$ & $T r$. & $r \leqslant .7$ & $1 \varepsilon$ & $\varepsilon \cdot . \varepsilon$ & rr & $r 0.1$ & $r$. & $1 \leq$ \\
\hline دالة & $\because \cdots$ & TY.Y & $r 0.11$ & $T \leqslant r$ & $\bar{V}$ & $\xi$ & $r 0.1$ & $r_{.}$ & $0 V .9$ & $r r$ & Yo \\
\hline دالة & $\because \cdots$ & $r \cdot .9$ & $r \leqslant 9.1$ & $T \leqslant Y$ & $1 \cdot$. & 9 & rq.1 & IV & 09.7 & $r \varepsilon$ & Y4 \\
\hline دالة & $\because \cdots v$ & 9.1 & YYY.r & $1 \% 9$ & $1 \leqslant$ & $\Lambda$ & $\leqslant 0.7$ & Yq & $\varepsilon \cdot . \varepsilon$ & $r r$ & ro \\
\hline دالة & $\because \cdots$ & $r \cdot . v$ & 109.7 & $1 \leqslant 1$ & $0 . r$ & $r$ & rq.1 & IV & $7 \leqslant .9$ & $r v$ & $r v$ \\
\hline دالة & $\because+1$ & $1 \leq$ & $r r{ }^{2}{ }^{\prime}$ & 174 & 1.00 & 7 & $\varepsilon \cdot . \xi$ & $r \mu$ & $\varepsilon 9 . \xi$ & $r \Lambda$ & rq \\
\hline دالة & $\because \cdots$ & 57.9 & Y07.1 & $1 \leqslant 7$ & $0 . r$ & $r$ & rr.r & 19 & 71.8 & ro & \&. \\
\hline دالة & $\because .^{\prime}$ & 7.8 & YYY.A & IrV & $1 V .0$ & 1. & $\varepsilon Y .1$ & $Y \varepsilon$ & $\varepsilon \cdot . \varepsilon$ & Yr & \&1 \\
\hline غير دالة & $\because \cdot V 7$ & 0.1 & 180.2 & $1 \cdots$ & 20.7 & YT & $r r . r$ & 19 & $r 1.1$ & IY & $\varepsilon r$ \\
\hline دالة & $\because \cdots \wedge$ & 9.0 & YI $\varepsilon_{.}$ & IrY & $1 V .0$ & 1. & 0.99 & rq & 51.7 & 11 & $\varepsilon r$ \\
\hline غير دالة &..$\wedge 1$ & $\because \varepsilon$ & $r \cdot r .0$ & 117 & $r r . r$ & 9 & $r q .1$ & IV & $r 4.1$ & YI & 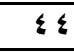 \\
\hline دالة & $\because .47$ & 7.7 & YYY.r & 149 & $1 V_{0} 0$ & 1. & $r \wedge . \tau$ & YY & $\varepsilon r . q$ & ro & $\leqslant 0$ \\
\hline دالة & $\because \cdots \leq$ & $1 . .1$ & $1 V V_{.1}$ & 1.1 & Or. $T$ & $r$. & 18.0 & 1. & r9.1 & IV & \& \\
\hline دالة & $\because \cdots$ & $\varepsilon r$. & Y77.7 & $10 Y$ & $V$ & $\varepsilon$ & $19 . r$ & 11 & $V r . V$ & $\varepsilon Y$ & $\varepsilon V$ \\
\hline دالة & $\because \cdots$ & $1 \wedge .1$ & $r \leqslant 0.7$ & $1 \varepsilon$. & Tr.r & $\mathrm{V}$ & Y৭.१ & IV & $0 V .9$ & $r r$ & $\leqslant 1$ \\
\hline دالة & $\because \cdots$ & rq & $Y 0 \cdot . \Lambda$ & $1 \leqslant r$ & $1 \varepsilon$ & $\Lambda$ & $r 1.1$ & Ir & $7 \leqslant .9$ & $r v$ & $\leqslant 9$ \\
\hline دالة & $\because \cdots$ & $r \cdot . r$ & $10 V .1$ & 9. & 71.2 & ro & $19 . r$ & 11 & $19 . r$ & 11 & 0. \\
\hline دالة & $\because \cdots$ & $\Delta \wedge . \Lambda$ & rVV.1 & 101 & r.0 & $\bar{r}$ & 10.1 & 9 & $\Lambda \cdot . V$ & $\{7$ & 01 \\
\hline دالة & $\because \cdots$ & $\varepsilon \cdot . V$ & r४^.\& & 104 & 1.1 & 1 & $r \wedge .1$ & 17 & $V \cdot . r$ & $\varepsilon \cdot$ & $O Y$ \\
\hline
\end{tabular}

ويالقراءة التحليلية لالالات الأرقام الموجودة لكل عبارة من عبارات البعد المتعلق بالممارسـة والتطبيق

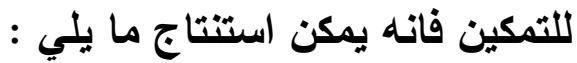

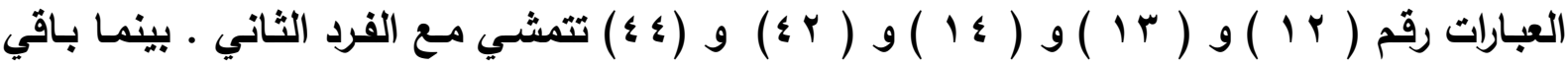
عبارات هذا البعد لا تحقق صحة هذا الفرض

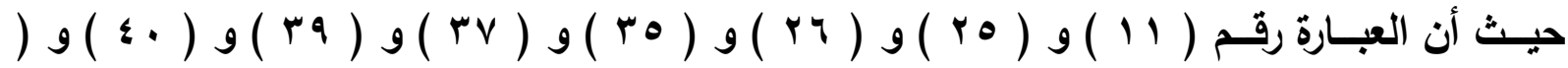
( ) ( ) ( rه ) كاتت دالة إحصائيا وهذا يؤكد عدم وجود فروق دالة بين تكرارات استجابات أفراد العينة على عبارات هذا البعد المتعلق بالممارسة والتطبيق 
التمكين الإداري:مدخل لرفع كفاءة الأداء في مدارس التعلم العام في مصر (دراسة مبدانة) أ.م.د/ عبد السلام الشبراوي عباس

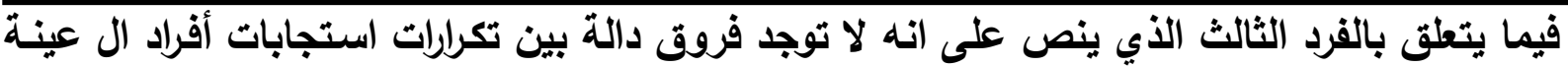
على عبارات بعد البيئة و المناخ الإداري وأثره على التمكين فان الجدول رقم ( • ) التالي يوضـح تلك

النتائج

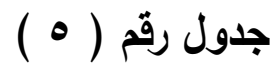

\begin{tabular}{|c|c|c|c|c|c|c|c|c|c|c|c|}
\hline \multirow{3}{*}{ 武 } & \multirow{3}{*}{ 产高 } & \multirow{3}{*}{ كاץ } & \multirow{3}{*}{ 可雨 } & \multirow{3}{*}{ 司事 } & \multicolumn{6}{|c|}{ أبعاد الاستجابة } & \multirow{3}{*}{$\underset{: 0}{\stackrel{9}{3}}$} \\
\hline & & & & & \multicolumn{2}{|c|}{$\bar{y}$} & \multicolumn{2}{|c|}{ إلى حد ما } & \multicolumn{2}{|c|}{ نعم } & \\
\hline & & & & & المئوية & التكرا & المئوية & التكرا & المئويبة & التكرار & \\
\hline دالة & $\because \cdots 1$ & $14 . .0$ & $r r \Lambda_{.7}$ & 114 & IY.r & $\bar{v}$ & $r 9.1$ & YI & 0.99 & $7 q$ & 1 . \\
\hline دالة & $\because \cdots$ & $r \leqslant .9$ & $Y 10 . V$ & Trr & $1 . .0$ & 7 & 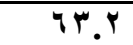 & ד & Y..\% & 10 & 10 \\
\hline دالة & $\because \cdots r$ & $11 . r$ & $r M 1.0$ & TrY & TY.r & $\mathrm{V}$ & $\leqslant r . q$ & ro & $\leqslant r .9$ & ro & 17 \\
\hline غير دالة & $\cdot 1 Y \wedge$ & $\varepsilon .1$ & IA . $Y$ & 1.0 & $r 4 . \wedge$ & YI & \&Y.। & $r \varepsilon$ & Y.1. & IY & IV \\
\hline دالة & $\because \cdots r$ & 11.2 & rro.9 & $1 \% \varepsilon$ & Tr.r & $\mathrm{V}$ & $\varepsilon \cdot . \varepsilon$ & $r \mu$ & $\varepsilon V_{.} \varepsilon$ & $r V$ & 11 \\
\hline دالة & $\because \cdots$ & IV.V & YYY.A & ITV & $1 . .0$ & 7 & 09.1 & $r r$ & $r r . r$ & 19 & 19 \\
\hline دالة & $\because \cdots$ & 19.4 & YYI..0 & $1 \% 4$ & $1 . .0$ & 7 & $0 V^{\circ} .9$ & $r \mu$ & 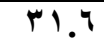 & 11 & rq \\
\hline دالة & $\because \cdots$ & 17.8 & $r \leqslant Y .11$ & 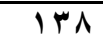 & $\Lambda . \Lambda$ & 0 & $\varepsilon . . \xi$ & rT & $0 . .9$ & rq & $r \Lambda$ \\
\hline دالة & $\because \cdots$ & 11 & $r \leqslant r .11$ & $1+1$ & $\bar{v}$ & $\xi$ & $\leqslant r . q$ & ro & $\leqslant 9.1$ & $r \wedge$ & Or \\
\hline
\end{tabular}

بالقراءة التحليلية لأرقام هذا الجدول يلاحظ أن جميع العبارات جاءت نسبها دالة مـا عدا العبارة رقم ( 1 ) ) كانت غير دالة وهذا يدل على أن الغالبية العظمي لعبارات البيئة والمناخ الإداري وأثره على التمكين تلل على أن هناك فروق دالة بين تكرارات استجابات أفراد العينة على تلك العبارات مـا عدا العبارة رقم ( IV ) وهو ما يعني أن جميع العبارات ما عدا عبارة واحدة لا تحقق صحة القرد الثالث نتائج الفرد الرابع المتعلقة الذي ينص على انه لا توجد فروق دالة بين تكرارات استجابات أفراد العينة على عبارات بعد المعوقات التي تحد من التمكين ويبينها الجدول رقم ( 1 ) التالي

جدول رقم (

\begin{tabular}{|c|c|c|c|c|c|c|c|c|c|c|c|}
\hline \multirow{3}{*}{ 牙 } & \multirow{3}{*}{ 炙言 } & \multirow{3}{*}{ كاץ } & \multirow{3}{*}{ 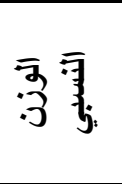 } & \multirow{3}{*}{ 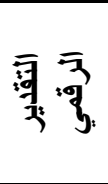 } & \multicolumn{6}{|c|}{ أبعاد الاستجابة } & \multirow{3}{*}{ 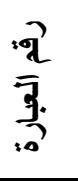 } \\
\hline & & & & & \multicolumn{2}{|c|}{$y$} & \multicolumn{2}{|c|}{ إلي حد ما } & \multicolumn{2}{|c|}{ نعم } & \\
\hline & & & & & المئوية & التكرا & المئويبة & التكرا & المئوية & التكرار & \\
\hline دالة & $\because \cdots$ & 17.8 & $r r 1.0$ & $T r Y$ & $\Lambda . \wedge$ & 0 & 0.99 & rq & $\varepsilon \cdot . \varepsilon$ & $\overline{r r}$ & $\overline{r V}$ \\
\hline دالة & $\because \cdots$ & $Y \leq$ & $1 \leqslant V . r$ & $\Lambda \varepsilon$ & 71.2 & ro & Y .. & IV & $\Lambda . \Lambda$ & 0 & YN \\
\hline دالة & $\because \cdots$ & $\varepsilon V_{.1}$ & $r v \cdot .1$ & $10 \leqslant$ & $0 . r$ & $r$ & 19.4 & 11 & $V 0 . \varepsilon$ & $\varepsilon r$ & rq \\
\hline دالة & $\because \cdots$ & $\sum 9 . r$ & rVI.9 & 100 & 1.1 & $T$ & $r \leqslant .7$ & $1 \varepsilon$ & $v^{\prime r . V}$ & $\varepsilon r$ & $r$. \\
\hline دالة & $\because \cdots$ & V.V & $r \neg \Lambda . \varepsilon$ & 104 & . & . & 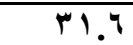 & 11 & $71 . \varepsilon$ & $r q$ & $\mu_{1}$ \\
\hline دالة & $\because \cdots$ & $\varepsilon 9 . r$ & TVY.T & 107 & 1.1 & 1 & YY.A & 14 & $\leqslant 0$ & $\varepsilon r$ & $\overline{r r}$ \\
\hline دالة & $\because \cdots$ & $r \cdot . \varepsilon$ & Y०9.7 & $1 \leqslant 1$ & r.o & r & $r \mu . r$ & 19 & 74.4 & $r q$ & $r \mu$ \\
\hline دالة & $\because \cdots$ & 10.0 & rrA. ${ }^{\prime}$ & $1 \pi 7$ & $\Lambda . \Lambda$ & 0 & $\varepsilon r .9$ & Yo & $\varepsilon V . \varepsilon$ & TV & $r \leq$ \\
\hline
\end{tabular}

من القراءة التحليلية لأرقام الجدول السابق يتضح عدم صحة هذا الفرد فيما يتعلق بجميع العبارات التي تختص ببعد المعوقات التي تحد من التمكين الإداري .

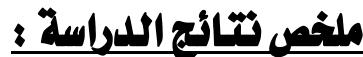

هنـاك مؤثـر عـام يـلدل على عدم الاهتمـام والاكتراث بقيمـة الاسـتبانات والتعامـل معها مـن قبل الجهات التي تمـارس الإدارة خاصـة في مستوي الإدارة الوسطي • ومـن الملاحظ أن كلمـة دالة تعنـي 


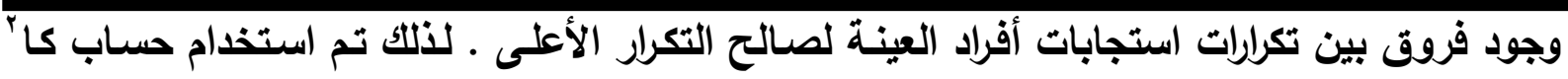
لاراسة الفروق بين التكرارات ويمكن تلخيص نتائج التحليل المتعلقة بأبعاد الاستبانة الأربعة فيما يلي : [1] البعد المعرفي : حيث أسفر التحليل الإحصائي عن عدم صحة الفرد الأول الذي ينص على عدم وجود فروق ذات دلالة إحصائية بين أفراد العينة فيما يتعلق بالجانب المعرفي للتمكين وأبعاده واستراتيجياته وذلك في عبارات عددها ( 11 ) من العبارات الكلية والتي عددها ( ع ا ( ) عبارة حيث جاءت ثُلاث عبارات غير دالة بمعني انه لا توجد فروق فيما يتعلق بهذه العبارات الثثلاث وهذا يتماثسي وني مع صحة الفرد الأول فيما يخص هذه العبارات الثلاث فقط [Y] البعد الثاني المتعلق بالممارسة والتطيق والذي اختصت بـه العبارات المشـار إليها وعددها ) r r r تشير أرقام الجدول عن عدم صحة الفرد الثاني في جميع عبارات هذا البعد مـا عدا خمسـة عبارات فقط من ( r r ) عبارة حيث جاءت ه عبارات غير دالة وهذا يتماشسي مع صحة الفرد الثاني بينما الـ ( V ) عبارة الأخرى لا تحقق صحة الفرد الثاني

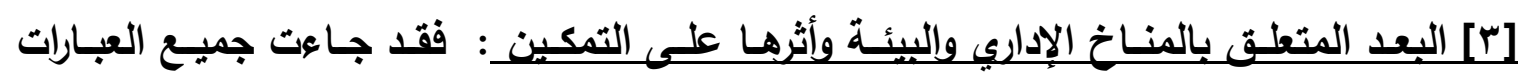
الخاصة بهذا البعد بقيم دالة إحصائيا ما عدا عبارة واحدة رقم ( V ) هي التي تثمشي مع صحة الفرد الثالث بينما باقي العبارات وعددها ثمانية لا تحقق صحة هذا الفرد [ع ] فيما يتعلق بالبعد الرابيع المتعلق بالمعوقات التي تحد من التمكين الإداري_يلاحظ من الجدول أن جميع العبارات جاءت قيمها دالة بما لا يحقق صحة الفرد الرابع الذي ينص على انه لا توجد فروق دالة بين تكرارات استجابات أفراد العينة على عبارات بعد المعوقات التي تحد من التمكين

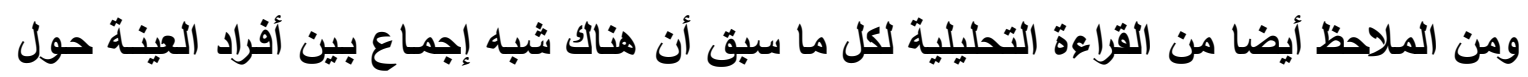

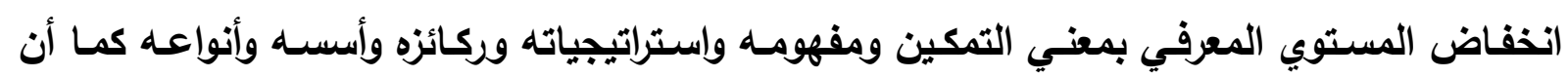
هناك أيضا شبه إجماع على ضعف عملية التمكين بكل أبعادها . يلاحظ شبه اتفاق من معظم أفراد العينة على اثر البيئة والمناخ الإداري على ممارسة عملية التمكين . وهناك أيضا إقرار وإجماع من أفراد العينة حول التسليم بوجود الكثير من معوقات التمكين الإداري والتقويض وخلاصـة القـول أن التمكين الإداري والتفـويض والتلامركزيـة مازالـت مطلبـا بعيـ المنـال وصـعب التحقيق بالشكل المطلوب في واقع ممارسة العمليات الإدارية في الإدارة الوسطي للتعليم في مصر وهذا مجمل ما أسفرت عنه المعالجات النظرية والمستح الميداني لعينة الدراسة وتحليل آرائها . 


\section{أهم المقتزحاتوالتوصيات ؛}

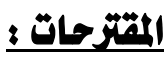

أهميـة توجـه المجتمـع ككل نحـو تطبيـق الأسـاليب الحديثة مـن الشـفافية والمسـاعلة والكفـاءة والمحاسبية ، واعتماد المنهج العلمي واستخدام الممارسات الايمقراطية للنهوض بالمجتمع ككل ، وهذا بلوره ينعكس على المنظومات الفرعية ومنها منظومة التعليم وإدارته استنادا إلي النتائج السابقة يمكن طرح المقترحات التالية لمواجهة ضعف مستوي التمكين الإداري في مدارس التعليم العام في مصر وتثمثيل فيما يلي : - - ضرورة التوصيف الوظيفي الدقيق لكل مستويات العمل الإداري داخل منظومة التعليم - حتميـة الارتفاع والارتقاء بمستوي مديري المدارس ومن هم في مستوي الإدارة العليا والمتوسطة وتزويدهم بالجديد فيما يتعلق بالنظريات الإداريـة الحديثة ومنظومـة القرارات ونظريـات اتخاذ القرار وطرق وأساليب اتخاذ وصنع وتقييم القرار ، وذلك من خـلال إضـافة مقررات دراسية بكليات إعداد المعلم تعالج هذه الموضوعات ، وإقامة دورات تدريبية فعالة يارس بها المتخصصون هذه المقررات بجدية واستمرارية . - ضرورة تحسين أحوال المعلم المادية والاجتماعية ورفع مكانته الأدبية داخل المجتمع بما ينعكس على ارتفاع أدائه وأداء المدارس بشكل عام • - تعيين وترقية مديري المدارس بناعا على الكفاءة وليس معيار الأقدمية المطلقة . - زيـادة الـوعي بـادوار كل وظيفـة إداريـة وذلك عن طريق زيـادة الفاعليـات مـن نـدوات ومحاضـرات ومـؤتمرات وورش عمـل ومطبوعـات تسـهم في توسـيع القاعدة المعرفيـة بـادوار ومهـام وحقـوق وواجبات كل من يشغل وظيفة محددة داخل منظومة إدارة التعليم • - أهمية تفعيل دور نقابة المعلمين وتحقيق التواصل بينها ويبن وزارة التعليم ومراكز البحوث المعنية بالتربية والإدارة وتكنولوجيا المعلومات وغيرها لتحقيق التطوير الإداري والتعرف على اتجاهات الفكر المعاصر من قبل العاملين في منظومة التعليم - تثـيع إجراء الدراسـات التقويميـة و الميدانيـة على مؤسسـات التعليم في كافـة جوانبها وخاصـة

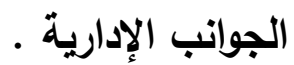

- حتمية التحرر من سلبيات الماضي والروتينية القاتلـة في ممارسـة العمل الإداري خاصـة في مجال الإدارة الوسطي في التعليم وإتاحة مسـاحة أوسـع لمديري الإدارات التعليميـة ومـديري المدارس في المشاركة في صنع واتخاذ القرارات اليومية - ضرورة تحديث القوانين والتشريعات المتعلقة بالتعليم وإدارته في كافة المستويات - التأكيد على روح الفريق و تثجيع العمل ال جماعي 


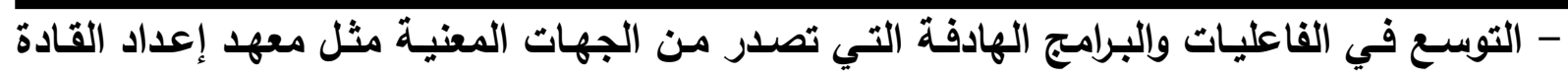

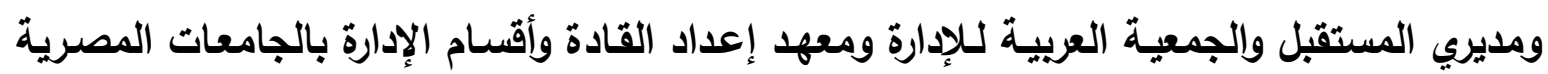

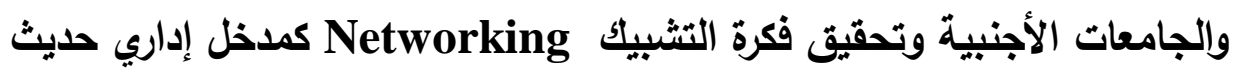
- العمل على ابتكار آليات حديثة ومبتكرة لجسر الفجوة بين من يقومون بالعمل التنفيذي ومن يهتمون بالعمل الأكاديمي التظيري الفكري

التوصياتة

يمكن طرح التوصيات التالية والتي يوصي بها الباحث في ضوء نتائج الدراسة الراهنة. وتتمثل في:

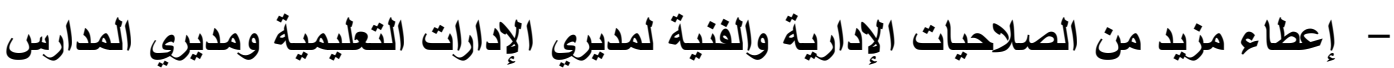

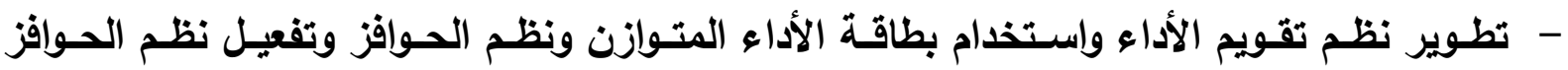

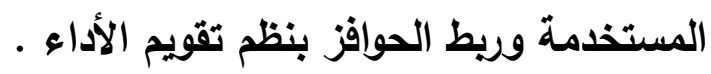

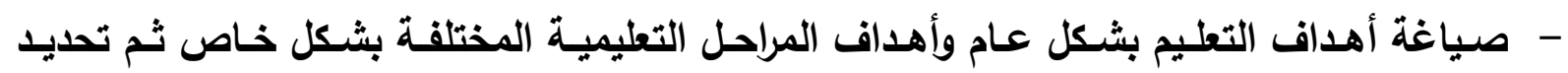
وصياغة أهداف المقررات والبرامج والمواد الدراسية حتي يتمكن مديري الإدارات من اتخاذ القرارات الإدارية الصائبة المتعلقة بتحقيق تلك الأهداف .

- التوجه الفوري نحو العمل الجماعي وتعزيز روح الفريق والالتزام بالجودة والدقة والثقة المتبادلة

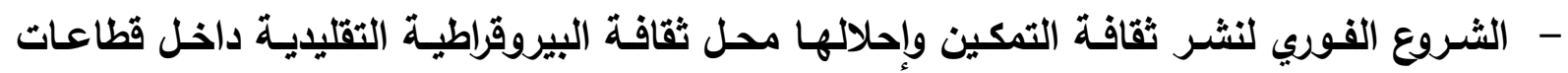
التعليم المختلفة - تثجيع التفاعل بين مديري الإدارات داخل مصر وخارج مصر للاستفادة من التجارب الدولية في مجال تطوير إدارة التعليم - الاعتماد على مكافآت التميز وحوافز الجودة وغيرها من الممارسـات التي ترفع مستوي الأداء في العمل الإداري - إعـادة هيكلة البنيـة الإداريـة لمنظومـة التعليم باستخدام أسـاليب إعادة هندسـة العمليـات الإداريـة لتحقيق بناء تنظيمي مرن لمنظومة التعليم المصري في كافة مستوياتها

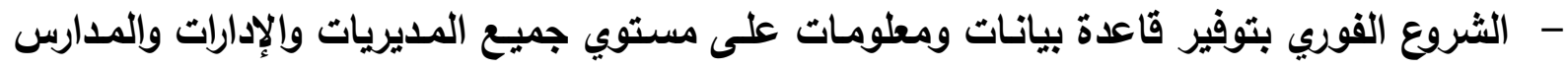
بثكل يسهل صناعة واتخاذ القرار المناسب

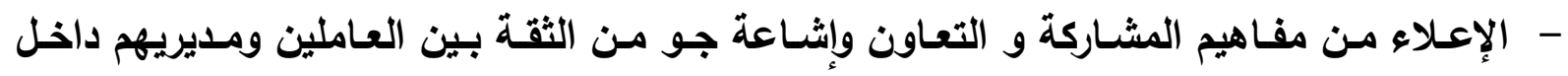

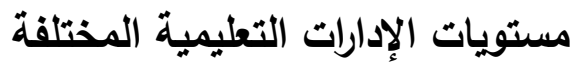
- ضرورة إنثاء مراكز خاصة بكل محافظة لإعداد وتدريب القادة الإداريين في المدارس الإدات - ضرورة إعطاء صلاحيات حقيقية وفعلية لإدارة المدرسة 


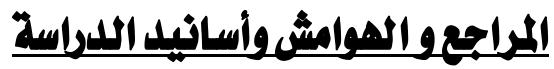

[1] راجع عبد الصد الاغبري : الإدارة المدرسية ، البعد التخطيطي و التظظيمي المعاصر بيروت ، دار

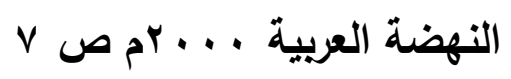

[؟] انظر عبد الباري الطاهر وعبد العزيز مززوق : تمكين العاملين مدخل لتحسين أزمات الحج دراسـة

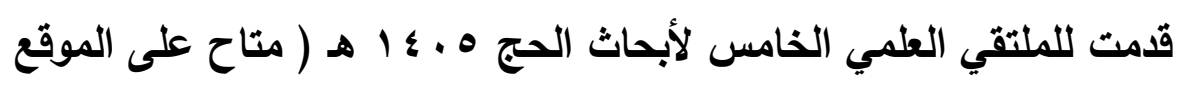

www.elmanshawi.com, other/ altehar.com

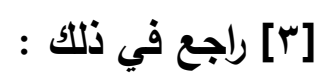

عطية أفندي : تمكين العاملين ، مدخل للتحسين والتطوير المستمر ، القاهرة ، المنظمة العربية للتنمية

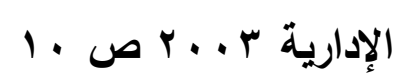

*منيرة جعلان على العزم : التمكين الإداري في دولـة الكويت وإبرز معوقاته في ضوء الفكر الإداري

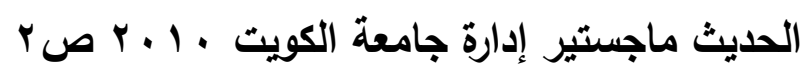

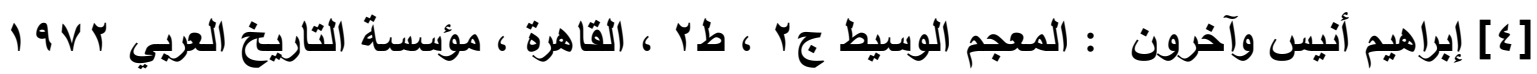

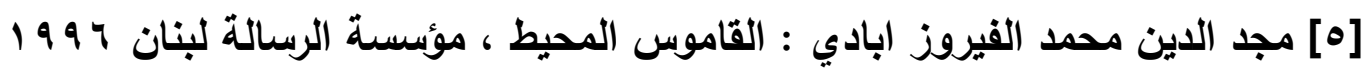

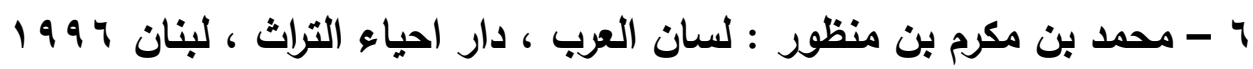

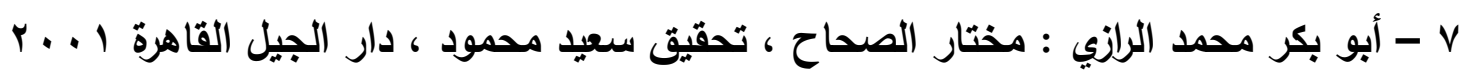

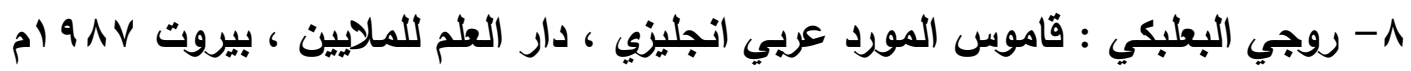

१- Conger , j,and Kamango , ; the empowerment process , integrating theary and practice $t$, academy of homagement review, 13, 32,1988

10- Bowen almmaler : The empowerment of service workers what why, how are when sloan management review , $\mathbf{N 3 3}, 1992$,

1 - 1 منيرة جعيلان على العزمي : التمكين الإداري للدي مديري مدارس التعليم العام في دولية الكويت

$$
\text { مرجع سابق ، ص } 9
$$

r ا - استندت منيرة جعيلان في ذلك إلي تمارا اليعقوب : ثقة الموظف في المدير ودورها في التمكين في القطاع الحكومي - رسـالة ماجستير غير منشـورة جامعة اليرومسوك كلية الاقتصساد والعلوم

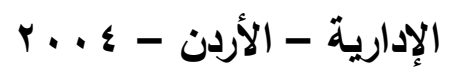

rا - مي خميس شفيق محمد : تمكين العاملين وامكانيه تطبيقه في مؤسسات التعليم قبل الجامعي

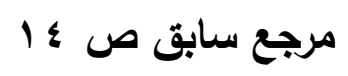

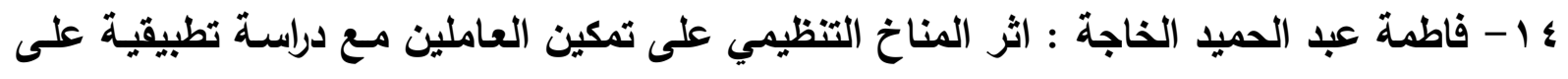
خبرة الحكومة الاتحادية بدولة الإمارات العربية - رسالة دكتوراة - كلية الاقتصاد والعلوم السياسية التمبية

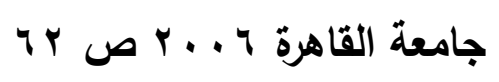

ه - محمود أبو النور عبد الرسول : تمكين المديرين كمدخل لانضباط المدرسة الثانويـة في مصر

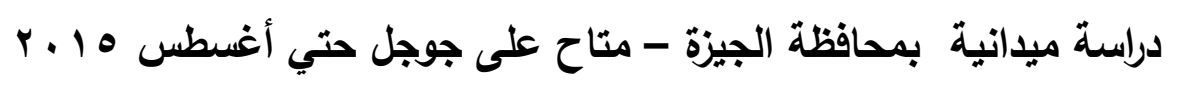




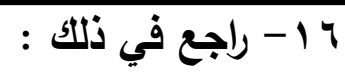

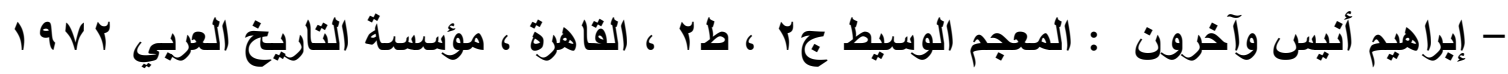

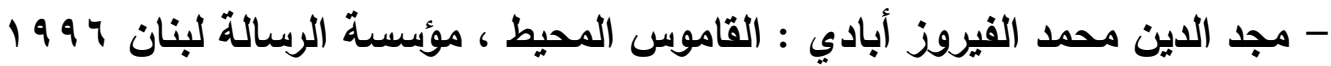
- محمد بن مكرم بن منظور : لسان العرب ، دار إحياء التراث ، لبنان 1999

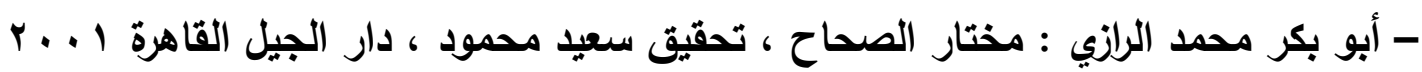

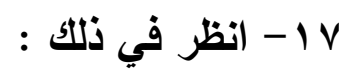

- منير البعلبكي : قاموس المورد انجليزي - عربي دار العلم للملايين بيروت . 191

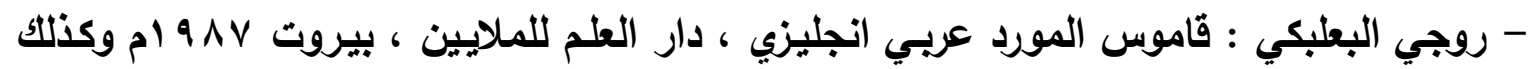
- ق قاموس الدليل

-Conger, $\mathbf{j}$, and Kamango , ; the empowerment process , integrating theory and practice $t$, academy of homagement review,

- Bowen almmaler: The empowerment of service workers what why, how are when Sloan management review.

1 ا - شـاكر محمد فتحي احمد: إصـلاح الإدارة التعليمية في مصر في ضسو مقومـات الفكر الإداري

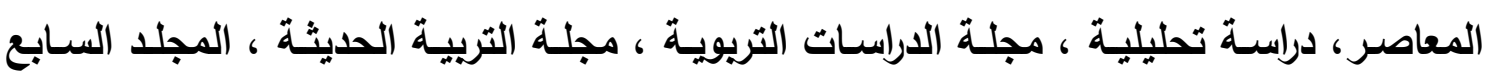

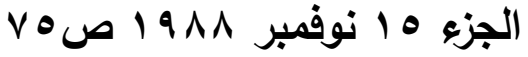

$$
\begin{aligned}
& 9 \text { ا } 19
\end{aligned}
$$

- أبو بكر محمد الرازي : مختار الصحاح ، تحقيق سعيد محمود ، دار الجيل القاهرة ب...

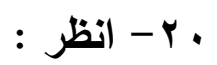

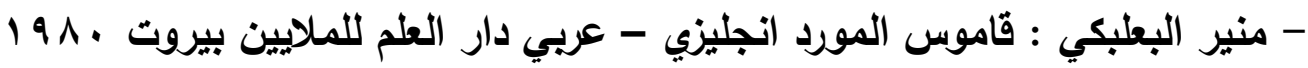

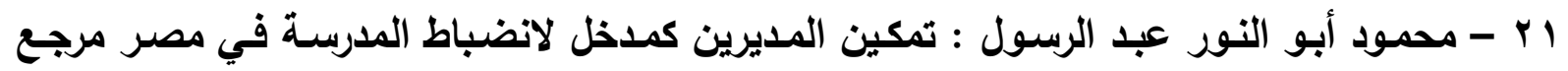

سابق

r r - مضاوي الشعلان وسهام كعكي : آليات تفعيل التمكين لتحقيق جودة الأداء مرجع سابق

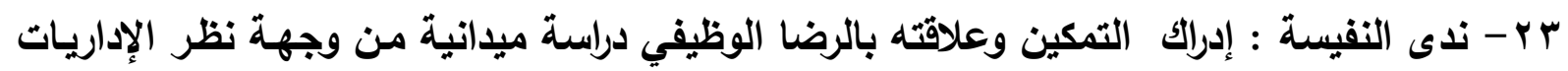

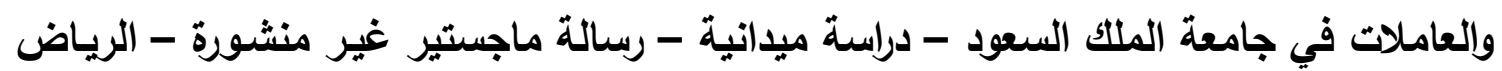

$$
\text { r. } 11 \text {. }
$$

§ Y - مي خميس شفيق محمد : تمكين العاملين وإمكانية تطبقه في مؤسسات التعليم قبل الجامعي مرجع سابق. - مين.

ه - أبو بكر أبو سـالم : اثر تمكين العاملين في الولاء التنظيمي للاي العاملين في شركة سونتر

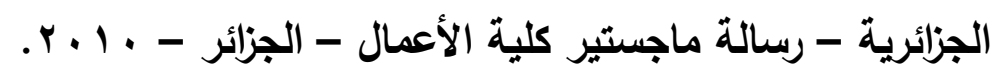

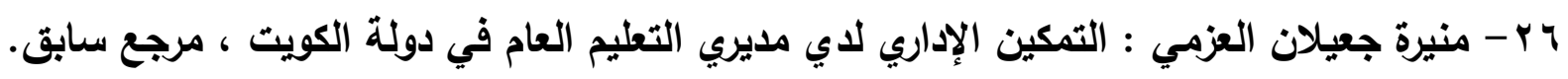




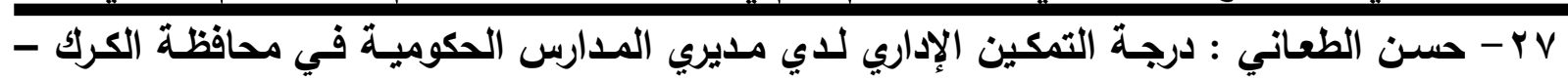

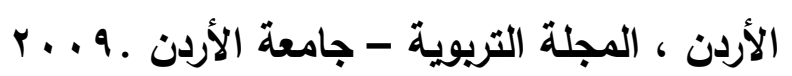

^r - أثثر عبد الأمير ، وحسين عبد الرسول :إستراتيجية التمكين وأثرها في فاعلية فريق العمل ،

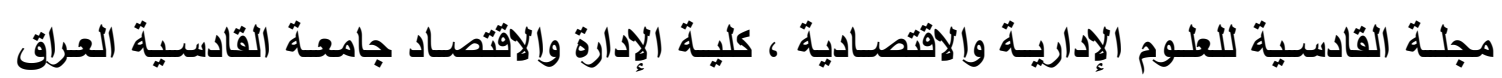
r. . $\Lambda$.

q - عوض العنزي ومحمد القريوتي : الشعور بالتمكين لاي المديرين من مستوي الإدارة الوسطي في دولة الكويت ، دراسة ميدانية ، مجلة جامعة دمشق للعلوم الاقتصادية والقاتونية ج ـ . . .

r . - Emerson : why employee empowerment should be more than just abuzz word at your ca gait

r - Prawit, Erawan; teacher empowerment and developing acicular impartment system in municipal schools using cooperation between university and musicality in Thailand, Asia pacific No2, 2008

r r- J, Solazer ; $t$ he relation ship between employee empowerment, over all job satisfactory and organization commitment, study of Vacuumed university of soften Alabama, 2008

rr- Lambert, Raricia faculty perceptions of empowerment, Joh. satisfaction, and commitment to organization three indirect universities of miscour Columbia , 2007.

r \& - R bogler and A, somech ; mfluence of teacher empowerment on teaches organizational commitment, u organizational citizenship behavior in schools teaching and teacher education 20,2004

ro- Jadesenome; the barrier of conflict with superiors in the relationship between employee empowerment and organization and commitment work and sores , $18,11,2004$

r- Mcarthur; Numerate and leadership and faculty empowerment at the community, community college review 30,2002

$r \vee$ - E,mak and beyond ; relation ship between organizational climate and empowerment of nurses in Hong Kong, journo of nurse management $10,3,2002$.

r^- T, kellari and F, dancewear and ; leadership and empowerment asocial exchange prospective human relations $48,1995$.

r q- D, clooins; rooting for empowerment empower mention in organization $, 3,2,1995$.

\&.- G.G dutty ; professional development and the disempowerment of teacher and professors schools phidelta kappa 75,1994 
§ - K.W , Thomas and B.A velthouse cognitive elements of empowerment, an interpretive model of intrinsic task inotivaticis, academy of management review 15, 1990.

$$
\text { : (نظ }
$$

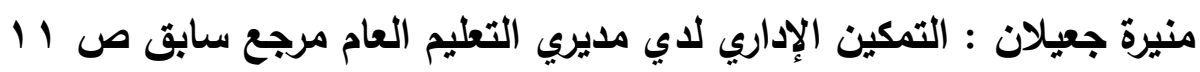
ب آ ـ - المرجع السابق نفس الصفحة. ؟ ؛ - احمد الثهري : دراسات في ضوء القران الكريم ، عوامل النصر والتمكين في دعوات المرسلين ،

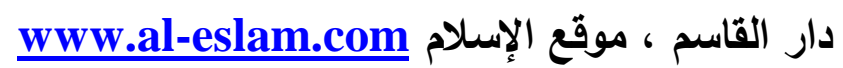

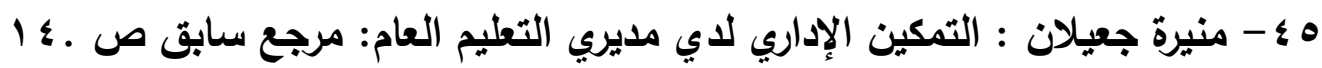

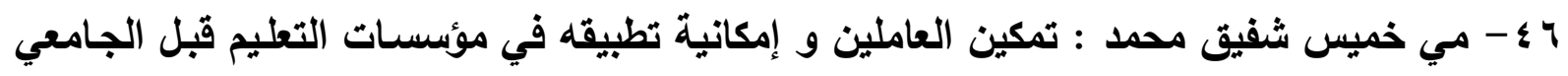

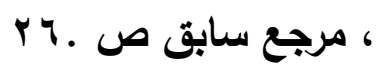

Vـ - مضاوي بنت محمد الشعلان وسهام بنت محمد كعكي : آليات تفعيل التمكين لتحقيق جودة الأداء في جامعة الأميرة نورا بنت عبد الرحمن - المجلة السعودية للتعليم العالي العدد العاثشر محرم

$$
\text { \& . }
$$

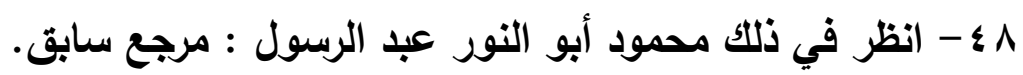

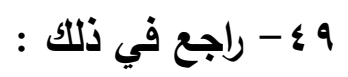

- عبد المحسن القحطاني وآخرون : مدي تطبيق مبادئ كايذن للتطوير المستمر في إدارات المناطق

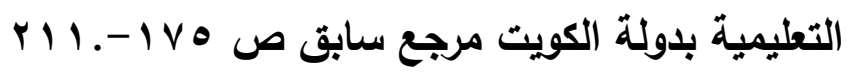

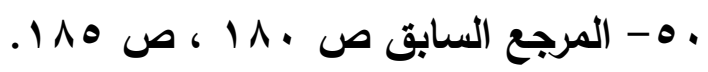

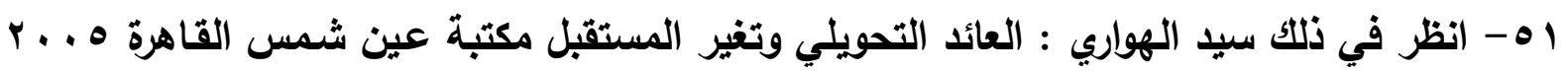
. ro ص מ

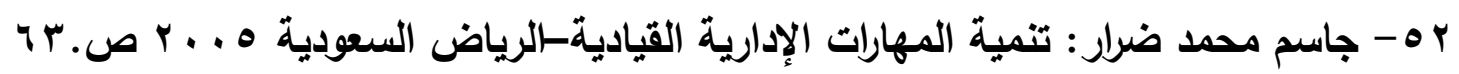
or- Rikreinter and A.Kincki ; organizational and behavior rewind,2009p.p23-27.

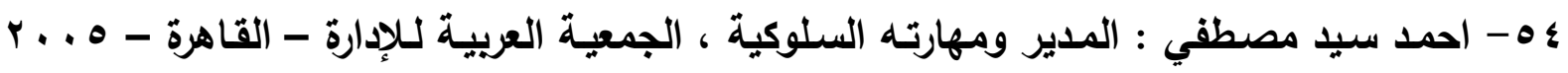

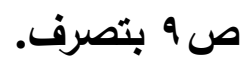

هـ - محمود أبو النور عبد الرسول : تمكين المديرين كمدخل للانضباط المدرسي في مصر مرجع

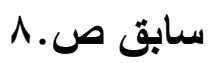

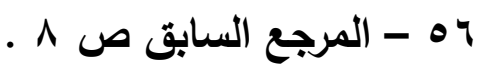
: OV 


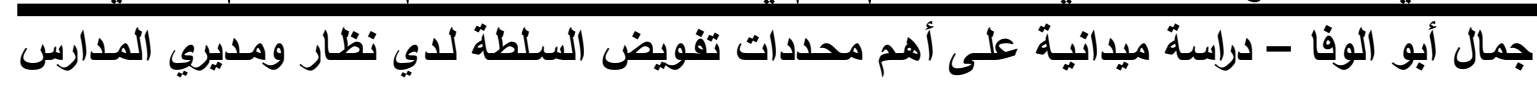

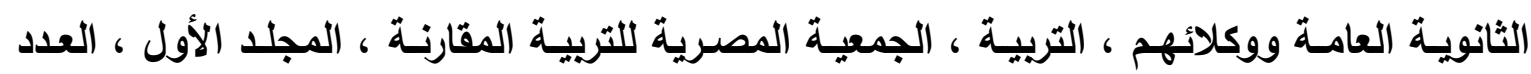

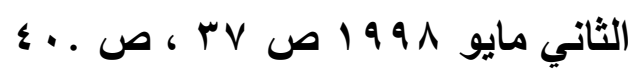

^هـ - منيرة الجعيلان : التمكين الإداري لدي مديري مدارس التعليم العام في دولة الكويت - مرجع

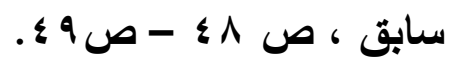

$$
\begin{aligned}
& \text { 9ه - المرجع السابق صو ، ص ، · r بتصرف. }
\end{aligned}
$$

• 1 - مي خميس شفيق : تمكين العاملين وإمكاتية تطبيقه في مؤسسات التعليم قبل الجامعي - مرجـع

$$
\text { سابق ص. • }
$$

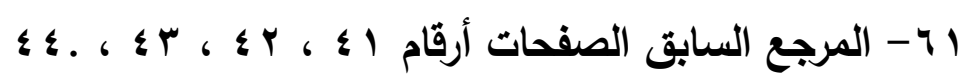

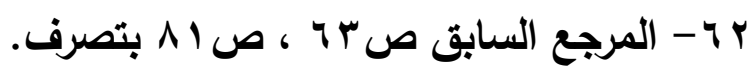

ب - منيرة جعيلان على العزمي : التمكين الإداري لدي مديري مدارس التعليم العام في دولة الكويت -

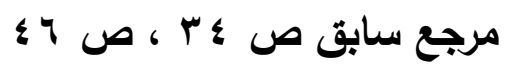

ء 1 - جمال أبو الوفا : دراسة ميدانية للتعرف على أهم محددات تفويض السلطة لدي نظار مدارس ،

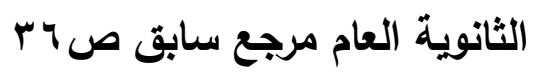

ه 1 - محمود أبو النور أبو الرسول : تمكين المديرين للانضباط في مصر مرجع سابق ص r I ، ص

צ - - مي خميس شفيق : تمكين العاملين وإمكانية تطبيقه في مؤسسـات التعليم قبل الجامعي مرجح

$$
\begin{aligned}
& \text { سابق ص .0 ؛ } \\
& \text { Vף - المرجع السابق ص rه }
\end{aligned}
$$

1 - هذا ما أورده خالا حنفي ( محرر ) : أي دور للثبكات في تغيير عالمنا ؟ ، اتجاهات نظرية في تحليل السياسة الدولية ، الثبكات مداخل بناء القوة في القرن الواحد والعشرين ، ملحق مجلة

$$
\text { السياسة الدولية أكتوير } 10 \text {. ب. }
$$

9 9 - المرجع السابق صع ، حيث ذكر المصدر الأساسي وهو

Peter Rlastyic and john cleuelimd, made and eine Taylor, connecting to change, the world harnessing the poor of the networks farcical impact London 2014, p 1-11

$$
\text { : هذا ما ذكره خالا حنفي مستندا إلي - v . }
$$

Ricard, Wilson grave and Martha nonez: evaluating international social change networks accentual http; www.mange .co.uk

Y - خالا حنفي،الثبكات- مداخل بناء القوة في القرن الواحد والعشرين ، مرجع سابق ، ص.ب V - المرجع السابق نفس الصفحة. Vr

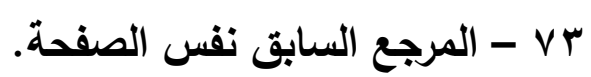




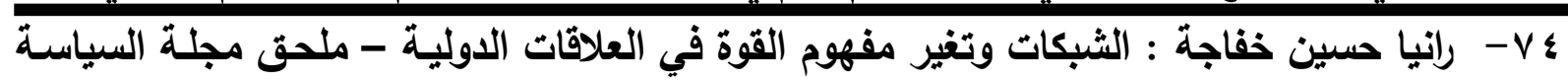

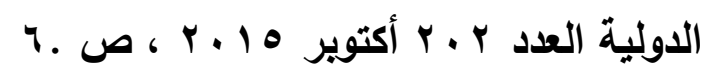

P - V - المرجع السابق نفس الصفحة.

TV - منيرة جعيلان العزمي : التمكين الإداري لدي مديري مدارس التعليم العام مرجع سابق ص. 9

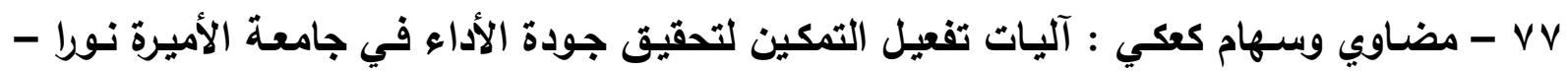

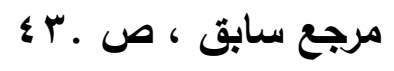

- میيرة جعيلان العزمي : التمكين الإداري لدي مديري التعليم العام في دولة الكويت مرجع سابق

ص.

Vq - مي خميس شفيق : تمكين العاملين في مؤسسات التعليم قبل الجامعي مرجع سابق ص سبr هذا وقث رجعت مي خميس في ذلك إلي :

Gretchen Seritzer - toward the perspectives, a review of social , stkoctokal and psychological empowerment network , universal ,1977.

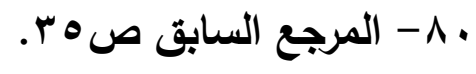

ا1 - منيرة جعيلان العزمي : التمكين الإداري لاي مدارس التعليم العام في دول الكويت مرجع سابق

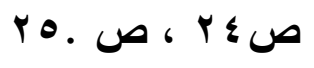

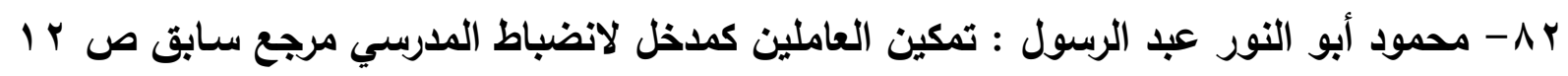

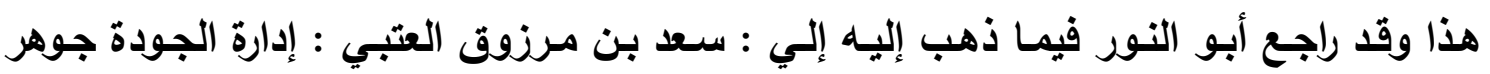

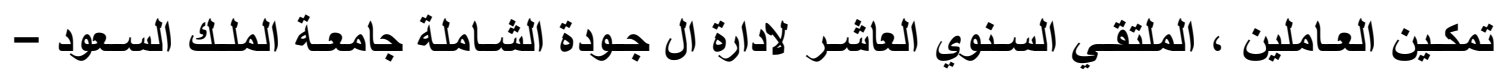

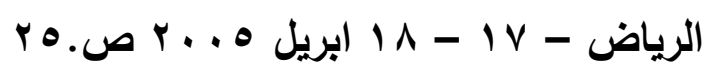

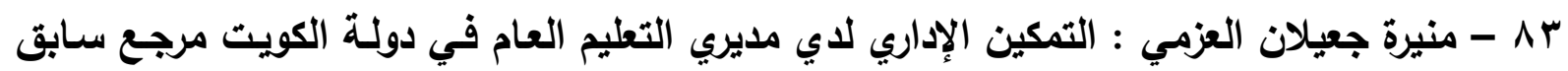

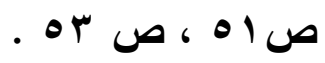

؟ 1 - مضاوي الثعلان وسهام كعكي : آليات تفعيل التمكين لتحقيق جودة الأداء في جامعة الأميرة

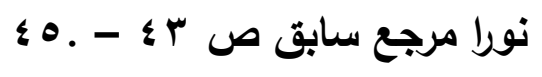

هـ- منيرة جعيلان العزمي : التمكين الإداري لاي مديري التعليم العام في الكويت مرجع سابق ص لـات $. r \mu-r$ 